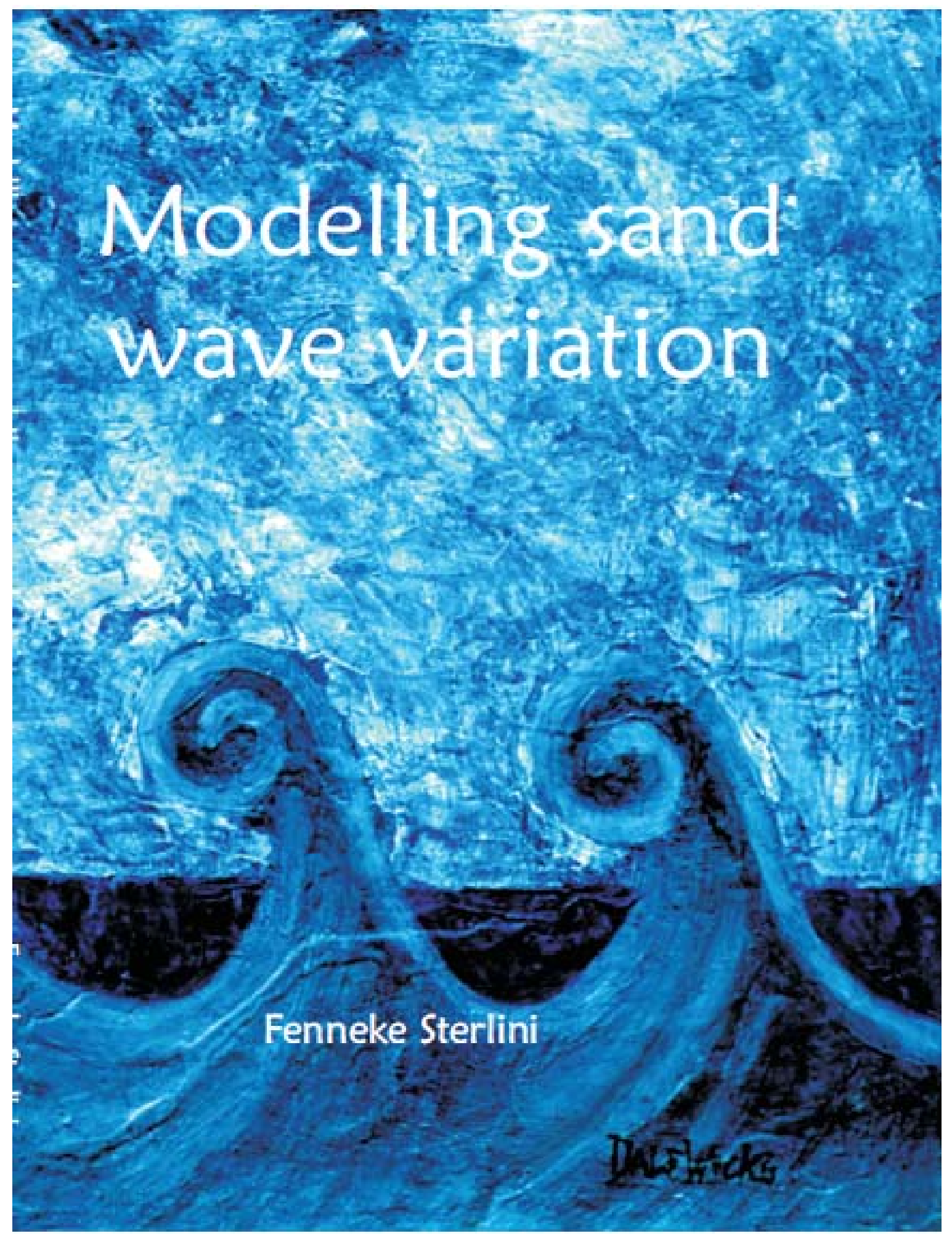


Modelling Sand Wave Variation 
Promotion committee:

prof. dr. F. Eising

prof. dr. S.J.M.H. Hulscher

dr. D.M. Hanes

dr. T.A.G.P. van Dijk

prof. N. Dodd

prof. dr. ir. H. Ridderinkhof

dr. ir. C.M. Dohmen-Janssen

prof. dr. ir. H.W.M. Hoeijmakers

ir. R. Bijker
Universiteit Twente, chairman and secretary Universiteit Twente, promotor

USGS Pacific Science Center

Universiteit Twente and Deltares

Nottingham University

Universiteit Utrecht and NIOZ

Universiteit Twente

Universiteit Twente

ACRB

This research is supported by:

- The Technology Foundation STW, applied science division of NWO and the technology programme of the Ministry of Economic Affairs

- EncoraNL,

their support is gratefully acknowledged.

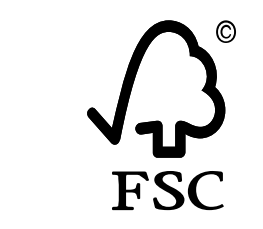

Mixed Sources

Product group from well-managed
forests, controlled sources and

recycled wood or fibre

Cert no. CU-COC-811465

www.fsc.org

(c) 1996 Forest Stewardship Council

Cover: 'waves' by Dale Wicks, (c) 2009.

Copyright (C) 2009 by Fenneke Sterlini, Enschede, The Netherlands

Printed by Gildeprint, Enschede, The Netherlands

ISBN 978-90-365-2851-1 


\title{
Modelling Sand Wave Variation
}

\author{
Proefschrift
}

ter verkrijging van

de graad van doctor aan de Universiteit Twente, op gezag van de rector magnificus, prof. dr. H. Brinksma, volgens besluit van het College van Promoties in het openbaar te verdedigen

op vrijdag 12 juni om 16:45

door

Fenna Margreet Sterlini - van der Meer geboren op 26 juli 1980 te Velp 
Dit proefschrift is goedgekeurd door de promotor: prof. dr. S.J.M.H. Hulscher 


\section{Contents}

$\begin{array}{ll}\text { Voorwoord } & 1\end{array}$

$\begin{array}{ll}\text { Summary } & 3\end{array}$

$\begin{array}{ll}\text { Samenvatting } & 7\end{array}$

1 Introduction $\quad 11$

1.1 Sand Waves . . . . . . . . . . . . . . . . . . . . . 11

1.2 Human Interaction . . . . . . . . . . . . . . . . . . . 12

1.3 Sand Wave Observations . . . . . . . . . . . . . . . . . . . 14

1.4 Sand Wave Modelling . . . . . . . . . . . . . . . . . 15

1.5 Research Questions . . . . . . . . . . . . . . . . . . . . 17

1.6 Thesis Outline ....................... 18

2 Simulating and understanding sand wave variation, $\begin{array}{lr}\text { a case study of the Golden Gate sand waves } & 19\end{array}$

2.1 Introduction . . . . . . . . . . . . . . . . . . . . . 19

2.2 Measurements . . . . . . . . . . . . . . . . . . 21

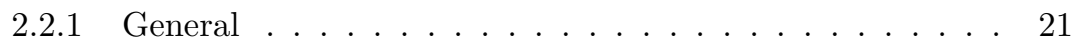

2.2 .2 Transects . . . . . . . . . . . . . . 22

2.3 Sand Wave Code . . . . . . . . . . . . . . . . . . . . . 24

2.3.1 Sand Wave Theory . . . . . . . . . . . . . 25

2.3.2 Physical and Numerical Background . . . . . . . . . . 27

2.4 Results . . . . . . . . . . . . . . . . . . . . 29

2.4.1 Symmetric Forcing . . . . . . . . . . . . . . 30

2.4.2 Asymmetric Forcing . . . . . . . . . . . . . . . 32

2.4.3 Sensitivity Analysis . . . . . . . . . . . . . . . 37

2.4.4 Random Initial Bed Perturbation . . . . . . . . . . . . . . 38

2.5 Discussion . . . . . . . . . . . . . . . . . . . . . . . . . . . . . . . . .

2.6 Conclusions . . . . . . . . . . . . . . . . . . 42

3 Modelling the effect of surface waves on offshore sand waves $\mathbf{4 3}$

3.1 Introduction . . . . . . . . . . . . . . . . . . . . 43

3.1.1 Sea Bed Sand Waves . . . . . . . . . . . . . . . . 43

3.1.2 Surface Waves . . . . . . . . . . . . . . . . . . 43

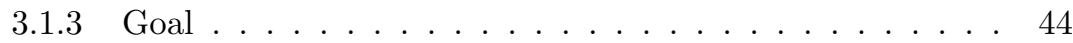

3.2 Model Approach . . . . . . . . . . . . . . . . . . . 45 
3.2 .1 Sand Wave Model . . . . . . . . . . . . . . . . . . . . 45

3.2 .2 Surface Waves . . . . . . . . . . . . . . . . . 47

3.3 Results . . . . . . . . . . . . . . . . . . . . . . . 48 48

3.3.1 Including Surface Waves . . . . . . . . . . . . . . 48

3.3 .2 Storm Periods . . . . . . . . . . . . . . . . . . . 52

3.3.3 Comparison With Field Data . . . . . . . . . . . 54

3.4 Discussion . . . . . . . . . . . . . . . . 56

3.4 .1 Physical Interpretation . . . . . . . . . . . . . . 56

3.4 .2 Model Simplifications . . . . . . . . . . . . . . . . . . . . 59

3.5 Conclusions . . . . . . . . . . . . . . . . . . 61

4 Exploring suspended sediment transport effects on sand waves: a model study $\quad 63$

4.1 Introduction . . . . . . . . . . . . . . . . . . 63

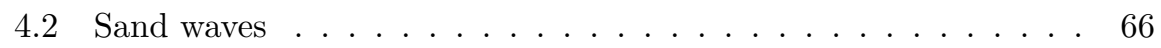

4.2 .1 Sand wave theory . . . . . . . . . . . 66

4.2 .2 Sand wave characteristics . . . . . . . . . . 66

4.3 Sand wave model . . . . . . . . . . . . . . . . 67

4.3.1 Sediment diffusivity model . . . . . . . . . . . . 71

4.4 Model results . . . . . . . . . . . . . . . . . . . . . . . 72

4.4 .1 Model parameters . . . . . . . . . . . . . . . 72

4.4 .2 Model sensitivity . . . . . . . . . . . . . . . . . . . . 74

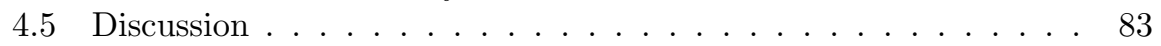

4.5.1 Model results . . . . . . . . . . . . . . . . . . 83

4.5.2 Sediment concentrations . . . . . . . . . . . . . . 85

4.5 .3 Uncertainties . . . . . . . . . . . . . . . . . . . 86

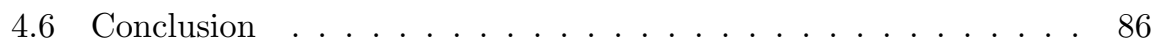

5 Modelling grain size sorting during offshore $\begin{array}{lr}\text { sand wave evolution } & 89\end{array}$

5.1 Introduction . . . . . . . . . . . . . . . . . . . . . . 89

5.2 Observations from the North Sea . . . . . . . . . . . . . 91

5.2 .1 Data Collection and Processing . . . . . . . . . . . . 91

5.2 .2 Site-Specific Characteristics . . . . . . . . . . . . . . . 91

5.2.3 Conclusions on Observed Sorting Patterns . . . . . . . . . 93

5.3 Morphodynamic Model . . . . . . . . . . . . . . . . . . . . . 94

5.3 .1 Geometry . . . . . . . . . . . . . . . . . 94

5.3.2 Hydrodynamics and Solution Method . . . . . . . . . 94

5.3.3 Sediment, Active Layer and Bed Evolution . . . . . . . . 95

5.3.4 Fractional Sediment Transport . . . . . . . . . . . . . 96

5.3.5 Solution Procedure . . . . . . . . . . . . . . . . . . 97

5.4 Results . . . . . . . . . . . . . . . . . . . . . . . 97 97

5.4 .1 Overview of Simulations . . . . . . . . . . . . . 97

5.4.2 Simulation with a Bimodal Mixture . . . . . . . . . . 97

5.4.3 Simulation with Uniform Sediment . . . . . . . . . . . . . 99

5.4.4 Sensitivity to Sediment Composition . . . . . . . . . . . 99 
5.4.5 Sensitivity to Environment _ . . . . . . . . . . . . 99

5.5 Discussion . . . . . . . . . . . . . . . . . . 100

5.5.1 Grain Sorting in the Model Results . . . . . . . . . . 100

5.5.2 Active Layer Thickness, Hiding-Exposure and Bimodal Mixture . . . . . . . . . . . . . . . . . . . 102

5.5.3 Comparison to Observations . . . . . . . . . . . . . . . 103

5.6 Conclusions . . . . . . . . . . . . . . . . . . . . . . . . 104

6 Discussion 105

6.1 Model Approach . . . . . . . . . . . . . . . . . . . 105

6.1.1 Linear versus Non-Linear Modelling . . . . . . . . . . . 105

6.1.2 Data Based versus Process Based Modelling . . . . . . . . 106

6.1.3 Idealized versus Full/Complex Modelling . . . . . . . . 107

6.2 SWC Results and Further . . . . . . . . . . . . . . . . . . . . 109

6.2 .1 General Results . . . . . . . . . . . . . . . . . . . . 109

6.2 .2 Combination of Processes . . . . . . . . . . . . . . . . 110

6.2 .3 Model Drawbacks . . . . . . . . . . . . . . . . . . . 112

$\begin{array}{lll}7 \text { Conclusion } & 117\end{array}$

7.1 Model Predictions . . . . . . . . . . . . . . . . . . . . 117

$7.2 \quad$ Physical Processes . . . . . . . . . . . . . . . . . . . . . . 118

7.2 .1 Suspended Sediment . . . . . . . . . . . . . . . 118

7.2 .2 Surface Waves . . . . . . . . . . . . . . . . . . . . 118

7.2 .3 Grain Mixtures . . . . . . . . . . . . . . . . . . . 118

7.3 Recommendations . . . . . . . . . . . . . . . . . . . . 119

$\begin{array}{ll}\text { Bibliography } & 121\end{array}$

$\begin{array}{lr}\text { About the author } & 127\end{array}$ 



\section{Voorwoord}

Het boekje dat nu voor $\mathrm{u}$ ligt is het resultaat van een aantal jaren werk. In deze periode, van 2004 tot 2009, heb ik de verschillende fasen van een AIO doorgemaakt, en hebben veel mensen bijgedragen aan het voltooien van dit project.

Toen ik in september 2004 in Twente begon had ik nog niet het flauwste benul van de zandgolvenwereld waarin ik zou gaan verkeren. Mijn eerste kader werd al snel geschetst door Attila Németh die mij het eerste half jaar begeleide. Nadat ik was overgestapt op de code (code! niet model) van Joris van der Berg werd hij voor een lange tijd mijn vraagbaak. Het regelmatige buurten leverde bij mij nogal eens het gevoel op dat ik er nooit iets van zou gaan begrijpen, maar dankzij Joris' geduld en creativiteit in het bedenken van voorbeelden werd ik toch steeds verder ingewijd in het programmeren en modelleren.

De overgang naar de tweede fase, van langzaam groeiend overzicht, werd versneld door het afstudeertraject van Irene Wientjes. Tijdens deze plezierige samenwerking, hebben we beiden veel geleerd.

Tijdens de eerste fase, maar zeker daarna was Suzanne Hulscher mijn vaste referentiepunt in de zandgolvenwereld. Niet alleen inhoudelijk maar ook voor het proces van promoveren wist ze mij telkens te motiveren en op weg te helpen. En hoe ik me ook verzette tegen 'het buitenland' waar ik vooral niet teveel heen wilde, Suzanne wist me telkens te strikken voor trips...Uiteindelijk met veel goede resultaten!

In de lente van 2007 vertrok ik naar Santa Cruz (USA) om samen te werken met de USGS om vervolgens door te vliegen naar een zomerschool in Spanje en in de herfst voor een paar maanden naar de Universiteit van Nottingham te vertrekken. In deze fase van het AIO zijn, kwam ook eindelijk het gevoel dat ik de stof overzag en wist waar ik naar toe werkte.

It was great pleasure to collaborate with both the USGS and the University of Nottingham. Dan and Nick thank you both so much for your help with and interest in my work. Edwin, $\mathrm{Li}$ and both their families made my stay in Santa Cruz more than worth the far distance. Also I would like to thank Julia and Meinaert for all the good times in Nottingham!

En zo kon in 2008 de laatste fase van start gaan: doen wat je eigenlijk al veel eerder had moeten doen. En dan schrijven en herschrijven en opnieuw schrijven en het anders opschrijven en... Uiteindelijk ligt er dan opeens een boekje.

Sociaal gezien heb ik geboft met de WEM afdeling. De lunchwandelingen (weer of geen weer) en de geboorte van de 'appelmomenten' hebben zeker bijgedragen aan mijn motivatie om te werken. Ook de WEM dames etentjes en de 
vakanti...nee,... conferenties en zomerscholen zorgden voor veel gezelligheid.

In het bijzonder wil ik mijn paranimfen Lisette en Henriët bedanken. Niet alleen omdat ze mij tijdens deze laatste loodjes bijstaan, maar ook omdat de afgelopen jaren zonder hun vriendschap veel minder waard was geweest. Henriët en ik zaten al spoedig op één lijn (in een zwembad in Mexico) over het feit dat je werk niet al te serieus moet nemen. Dit leidde er toe dat mensen soms twijfelden aan onze toerekeningsvatbaarheid, maar ook dat weten we wel weer te relativeren. Lisette ontmoette ik een paar maanden later toen ze met haar AIOschap begon in januari 2005 en mijn kamergenoot werd. Voor 8 uur per dag op dezelfde kamer betekende onze levens in voor- en tegenspoed delen, en zeker, ik had me geen betere roomie kunnen wensen.

Naast mijn proefschrift was er echter nog een ander 'resultaat' dat ik nooit verkregen had zonder dit AIOschap en de daarbij behorende conferenties... Ik was de laatste die verwachtte in april 2005 in Barcelona een Engelsman tegen te komen aan wie ik mijn hart volledig zou verliezen. Dat hij vervolgens ook nog eens naar Nederland is gekomen als mijn man... Paul my love, I'm the luckiest woman thanks to you :-)

Tot slot dank ik God, voor al de mogelijkheden die Hij mij heeft gegeven en daarbij ook de kracht om dit alles te voltooien.

Vertrouw op de HEER met heel je hart, steun niet op eigen inzicht.

Denk aan hem bij alles wat je doet, dan baant hij voor jou de weg.

(Spreuken 3:5-7) 


\section{Summary}

The sea floor of shallow seas is rarely flat and often dynamic. Due to the complex interaction between waves, tides and sediment, the bed changes continuously and various bedforms exist. A widely occurring bedform type is the sand wave, for example observed in the North Sea (Van der Veen et al., 2006), the Bisanseto Sea (Knaapen and Hulscher, 2002) and San Francisco Bay (Barnard et al., 2006). Sand waves occur where tidal currents are strong, the water depth is 10 to $55 \mathrm{~m}$ (Bijker et al., 1998) and sand is in good supply. Sand waves form more or less regular wavelike patterns on the seabed with crests up to one third of the water depth and wave lengths of hundreds of metres (McCave, 1971). Migration of sand waves can be in the order of metres up to tens of metres per year.

Because of their migration speed and spatial dimensions, sand waves can interfere with anthropogenic activities, such as shipping lanes, pipelines and cables, and wind farms. In relation to offshore activities, not only are the mean characteristics of sand waves important, but especially the variation and extremes in both space and time. These variations can be caused by variation in environmental factors, such as tidal flow, sediment characteristics, surface waves, storm seasons and water depth.

As the effects of these environmental factors are difficult to separate in the field, we investigate them by incorporating them in a sand wave model and, from that, deduce their specific effects. We use an non-linear idealized process-based model (Sand Wave Code, SWC), which is designed specifically to describe sand wave dynamics. Starting from small disturbances of the seabed and some basic local conditions (e.g. flow velocity and mean water depth), we simulate, in this approach, sand waves from their initial state up to their finite amplitude. The model is based on stability analysis, and an idealized model by Németh et al. (2006), further developed by Van den Berg and Van Damme (2006). So far it is the only non-linear sand wave model available and it allows simulations of all stages of sand wave evolution.

In the few studies using this non-linear model, only the basic processes have been taken into account, such as bed load sediment transport and a symmetric tidal flow. Comparisons with observed single sand wave transects have been made to test the accuracy of model results (Van den Berg and Van Damme, 2006; Németh et al., 2007). However, detailed comparison of model results with observed sand waves, has not yet been accomplished.

In this thesis, we validate the existing SWC and include relevant physical processes, such as surface waves and suspended sediment, to relate them to variations and extremes in sand waves characteristics. Our specific interest is 
firstly to understand which environmental factors cause the sand wave shape and variation and, secondly, to predict the variation in characteristics spatially (e.g. between different sand wave areas) and temporary (e.g. due to seasonal variability).

First, a detailed comparison between the Golden Gate sand wave field and the SWC is carried out. The results of the SWC compare reasonably well with the observed sand waves when both an oscillating and a residual current are taken into account. Except for one transect, where the water depth was relatively shallow, it seems enough to implement this forcing and bed load sediment transport to find the sand wave height, length and shape close to the observed values for the different locations. Current velocity together with water depth, seem to be the most important factors influencing sand wave characteristics. Simulations with longer domains give an indication of the possible variation within a single transect.

Second, suspended sediment is implemented in the SWC, and its effect is investigated under calm weather conditions. The results show that suspended sediment in general (1) shortens and lowers the sand waves, (2) increases the growth and migration rate, and (3) decreases the crest/trough ratio for the sand wave length and height. The qualitative effect of suspended sediment is robust under variation of the water depth and the grain size. Smaller grain sizes, stronger currents, or more asymmetric currents, increase the quantitative suspended sediment effects. Although the suspended sediment transport is small compared to the bed load transport, it can significantly affect the long term sand wave evolution and final shape. The predicted suspended sediment concentrations are reasonable when compared with observations under sand wave conditions.

Furthermore, the results of the SWC show that surface waves can significantly influence the sand wave shape and migration. In general, surface waves lower the sand wave height and cause migration in the direction of the surface wave propagation. The shape of the sand wave changes to a broader crest, milder slopes and a smaller trough. The quantitative effect depends both on the surface wave characteristics and the sand wave environment. Though larger surface waves lower the sand waves more, due to their low frequency of occurrence the effect on sand waves is smaller than that of smaller, but more frequently occurring, surface waves. The effect of surface waves increases for decreasing tidal currents and decreasing water depths. The effect of surface waves is not linear with the surface wave height. Including surface waves improves the sand wave model predictions of sand wave height and migration rate. Results of simulations for two areas in the North Sea are in range with observed sand wave values.

Finally, observations from the North Sea indicate a trend of coarser sediment with a higher degree of sorting at sand wave crests. We extended the SWC to account for the presence and transport of non-uniform sediment. The extension involves an active layer as well as a fractional calculation of sediment transport, which includes hiding-exposure effects. Simulations of a growing sand wave for a bimodal mixture indicate a coarsening trend towards the crest. In the 
sand wave troughs the sediment remains mixed during the sand wave evolution and becomes finer when the sand wave growth decreases. The heterogeneous sediment has no significant effect on the sand wave height and length. The model results show qualitative agreement with observations from various sites in the North Sea. 


\section{Samenvatting}

De zeebodem van ondiepe zeeën is zelden vlak en vaak dynamisch. De complexe interactie tussen golven, getij en sediment zorgt ervoor dat de bodem constant verandert en dat verschillende bodemvormen voorkomen. Een veel voorkomende bodemvorm is de zandgolf. Deze is bijvoorbeeld waargenomen in de Noordzee (Van der Veen et al., 2006), de Bisanseto Zee (nabij Japan, Knaapen and Hulscher, 2002) en nabij San Francisco Bay (Verenigde Staten, Barnard et al., 2006). Zandgolven ontstaan in zeeën waar het getij sterk is en de waterdiepte tussen de 10 en de 55 meter ligt (Bijker et al., 1998). Ook moet er op de bodem voldoende zand aanwezig zijn.

Zandgolven zijn min of meer regelmatige patronen in de zeebodem met toppen die tot een derde van de waterdiepte kunnen groeien, hun golflengte bestrijkt enkele honderden meters (McCave, 1971). Zandgolven kunnen daarnaast migreren met een snelheid variërend van enkele meters tot enkele tientallen meters per jaar.

Door hun migratie en hun ruimtelijke dimensies kunnen zandgolven menselijke activiteiten, zoals scheepvaartroutes, pijpleidingen, kabels en windmolen parken beïvloeden. Met betrekking tot deze offshore activiteiten zijn niet alleen de gemiddelde karakteristieken van zandgolven van belang, maar juist ook de variatie hierin en de extremen, zowel in tijd als in ruimte. Deze variatie kan veroorzaakt worden door omgevingsfactoren zoals de getijstroming, sedimenteigenschappen, oppervlaktegolven, stormseizoenen en waterdiepte.

Omdat de effecten van bovengenoemde omgevingsfactoren moeilijk te scheiden zijn in het veld, gebruiken we een zandgolf model om hun effecten te bestuderen. We gebruiken hiervoor een niet-lineair, geïdealiseerd proces-gebaseerd model (Sand Wave Code, SWC). Dit model is speciaal ontworpen om zandgolfdynamica te beschrijven. De SWC simuleert zandgolven vanaf hun ontstaan tot hun uiteindelijke evenwichtssituatie, beginnend met een kleine verstoring in de zeebodem en een aantal basisgegevens (zoals de snelheid van de getijstroming en de gemiddelde waterdiepte). Het model is gebaseerd op het principe van stabiliteitsanalyse en een geïdealiseerd model van Németh et al. (2006). Het is verder ontwikkeld door Van den Berg and Van Damme (2006). Tot nu toe is dit het enige model dat in staat is om het hele niet-lineaire proces van de evolutie van zandgolven te beschrijven.

In eerdere studies met dit niet-lineaire model zijn meestal alleen de basisprocessen meegenomen, zoals bodemtransport en een symmetrisch getij. De resultaten zijn vergeleken met enkele gemeten transecten om de betrouwbaarheid te bepalen (Van den Berg and Van Damme, 2006; Németh et al., 2007). Een gede- 
tailleerde vergelijking tussen de modelresultaten en geobserveerde zandgolven is echter nog nooit uitgevoerd.

In dit proefschrift valideren we het bestaande zandgolfmodel en voegen we enkele relevante fysische processen, zoals oppervlaktegolven en transport van zwevend sediment toe aan het model. We relateren deze processen aan de variatie en extremen in zandgolfkarakteristieken. Ons doel is ten eerste om te begrijpen welke omgevingsfactoren de vorm van de zandgolf, en de variatie hierin, bepalen. Ten tweede willen we de variatie in zandgolfkarakteristieken zowel in de ruimte (tussen verschillende gebieden) als in de tijd (bijvoorbeeld seizoensvariatie) voorspellen.

Om te beginnen is er een gedetailleerde vergelijking gemaakt tussen de model resultaten en de zandgolven die nabij San Francisco voorkomen. Voor dit gebied komen resultaten van de SWC goed overeen met de geobserveerde zandgolven, mits er zowel een oscillerende als een unidirectionele stromingscomponent wordt meegenomen in het model. Op één transect na, waar de waterdiepte relatief ondiep is, lijkt het voldoende om enkel deze getijdeforcering en het bodemtransport mee te nemen. Hiermee kunnen de zandgolflengte, hoogte en vorm realistisch beschreven worden. Stroming en waterdiepte lijken de belangrijkste factoren te zijn die de zandgolf karakteristieken bepalen. Berekeningen met een langer domein geven verder een indicatie van de mogelijke variatie binnen een transect.

Vervolgens is het transport van zwevend sediment toegevoegd aan de SWC en het effect hiervan is bestudeerd voor rustig weer condities (dat wil zeggen, zonder oppervlaktegolven). Deze toevoeging laat zien dat zwevend sediment in het algemeen (1) de zandgolven korter en lager maakt, (2) de groei en de migratie vergroot, en (3) de top/trog ratio voor de hoogte en lengte van de zandgolf verkleint. Het kwalitatieve effect van zwevend sediment is niet afhankelijk van de waterdiepte of de korrelgrootte. In kwantitatieve zin neemt het effect van zwevend sediment echter toe bij een kleinere korrelgrootte en sterkere of asymmetrische stroming. Hoewel het transport van zwevend sediment een beperkte component van het totale sediment transport is, blijkt het dus een significant effect op de lange termijn evolutie van zandgolven en hun uiteindelijke evenwichtsvorm te hebben. De concentraties zwevend sediment, voorspeld door het model, komen redelijk goed overeen met geobserveerde waarden onder zandgolfcondities.

Resultaten van de SWC laten verder zien dat oppervlaktegolven de vorm en migratie van zandgolven significant kunnen beïnvloeden. In het algemeen verlagen oppervlaktegolven de zandgolf en veroorzaken ze migratie in de richting van de oppervlaktegolven. De zandgolf krijgt een bredere top, flauwere hellingen en een smallere trog. Het kwantitatieve effect hangt zowel af van de karakteristieken van de oppervlaktegolven als van de omgeving van de zandgolf. Het effect van oppervlakte golven is niet lineair met hun hoogte. Ook al verlagen grotere oppervlakte golven de zandgolven verder, het effect van kleinere oppervlakte golven is groter doordat deze vaker voorkomen. Het effect van oppervlakte golven wordt groter bij lagere getij snelheden en bij ondieper water. Het toevoegen van de oppervlaktegolven aan het zandgolfmodel verbetert de 
modelvoorspellingen voor de hoogte en migratie van de zandgolven. Resultaten van simulaties voor twee gebieden in de Noordzee, vallen binnen de range van geobserveerde waarden.

Tot slot laten observaties in de Noordzee een trend zien van grover wordend en beter gesorteerd sediment op de toppen van zandgolven. Daarom hebben we de SWC uitgebreid zodat het ook met niet-uniform sediment kan rekenen. Deze uitbreiding bevat een actieve laag voor het bodemtransport en het sedimenttransport wordt per sedimentfractie uitgerekend om zo rekening te houden met verschillende sediment parameters en het hiding-exposure effect. Simulaties met een bimodaal mengsel van sediment voorspellen dat het sediment op de toppen van de zandgolven grover wordt. In de troggen wordt voorspeld dat het sediment gemengd blijt tijdens de evolutie van de zandgolf. Als de groei van de zandgolven afneemt, wordt het sediment in de trog fijner. Het heterogene sediment heeft geen significant effect op de voorspelde hoogte of lengte van de zandgolven. Deze modelresultaten komen kwalitatief overeen met de observaties in verschillende gebieden in de Noordzee. 


\section{Chapter 1}

\section{Introduction}

\subsection{Sand Waves}

Shelf seas are up to tens of meters deep and often bounded on at least one side by land. The sea floor of these shallow seas is rarely flat and often dynamic. Due to the complex interaction between waves, tide and sediment, the bed changes continuously and various bedforms exist.

Sand banks are the largest of these bedforms, with wave lengths in the order of kilometres and wave heights up to the water depth. They hardly migrate and change slowly, but still interact with human activities such as sand mining (see e.g. Roos, 2004).

Smaller scale bedforms such as (mega)ripples also widely occur in shelf seas. They have wavelengths up to tens of metres and heights in the order of centimetres to decimetres. Their existence and changes are mostly coupled to the changes in weather conditions, leading to both fast migration and fast growth/decay of the bedforms (see e.g. Passchier and Kleinhans, 2005).

In between these scales a widely occurring bedform type is the sand wave, for example observed in the North Sea (Van der Veen et al., 2006), the Bisanseto Sea (Knaapen and Hulscher, 2002) and San Francisco Bay (Barnard et al., 2006). Figure 1.1 shows the occurrence of both sand waves and sand banks in the North Sea. Sand waves occur where tidal currents are strong, the water depth is 10 to $55 \mathrm{~m}$ (Bijker et al., 1998) and sand is in good supply. Sand waves form more or less regular wavelike patterns on the seabed with crests up to one third of the water depth and wave lengths of hundreds of metres (McCave, 1971). Migration of sand waves can be in the order of metres up to tens of metres per year. Sand waves can occur together with other bedforms (Knaapen et al., 2001). They can coexist with sand banks and shoreface-connected ridges, covering mainly the flanks of these larger bedforms (Idier et al., 2002). On top of the sand waves (mega)ripples appear, migrating and changing faster than the sand waves themselves (Passchier and Kleinhans, 2005).

When describing sand waves, different characteristics can be used. In describing sand waves as a wavelike pattern, the wavelength and amplitude are the main characteristics (figure 4.2a). However, sand waves often show crest-trough asymmetry: a sharper higher crest and a shallower longer trough (figure $4.2 \mathrm{~b}$ ). This results in a difference between the crest and trough for both the amplitude and the wave length. Also lee-stoss asymmetry can occur, for example due to 


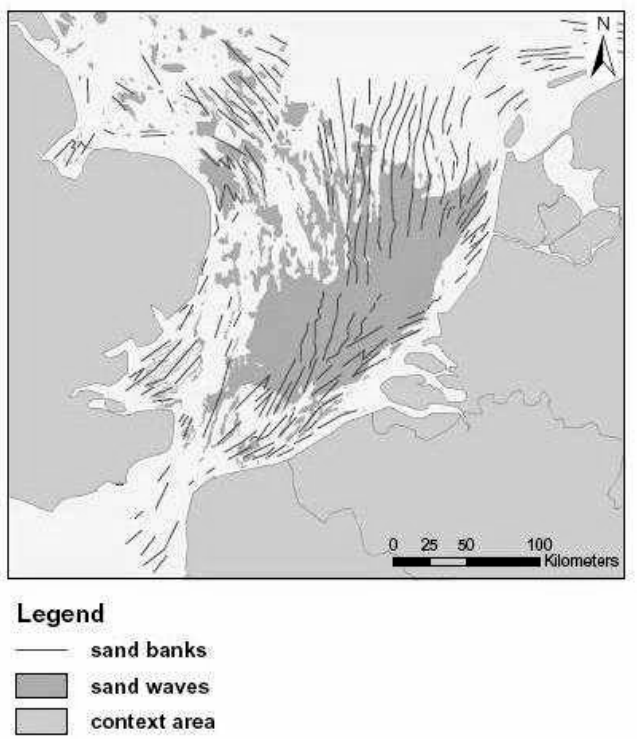

Figure 1.1: Sand wave and sand bank occurrence in the Southern part of the North Sea. Left the UK, right Holland.

an asymmetric tidal current (figure 4.2c), and in time sand waves can grow as well as migrate (figure $4.2 \mathrm{~d}$ ). These various asymmetries combined with the dynamic sand wave behaviour often result in sand wave fields with highly variable sand wave characteristics, both in space and time. Figure 1.3 shows an example of two different sand wave patches in the North Sea.

\subsection{Human Interaction}

Because of their migration speed and spatial dimensions, sand waves can interfere with anthropogenic activities. For example, sand wave occurrence in the region of shipping lanes is one of the reasons why regularly monitoring of these channels is required, as it is important to maintain a certain navigation depth for shipping (Dorst et al., 2007). To avoid that the nautical depth becomes shallower than the critical value required for shipping, dredging takes place.

Secondly, many pipelines and cables are buried in the seabed for the transportation of fossil fuels, electricity and digital information. For protection, pipelines are buried in the sea bed, though excessive burial should be prevented, since this burial of pipelines is expensive. However if they are not buried deep enough, they can be exposed by a migrating sand wave (Morelissen et al., 2003).

Thirdly, migrating sand waves might affect the stability of (planned) wind parks, as they change the water depth around the poles. Besides, these parks might trigger formation of large scale bed forms (Van der Veen et al., 2007).

More generally, sand waves migration can give information on the overall 

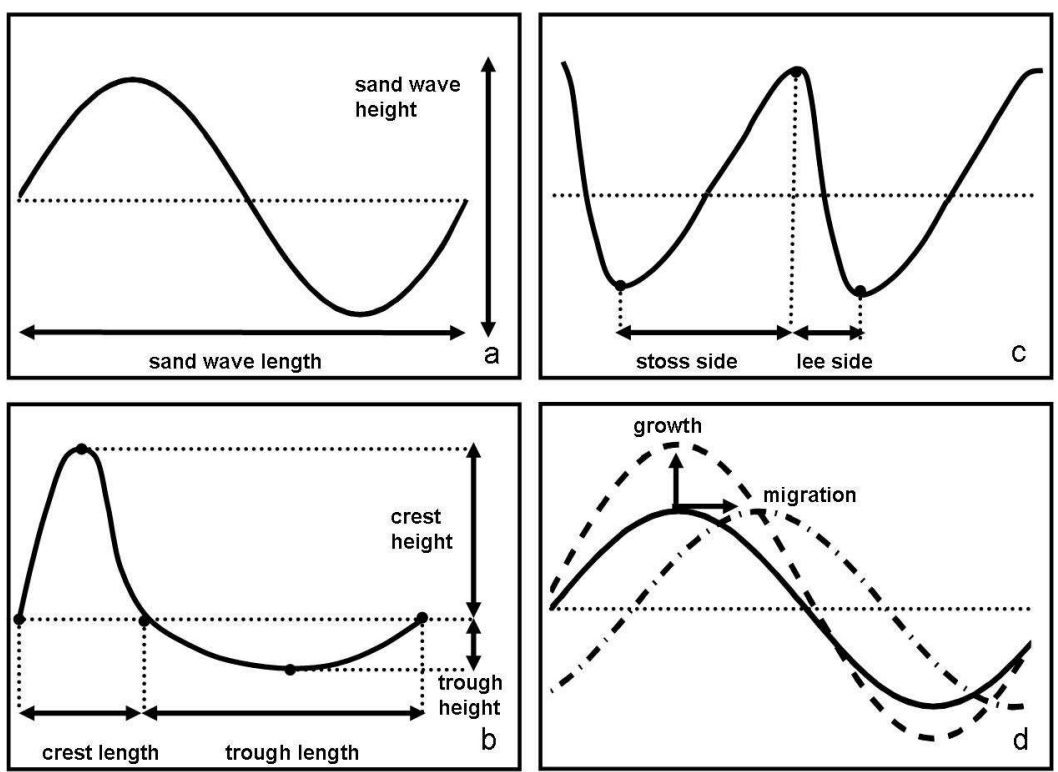

Figure 1.2: Sand wave characteristics, a: idealized sinusoidal sand wave, b: cresttrough assymmetry: sharp crest shallow trough, c: lee-stoss assymmetry: steeper lee side d: growth and migration
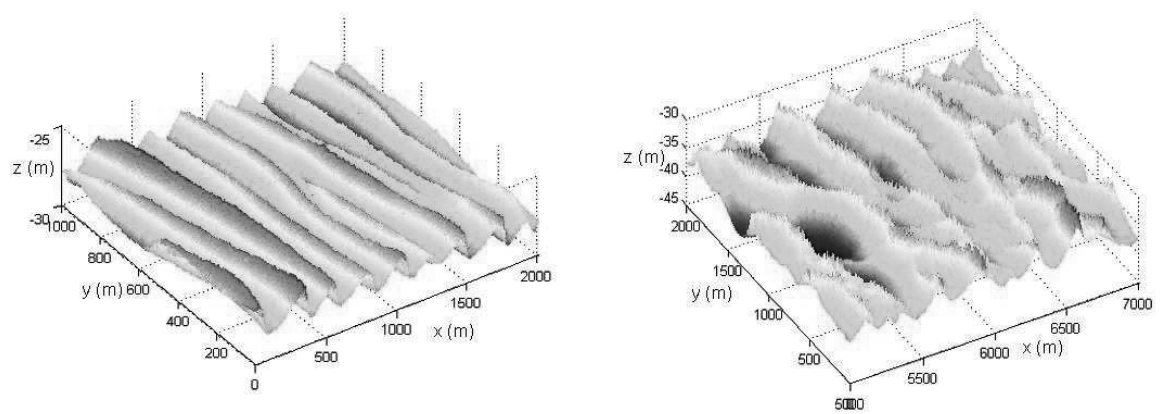

Figure 1.3: Two patches of sand waves on different locations in the North Sea. Note that the length scales are different for the two patches. Data courtesy of North Sea Directorate, The Netherlands. 
sediment transport in shallow seas. Indirectly sand waves can affect the sediment transport by changing the flow. This can lead to erosion or deposition in (coastal) areas (Barnard et al., 2006).

In relation to offshore activities, not only the mean characteristics of sand waves are important but especially the variation and extremes, in both space and time. Variation can be caused by variation in environmental factors, such as in tidal flow, sediment characteristics, wind waves, storm seasons and water depth. Variation occurs both in space, e.g. in different areas sand waves have different characteristics, and in time, e.g. sand waves migrate and grow or decay at a certain place. In this thesis, our specific interest is firstly to understand which environmental factors cause the sand wave shape and variation and, secondly, to predict the variation in characteristics between different sand wave areas and in time (e.g. due to seasonal variability). As these environmental factors are difficult to separate in the field, we investigate this by incorporating them in a sand wave model and, from that, deduce their specific effects.

\subsection{Sand Wave Observations}

Basically two main research approaches are used when investigating sand waves; observing the seabed and modelling the seabed. Sand waves were already observed early in the 20th century (Veen, 1935). For example, McCave (1971) investigates sand waves in the North Sea and associates their characteristics with physical processes in their vicinity, such as wave activity, suspended sediment transport, water depth and grain size. Smith (1988) studies a specific sand wave area in the southern North Sea were sand waves are strikingly asymmetric and limited by the limited sediment supply. Harris (1989) describes a sand wave field in Adolphus Channel (Australia), where sand wave asymmetry changes due to a combination of wind and currents in the monsoon season. More recently, observing techniques became more accurate and observations more detailed. Barnard et al. (2006) shows detailed observation of a sand wave field near the Golden Gate Channel, and Buijsman and Ridderinkhof (2008a,b) investigate detailed sand wave data from the Marsdiep (the Netherlands). Both regions contain highly variable sand waves and relatively high flow velocities. Other detailed studies were published by e.g. Passchier and Kleinhans (2005) and Van Dijk and Kleinhans (2005). The former focusses on the influence of weather conditions leading to different shaped sand waves. The latter describes in detail two sand wave areas in the North Sea and their hydrodynamic and sedimentological circumstances. From that, they discuss the influences of various processes on the sand wave morphology and dynamic behaviour.

In general, observations provide direct information on the actual bed form shapes on the measured location and, when surveyed more than once, also about the changes over time. Information on sediment transport and expected sand wave behaviour can then be extracted. It is only since a few decades that measuring the sea floor with an appropriate precision has been possible. In order to detect sand wave migration, not only the vertical position of the sea floor should be measured accurately, but also its exact spatial (horizontal) location. 
Though accurate measuring is possible (Dorst et al. (2009)), surveys are often very expensive and little detailed data is available.

\subsection{Sand Wave Modelling}

Sand wave modelling provides more generic knowledge than observations. Results are extrapolated more easily to other locations and circumstances, and the effect of environmental factors can be studied separately. Modelling sand wave characteristics also improves our knowledge of sand wave behaviour and the processes underlying this behaviour. In this way modelling helps where data is unavailable or insufficient.

Within the sand wave modelling approach, one can start from different perspectives. Starting from observations several methods are designed to gain more generic knowledge. Dorst et al. (2009) formulates a statistical method that provides insight in the morphodynamics of the sea floor, from observed bathymetries, to improve resurvey policies. Knaapen (2005) developed a sand wave migration predictor based on measured sand wave characteristics, and in Knaapen and Hulscher (2002) a model is tuned with data from the Bisanseto Sea to describe the sand wave growth after dredging in that area. Van der Veen et al. (2006) combined a linear sand wave and sand bank model with field data in a GIS environment to predict where sand waves and sand banks can occur in the North Sea.

Process based models can be used to investigate in more detail which processes contribute to the different stages of sand wave growth and shape changes. Process based modelling aims at describing the important physical processes in terms of differential equations.

Complex or 'full' process based models can include many different processes (e.g. tidal current, wind- and wave-driven currents, density gradients, sediment transport) describing them within broad classes of problems over different temporal and spatial scales. It aims at including these processes as realistic as possible and is able to deal with complex, site specific, geometries (e.g. the observed bathymetry). For example Tonnon et al. (2007) used a complex model to investigate which processes affected an existing sand lump with sand wave dimensions over a time span of 15 years.

At this moment no full process based model has achieved to describe the formation and long term evolution of sand waves. This is mostly due to the required computational time and the problems with boundary conditions. The formation of residual circulation cells over sand waves makes that both the space and the tidal time calculations require a high accuracy, also to keep numerical diffusion to a minimum. Since these circulation cells occur in the vertical, the flow can not be modelled in a depth averaged way. Due to their usability in broad classes of problems, full process based models often do not meet these requirements (Section 6.1.3).

Because of the strict requirements for modelling sand wave formation and growth, and the interest in the physical mechanisms behind this, idealized models are formulated to gain knowledge. In contrast to full process based models, 
idealized process based models assume a simple geometry, input and boundary conditions, to study morphological features at a morphodynamic time scale, in this case decades to centuries. Idealized process based models aim at retaining the essential physics, while keeping the model as simple as possible (an overview of sand waves modelling with this approach is given in Besio et al. (2008)). Based on Huthnance (1982), Hulscher (1996) introduced a three dimensional linear idealized process based model to describe sand bank and sand wave formation. As the model is linearized in the bed amplitude, it only gives information on the initial stage of sand wave formation, i.e. when sand waves are so small that non-linear interaction between the bedforms and the flow are negligible. Gerkema (2000) and Komarova and Hulscher (2000) further improved this model. Besio et al. (2003b) continued in the linear regime, extending the linear stability analysis and showing the need for a minimum amplitude of the tidal current and for sandy grain sizes for sand waves to form. The effect of a residual current was further investigated by Németh et al. (2002). Besio et al. (2004) showed that both migration in the current direction and against it can occur. Blondeaux and Vittori $(2005 \mathrm{a}, \mathrm{b})$ extended this model by including processes like wind waves, suspended sediment and a simple algebraic eddy viscosity (instead of a constant eddy viscosity). In their latter article they test the model in offshore cases with trenches and sand pits which in some cases trigger large scale bedforms. The resulting sand wave length and orientation compare reasonably well with two observed sand wave fields, but the investigation of physical processes is kept to a minimum. Van Oyen and Blondeaux (2009) used the linear model in the sand wave regime to investigate the grain size sorting over sand waves. Borsje et al. (2009) implemented the effect of biology in the linear model.

The major drawback of these linear models is that they only describe the initial sand wave behaviour. This excludes information on the final shape of sand waves, e.g. their height and asymmetry, as well as the processes sustaining the equilibrium profiles. In this thesis we use an non-linear idealized process based model (Sand Wave Code, SWC). This model is designed specifically to describe sand wave dynamics. In this approach we simulate sand waves from their initial state up to their finite amplitude, starting from small disturbances of the seabed and some basic local conditions (e.g. flow velocity and mean water depth). The model is based on stability analysis, and an idealized model by Németh et al. (2006), further developed by Van den Berg and Van Damme (2006). So far it is the only non-linear sand wave model available and it allows simulations of all stages of sand wave evolution.

In the few studies using this non-linear model, only the basic processes are taken into account, such as bed load sediment transport and a symmetric tidal flow. Comparisons with observed single transects are made to test the accuracy of model results (Van den Berg and Van Damme, 2006; Németh et al., 2007). The model has shown good results when compared with field data. However, detailed comparison of model results with observed sand waves, including fully grown sand wave characteristics, has not yet been accomplished. Model parametres, such as viscosity and slope effects are tested for their influence on predic- 
tions. Also the importance of tidal constituents over the whole process of sand wave growth and saturation is studied (Németh et al., 2002, 2006, 2007). The influence of other environmental processes has not been studied in detail. For example, as pointed out by Van Dijk and Kleinhans (2005), the effect of surface waves and suspended sediment remains to be explained and can be significant.

Differences in sand wave height, length and migration speed occur between locations and in time. These variations are not yet understood, nor is it, from a theoretical basis, possible to give ranges of possible variations on different locations (Hulscher and Van den Brink, 2001). Still, these variations and the extreme characteristics are most important for interaction with human activities. Though part of the occurring variation might be of stochastic origin (i.e. due to chaos or chance), the variation also occurs due to the physical processes that vary both in time and space. For example sediment characteristics can influence the sand wave behaviour, areas can experience often occurring large storms and accompanying surface waves. The effect of physical processes is twofold. Firstly simply their occurrence and magnitude (e.g. surface waves, grain size) leads to variation in sand wave characteristics between areas where the physical processes are different. Secondly, the variation in these physical processes (e.g. storm events, variation in grain sizes over an area) again leads to variation in sand wave behaviour and shape both in space and time.

In this thesis, we try to include relevant physical processes, such as surface waves and suspended sediment, in the idealized process based model (Van den Berg and Van Damme, 2006) and to relate them to variations and extremes in sand waves characteristics. The overall research goal is to describe and understand variations in sand wave characteristics, starting from the physical processes that take place in the vicinity of sand waves. Including these processes in our numerical model will enable us to better predict sand wave characteristics, both in space and time.

\subsection{Research Questions}

From the literature overview above we distinguish two main points in which sand wave modelling can be improved. First, detailed comparisons with observed sand waves (in the non-linear regime) are scarce leading to sand wave models that are poorly validated. Second, there is a lack of knowledge with regard to the influence of various physical processes on the characteristics of full grown sand wave and their variation (temporal and spatial).

The aim of this research project is to fill in these gaps. The main research questions are formulated as follows:

1. To what extent do the Sand Wave Code results describe and explain observed (variation in) sand wave fields.

2. Do the following physical processes significantly contribute to the modelled sand wave characteristics and their variation, and if so, in what way and to what extent: 
- suspended sediment transport (vs. bed load transport)

- wind waves (vs. tidal flow)

- variation in and sorting of different grain sizes

\subsection{Thesis Outline}

This thesis is organised as follows:

Chapter 2 describes a case study carried out for a sand wave field at the mouth of the San Francisco Bay. Here, large variations in both sand wave characteristics and their surroundings, are observed which make it possible to validate the SWC over a large range of values.

Chapter 3 shows the effect of surface waves on the sand wave characteristics. The surface waves are included using the linear wave theory. Different wave types and regimes are tested. The surface wave effects are investigated under different environmental conditions (water depth and tidal velocity). The model results are compared with field observations and the possible physical processes underlying the surface wave effects are investigated.

Chapter 4 continues with the effect of the implementation of suspended sediment in the SWC. The advection diffusion equation is implemented in the model to describe the sediment distribution over the water column, which is then transported by the current.

Chapter 5 presents the work done on grain size sorting over sand waves. The extended model accounts for the presence and transport of non-uniform sediment. The extension involves an active layer as well as a fractional calculation of sediment transport, which includes hiding-exposure effects. Filed data shows a tendency of increasing grain size towards the crests of sand waves. Simulations of a growing sand wave for a homogeneous sediment and a bimodal mixture are carried out to investigate the sorting process and its possible effect on sand wave evolution.

Chapter 6 consists of a discussion on general topics e.g. related to the used model and the investigated processes.

Chapter 7 finally presents the main conclusions and recommendations for further research on sand wave variation, referring to the main research questions as stated in section 1.5. 


\title{
Chapter 2
}

\section{Simulating and understanding sand wave variation, a case study of the Golden Gate sand waves ${ }^{1}$}

\begin{abstract}
In this chapter we present a detailed comparison between the Golden Gate sand wave field and the results of the non-linear sand wave model. As the Golden Gate sand waves show large variation in their characteristics and in their environmental physics, this area gives us the opportunity to study sand wave variation between locations, within one well measured, large area. The nonlinear model used in this chapter is presently the only tool that gives information on the non-linear large amplitude sand wave evolution. The model is used to increase our understanding in the coupling between the environmental variation and the sand wave characteristics. Results of the model show that it is able to describe the variation in the Golden Gate sand waves well when both the local oscillating tidal current and the residual current are taken into account. Current and water depth seem to be the most important factors influencing sand wave characteristics. The simulation results give further confidence in the underlying model hypothesis and assumptions.
\end{abstract}

\section{$2.1 \quad$ Introduction}

Several patches of rhythmic bedforms are clearly visible on the sea bed near the Golden Gate entrance of San Francisco Bay (Figure 2.1). Bedforms are typical features in shallow seas, though their shape and morphology are highly variable. We classify the bedforms as sand waves in accordance with their geometrical scale and migration rate. In this area, sand wave lengths are around $100 \mathrm{~m}$, sand wave heights are typically about $5 \mathrm{~m}$, and they migrate several meters per year. Due to their scale and migration, sand waves are expected to influence the tidal currents and play an important role in the sediment dynamics in the region. Understanding the sediment flux in the vicinity of the Golden Gate inlet is integral to the proper management of sediment in the entire Bay region. The Golden Gate sand wave field has been measured with high resolution over

\footnotetext{
${ }^{1}$ This chapter has been published as: Sterlini, F., S. J. M. H. Hulscher, and D. M. Hanes (2009), Simulating and understanding sand wave variation: A case study of the Golden Gate sand waves, J. Geophys. Res., 114, F02007, doi:10.1029/2008JF000999.
} 
the past few years. The measurements show dynamic sand waves with large variation in shape and orientation. The water depth $(15 \mathrm{~m}-70 \mathrm{~m})$ and flow velocity $(0.3 \mathrm{~m} / \mathrm{s}-1.5 \mathrm{~m} / \mathrm{s})$ also exhibit large spatial variations. However, it is yet unclear which environmental factors contribute most to the observed sand wave variations.

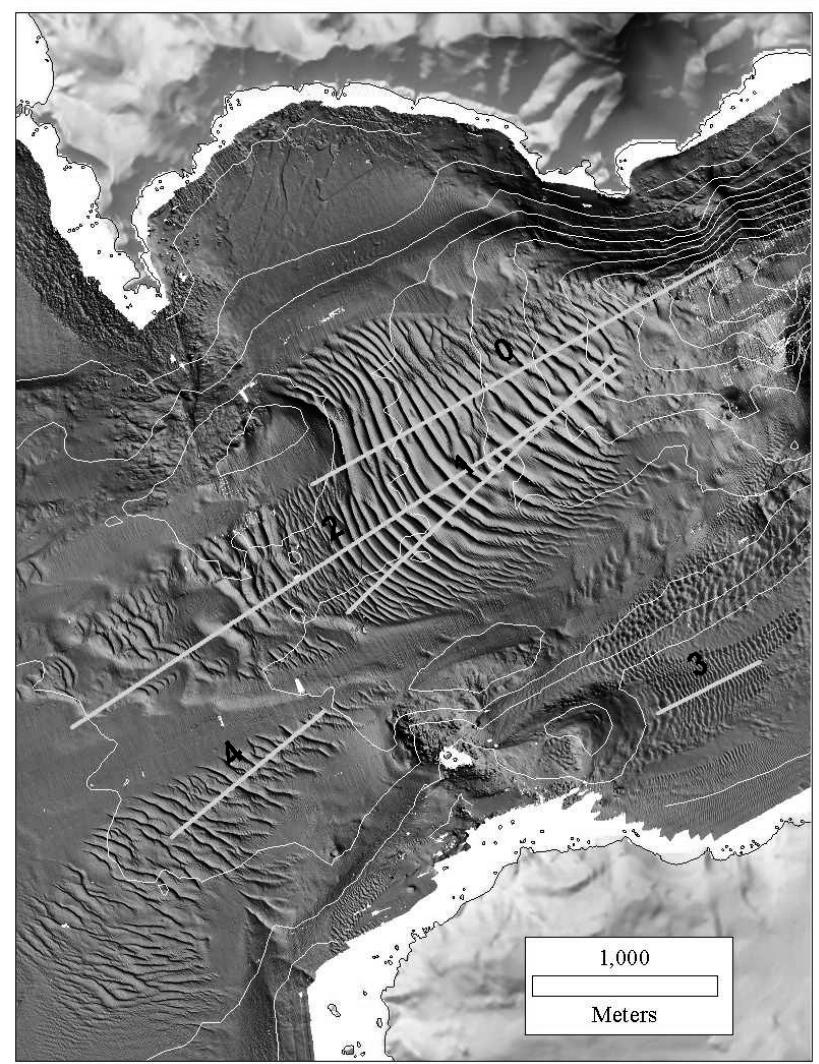

Figure 2.1: San Francisco Bay area with the described sand wave transects.

Numerical models based on stability analyses have been used to understand the formation and evolution of sand waves (Hulscher and Van den Brink, 2001; Besio et al., 2003a, 2004; Van der Veen et al., 2006). Most modelling research is carried out in the linear regime, i.e. both the interaction between the flow and the sea bed, and the sand wave growth is assumed to be linear. This only holds for the initial stage of sand wave growth. Linear modeling therefore excludes information on the final shape of the sand waves as there the non-linear interaction becomes important, leading to a decrease in sand wave growth, a change of the sand wave form and in the end a final sand wave shape that is in equilibrium with the flow. In the few non-linear model studies, the influence of environmental processes has not been studied in detail (Németh et al., 2006; 
Van den Berg and Van Damme, 2006; Németh et al., 2007). Model results are sometimes compared with data from single transects to test the accuracy of model results and the underlying physical hypothesis (Van den Berg and Van Damme, 2006; Németh et al., 2007). A comparison between observations and the model results to test in detail the models ability to describe all sand wave characteristics and its ability to deal with variations between locations has not yet been accomplished.

We are interested in the physical causes of variation in sand wave characteristics between different locations. We aim to better understand the physical background of the morphological features. Our main question in this chapter is: "Can we explain sand wave variation between locations with differing physical environmental processes using a simplified non-linear model?". To answer this question we compare the Golden Gate sand waves observations with the results of the non-linear sand wave model. As the Golden Gate sand waves show large variation in their characteristics and in their physical environment, this area gives us the opportunity to study sand wave variation within a single, well measured, large area. The model used in this chapter is presently the only tool that gives information on the non-linear large amplitude sand wave evolution. The model is used to increase our understanding of the coupling between the environmental variation and the sand wave characteristics. Still, the underlying theory (Section 2.3) and the model simplifications have not been tested in detail against data. Therefore, our second aim is to further test the underlying theory. If the model is able to predict the sand wave variation reasonably, the knowledge can be used to predict sand wave characteristics in other locations, perhaps even where no measurements are available.

As the main strength of the non-linear model is the inclusion of the sand wave height and shape, our focus is on the sand wave morphology and less on the dynamics (time evolution and migration). Another reason we do not focus on the dynamics here, is that the migration patterns of the Golden Gate sand waves are complicated and still under investigation (Section 2.2).

We start with describing the San Francisco Bay area and the measured sand wave characteristics in more detail in Section 2.2. The numerical model is described in Section 2.3. The model results are compared with the field data and a sensitivity analysis is carried out for important model parameters (Section 2.4). Discussion and conclusions follow in Sections 2.5 and 2.6.

\subsection{Measurements}

\subsubsection{General}

San Francisco Bay is located on the west coast of the USA and is connected to the Pacific Ocean through the Golden Gate (Fig. 2.1). Maximum tidal currents through the channel typically exceed $2.5 \mathrm{~m} / \mathrm{s}$, and the channel has scoured down to bedrock with a maximum depth of $113 \mathrm{~m}$.

Sand waves exist on both sides of the Golden Gate Channel. The $4 \mathrm{~km}^{2}$ sand wave field outside the Golden Gate Channel (Figure 2.1) has recently been inves- 
Table 2.1: Information about the field characteristics and measurement characteristics, on the transects. \# points are the number of data points over the transects. $U_{o s c}$ is the oscillating part of the current, estimated from both Cheng and Gartner (1984) ( $\left.U_{\text {osc }}{ }^{\prime} 84\right)$ and Delft3D simulations $\left(U_{\text {osc }}\right.$ D3D). Using the Delft3D output, also the unidirectional flow component is estimated $\left(U_{\text {uni }}\right.$ D3D).

\begin{tabular}{lccccccc}
\hline $\begin{array}{l}\text { pro- } \\
\text { file }\end{array}$ & $\begin{array}{c}\text { length } \\
(\mathrm{m})\end{array}$ & $\begin{array}{c}\text { water } \\
\text { depth }(\mathrm{m})\end{array}$ & $\begin{array}{c}\# \\
\text { points }\end{array}$ & $\begin{array}{c}\text { inter- } \\
\text { val }(\mathrm{m})\end{array}$ & $\begin{array}{c}U_{\text {osc }}{ }^{\prime} 84 \\
(\mathrm{~m} / \mathrm{s})\end{array}$ & $\begin{array}{c}U_{\text {osc }} \mathrm{D} 3 \mathrm{D} \\
(\mathrm{m} / \mathrm{s})\end{array}$ & $\begin{array}{c}U_{\text {uni }} \mathrm{D} 3 \mathrm{D} \\
(\mathrm{m} / \mathrm{s})\end{array}$ \\
\hline 1 & 2002 & $40-70$ & $200+1$ & 10 & $0.4-1.2$ & 1.3 & 0.5 \\
2 & 3520 & $30-70$ & $176+1$ & 20 & $0.4-1.2$ & 1.1 & 0.5 \\
3 & 620 & $13-18$ & $124+1$ & 5 & 0.45 & 0.5 & -0.3 \\
4 & 1065 & $32-40$ & $213+1$ & 5 & $0.6-1.2$ & 1.1 & 0.3 \\
\hline
\end{tabular}

tigated by Barnard et al. (2006). The entire sand wave field in the mouth of San Francisco Bay was mapped in 2004, 2005, 2007. The region along the centerline of the sand waves (transect 0 in Figure 2.1) was mapped four times in 2004: on 17, 18, 25, and 30 October; three times in 2005: on 17 and 18 September and 30 October and on 4 February 2007. The repeated surveys focused on 19 distinct contiguous bedforms in water depths between approximately $35 \mathrm{~m}$ and $80 \mathrm{~m}$, shallowing seaward of the Golden Gate approaching the large ebb tidal shoal. Sand wave shapes range from ebb-dominated to symmetric. Wavelengths are between 32 and $145 \mathrm{~m}$, and the mean sand wave height is $4.1 \mathrm{~m}$. Grain size on the bed surface of these sand waves is coarse (typically $0.8 \mathrm{~mm}$ ).

Over the entire area, the sand waves have diverse shapes and sizes. The largest sand wave has a wavelength of $220 \mathrm{~m}$ and a height of $10 \mathrm{~m}$. Net migration varies over time, and was approximately 5-10m/yr in the 2004 to 2005 time frame. Crest positions can oscillate approximately $3 \mathrm{~m} / \mathrm{d}$ depending on the daily tidal current patterns.

Cheng and Gartner (1984) measured flow velocities near the mouth of San Francisco Bay ranging between $0.3 \mathrm{~m} / \mathrm{s}$ and $1.3 \mathrm{~m} / \mathrm{s}$. Recent measurements show that velocities in the Golden Gate channel often exceed the $2.5 \mathrm{~m} / \mathrm{s}$ (Barnard et al., 2006). A hydrodynamic 2D horizontal simulation shows tidal flows of comparable magnitudes (Barnard et al., 2007).

Because of this large range in both the sand wave shape and the physical environment, the Golden Gate sand waves present an excellent opportunity to investigate the relation between the environmental and the sand wave characteristics.

\subsubsection{Transects}

To study sand wave variation, 4 transects (Figure 2.1, transects 1-4) are used for comparison with the numerical results described in Section 2.4. In Table 2.1 some field and measurement characteristics are listed. Table 2.2 shows the sand wave characteristics, defined using the Bedform Tracking Tool (BTT) of Van der Mark et al. (2007). The four transects are chosen such that they represent the range of physical conditions and sand wave characteristics in the entire sand 
Table 2.2: Sand wave characteristics from the Bedform Tracking Tool for the transects. Hsw is the sand wave height, Lsw the sand wave length. Left and right for the slopes refers to the transect figures.

\begin{tabular}{lcccc}
\hline profile & $\begin{array}{c}\text { Hsw }(\mathrm{m}) \\
\min ; \operatorname{mean} ; \max \end{array}$ & $\begin{array}{c}\text { Lsw }(\mathrm{m}) \\
\min ; \operatorname{mean} ; \max \end{array}$ & $\begin{array}{c}\text { Landward side slope } \\
\min ; \text { mean } ; \max \end{array}$ & $\begin{array}{c}\text { Seaward side slope } \\
\text { min } ; \operatorname{mean} ; \max \end{array}$ \\
\hline 0 & $0.9 ; 4.1 ; 6.5$ & $32 ; 85 ; 144$ & $0.03 ; 0.10 ; 0.30$ & $0.05 ; 0.16 ; 0.27$ \\
1 & $2.5 ; 4.7 ; 6.9$ & $70 ; 88 ; 110$ & $0.05 ; 0.14 ; 0.23$ & $0.07 ; 0.14 ; 0.24$ \\
2 & $0.7 ; 3.4 ; 7.5$ & $60 ; 129 ; 300$ & $0.01 ; 0.09 ; 0.18$ & $0.01 ; 0.07 ; 0.19$ \\
3 & $0.1 ; 0.5 ; 0.7$ & $15 ; 24 ; 50$ & $0.02 ; 0.09 ; 0.14$ & $0.01 ; 0.04 ; 0.06$ \\
4 & $1.7 ; 2.4 ; 3.3$ & $65 ; 79 ; 85$ & $0.03 ; 0.05 ; 0.06$ & $0.10 ; 0.14 ; 0.18$ \\
\hline
\end{tabular}

wave field. Transects are taken approximately perpendicular to the sand wave crests.

Transects 1 and 2 run through some of the biggest sand waves in the middle of the field. The transects are $2 \mathrm{~km}$ and $3.5 \mathrm{~km}$ long, respectively, and each transect contains approximately 30 sand waves. For transect 1, the largest sand waves (lengths up to $110 \mathrm{~m}$ ) are found in the deeper, sloping area (Figure 2.2). Sand wave height ranges up to $7 \mathrm{~m}$ in this area and is on average $4.6 \mathrm{~m}$. Transect 2 (Figure 2.2) has two large sand waves in the shallower part, with wave lengths around $300 \mathrm{~m}$. These two seem to stand apart from the other sand waves on the transect where wave lengths are closer to $100 \mathrm{~m}$. The waves are on average $3.4 \mathrm{~m}$ high and, like on transect 1, asymmetric and directed towards the Pacific. Measurements (Cheng and Gartner, 1984) and a hydrodynamic 2DH simulation of the tidal flow (Barnard et al., 2007) show that the flow velocities are high in this part if the sand wave field, with maxima between 1.0 and $1.5 \mathrm{~m} / \mathrm{s}$, and averaged over a tide, directed towards the Pacific. Profile 3 (Figure 2.2) is located at the shallow southern part of the mouth covering around 25 sand waves over $600 \mathrm{~m}$. The flow velocity is lower (maximum around $0.5 \mathrm{~m} / \mathrm{s}$ ), and averaged over the tide, directed towards the Golden Gate. The water depth is relatively shallow and the sand waves are small compared to the first two profiles. Sand wave heights are less than $1 \mathrm{~m}$ and wavelengths are around $25 \mathrm{~m}$. Within the transect the variation is small. Profile 4 is situated just outside the San Francisco Bay mouth. Here the sand waves are slightly smaller than on the first two profiles (mean height $2.3 \mathrm{~m}$ and mean length $80 \mathrm{~m}$ ), and again asymmetric, oriented towards the ocean. Over the transect, sand waves are more regular in the middle and towards both the deeper and the shallower part sand waves become more irregular. The transect covers around 15 sand waves.

Sand wave migration has been estimated for transect 0 , using repeated surveys. Figure 2.3 shows a section of transect 0 measured four times over a four year period. Between October 2004 and October 2005 these sand waves migrated seaward, but between October 2005 and February 2007 they migrated landward, in spite of their seaward directed shape asymmetry measured during each survey! Then between February 2007 and April 2008 they migrated seaward again. The migration of the sand waves is obviously variable in time, and 

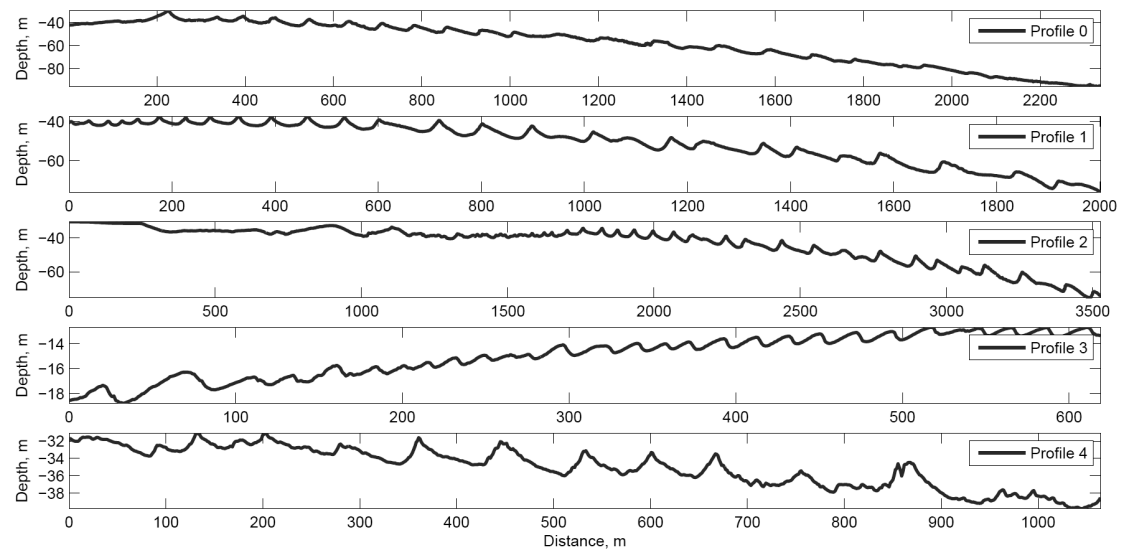

Figure 2.2: Transect 1 (highest panel) to (lowest panel) 4 . With the left side is the seaward side of the transects. Note that the scales vary per transect.

initial investigations of the entire sand wave field indicate that migration varies in space as well. This is currently a topic of active investigation, but at this time the migration of the sand waves is not well understood.

\subsection{Sand Wave Code}

The Sand Wave Code (SWC) used in this study is based on an idealized model by Németh et al. (2006) that was further developed by Van den Berg and Van Damme (2006). It is a two dimensional vertical model, which is developed specifically to describe sand wave evolution from its generation, to its fully grown state. For sand wave fields in the Southern part of the North Sea the SWC has shown good results in describing the wavelength, height and migration (Németh et al., 2002, 2007). However, an in depth comparison with field data has not yet been accomplished.

Results of the idealized model are supposed to represent the trends in the data. The goal is to reproduce the general sand wave patterns; due to nonlinear and stochastic behavior of sediment in turbulent flow, we do not attempt to reproduce the details within sand wave transects.

Accuracy in the presented results are around $15 \%$ for the sand wave height, due to possible fluctuations in the final shape. The accuracy in sand wave length is $20-30 \mathrm{~m}$ as the wave length is tested with length intervals of this spacing. 


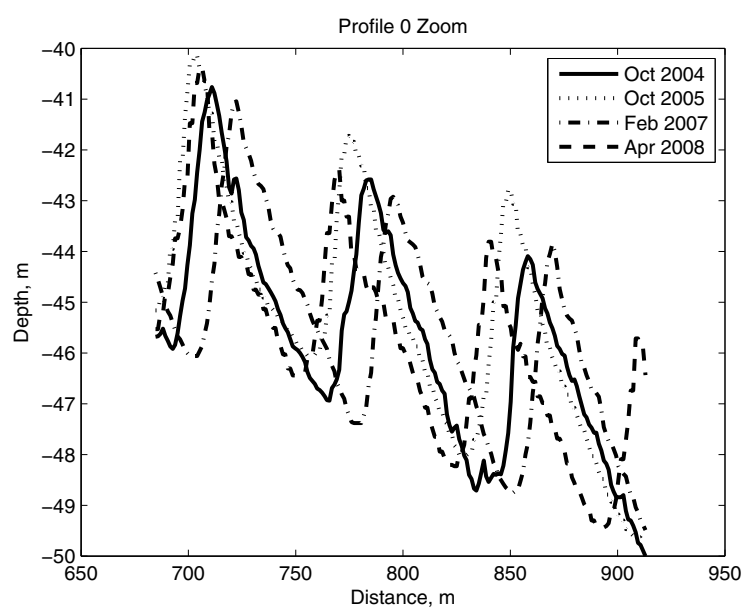

Figure 2.3: Repeated surveys on transect 0 show the sand wave migration in time. Both the migration rate and the migration direction changes in time.

\subsubsection{Sand Wave Theory}

Sand waves are formed due to interaction between a sandy seabed and a tidal flow. Sand waves occur as free instabilities in this system, i.e. there is no direct relation between the scales related to the forcing (tide) and those related to the morphological feature (sand wave) (Dodd et al., 2003). Sand wave occurrence can be understood only if the feedback mechanism between the forcing and the seabed is taken into account. Hulscher (1996) described this mechanism of self organization for sand waves.

Starting from a flat bed with an oscillating current, small perturbations of the sea floor cause small perturbations in the flow field and vice versa. The bed can be either stable, which means that all bed perturbations will be damped, or unstable, which means that certain bed perturbations will grow and the sea bed is changed. This growth is due to flow accelerating when the water depth decreases. This causes a slightly higher flow velocity uphill than downhill (Figure 2.4). Due to the oscillating character of the flow this happens on both sides of the perturbation, causing it to grow instead of to migrate.

If perturbations are unstable the flow field is changed such that, averaged over the tidal cycle, small vertical residual circulation cells occur (Figure 2.5). These cells cause small net sediment transport to the crests of the perturbation, thereby causing growth. Depending on the circumstances such as flow velocity and water depth, perturbations with different lengths will show different growth/decay rates. The fastest growing mode is the perturbation which triggers the fastest initial growth.

For small amplitude perturbations, growth can be described as linear, as the non-linear feedback mechanisms between the flow and the bedform are still negligible. However, as sand waves grow larger, non-linear effects become im- 

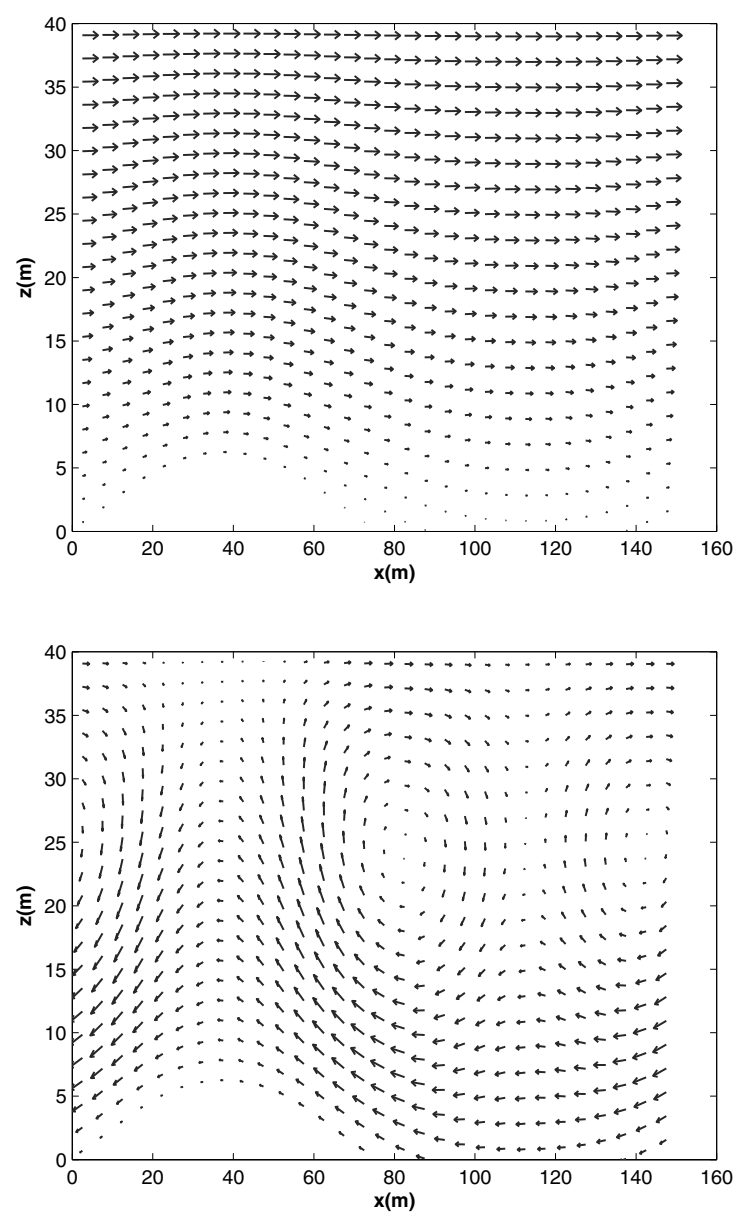

Figure 2.4: Current on two moments during the tidal cycle, over a sand wave. Left the flow during maximum tide (arrows represents flow magnitude multiplied by two), right on flow reversal (arrows represents flow magnitude multiplied by eight).

portant. There are several indicators for the assumption that sand waves are only weakly non-linear: their amplitude is generally smaller than $20 \%$ of the water depth and the predicted fastest growing wave length (growth in height) is close to the observed wave length. Assuming weak non-linearity, the dominating wavelength for linear bedforms will be close to the one dominating in the nonlinear regime, i.e. for full grown sand waves. Subsequently, the fastest growing mode indicates the dominant sand wavelength that is found to be close to the dominating one in reality for weakly non-linear systems (Dodd et al., 2003). 


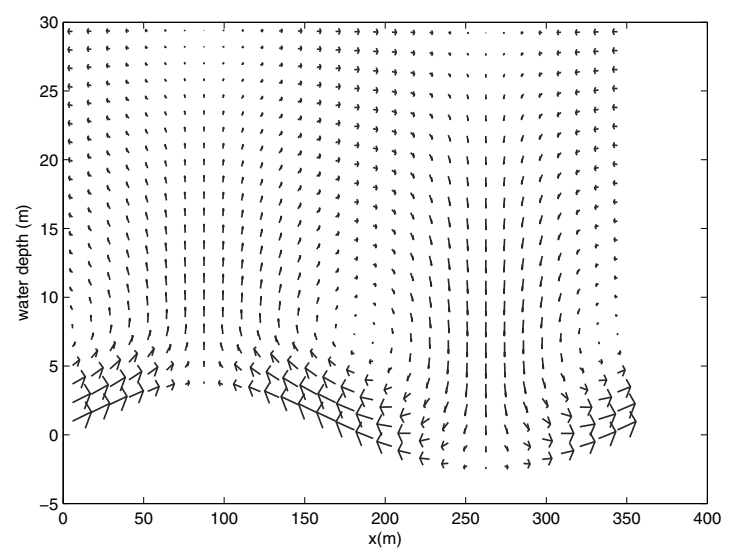

Figure 2.5: Residual circulation, averaged over one tidal cycle. In this unstable case the cells, formed due to interaction between the flow and the bed perturbation, will lead to growth of the perturbation.

\subsubsection{Physical and Numerical Background}

As the model is idealized, a simple geometry, input and boundary conditions are used, to study morphological features at a morphodynamic time scale, i.e decades. Processes are only included when important for the studied object, in this case sand wave evolution.

We start simulations by prescribing sinusoidal, small amplitude, bed waves. Using the bathymetry, a tidal flow is calculated. Since the flow changes over a timescale of hours and the morphology over a timescale of years, the bathymetry is assumed to be invariant within a single tidal cycle $(h(x)$ instead of $h(x, t))$. Once the tidal flow is known, the bed changes are calculated over this typical tide, using a sediment transport equation. This is repeated until the bed evolution exceeds a certain value, after which a new tidal flow is calculated. This, in turn, affects the bed and so the process is iterative. In this way, we are able to simulate the morphological time scale accurately, while avoiding long computation times, as the flow calculations are the most time-consuming part.

The SWC consists of the hydrostatic flow equations for 2DV flow (equations 4.1 and 4.2 ).

$$
\begin{gathered}
\frac{\partial u}{\partial x}+\frac{\partial w}{\partial z}=0 \\
\frac{\partial u}{\partial t}+u \frac{\partial u}{\partial x}+w \frac{\partial w}{\partial z}=-g \frac{\partial \zeta}{\partial x}+A_{v} \frac{\partial^{2} u}{\partial z^{2}}+F(t)
\end{gathered}
$$

In these equations $x$ and $z$ represent the horizontal and vertical directions and $u$ and $w$ the horizontal and vertical flow velocities. The variable $t$ denotes time, $\zeta$ is the water surface elevation, $g$ is the constant of gravity and $A_{v}$ is the constant eddy viscosity. See Figure 2.6 for a sketch of the model geometry. The tidal 


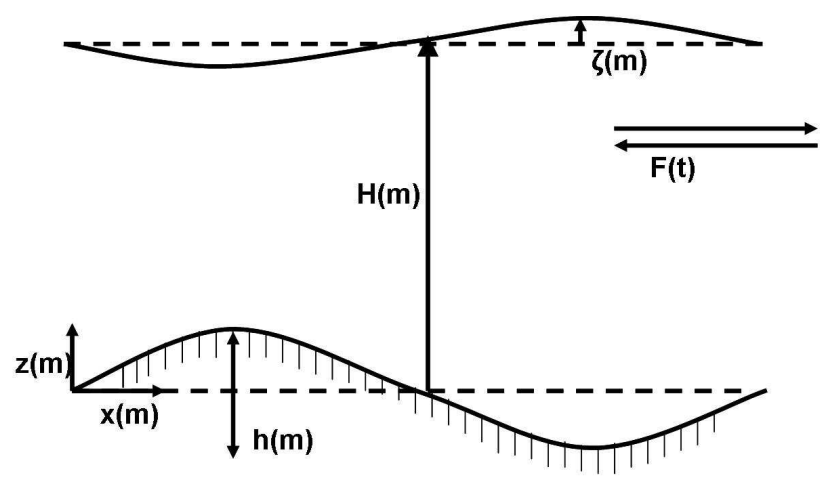

Figure 2.6: Sketch of the domain set up in the model.

flow is prescribed as a sinusoidal current by means of a forcing (equation 4.3). Variation due to spring-neap tide or seasonal changes is not included. This coincides with other studies on sand waves (Van den Berg and Van Damme, 2006; Németh et al., 2002; Besio et al., 2003b).

$$
F(t)=F_{0}+F_{s} \sin (\omega t)+F_{c} \cos (\omega t)
$$

Here $\omega$ is the angular frequency, $1.4 \mathrm{e}^{-4} \mathrm{~s}^{-1}$, and $F_{0}, F_{s}$ and $F_{c}$ are constants depending on the tidal velocity. Boundary conditions at the bed disallow flow perpendicular to the bottom (equation 4.4). Further, a partial slip condition compensates for the constant eddy viscosity, which overestimates the eddy viscosity near the bed (equation 4.5). The parameter $S$ denotes the amount of slip, with $S=0$ indicating perfect slip and $S=\infty$ indicating no slip. At the water surface, there is no friction at and no flow through the surface (equations 4.6 and 4.7$)$.

$$
\begin{gathered}
w-u \frac{\partial h}{\partial x}=\left.0\right|_{\text {seabed }} \\
A_{v} \frac{\partial u}{\partial z}=\left.S u\right|_{\text {seabed }} \\
\frac{\partial u}{\partial z}=\left.0\right|_{\text {surface }} \\
w=\frac{\partial \zeta}{\partial t}+\left.u \frac{\partial \zeta}{\partial x}\right|_{\text {surface }}
\end{gathered}
$$

The flow and the sea bed are coupled through the continuity of sediment (equation 4.8). Note that here $h$ depends on time, in contrast with the equations for the flow. Only bed load transport $\left(q_{b}\right)$ is taken into account. Here we use a bed load formulation after Komarova and Hulscher (2000) (equation 4.9).

$$
\frac{\partial h}{\partial t}=-\frac{\partial q_{b}}{\partial x}
$$




$$
q_{b}=\alpha\left|\tau_{b}\right|^{b}\left[\tau_{b}-\lambda\left|\tau_{b}\right| \frac{\partial h}{\partial x}\right]
$$

Grain size and porosity are included in the proportionality constant $\alpha$, the grain size is described as uniform. $\tau_{b}$ is the shear stress at the bottom, $h$ is the bottom elevation with respect to the mean water depth $H$ and the constant $\lambda$ takes into account that sand is transported more easily downhill than uphill. $\lambda$ is related to the angle of repose. For more details, we refer to Komarova and Hulscher (2000) and Van den Berg and Van Damme (2006).

Using the assumption of weak nonlinearity, the preferred wave length found in the initial stage stays the preferred wave length in the non-linear stage. The growth to the final shape can then be studied on a fixed domain of one or more of these lengths. Therefore, periodic boundary conditions are used, in the horizontal direction. This means that the values at the inflow and the outflow boundary are equal, which physically means that the modelled sand wave seems to be in between identical sand waves.

In the numerical simulations, the domain of a perturbed bed is transformed to a domain with a flat bed and a flat water surface, such that a rectangular structured grid can be used. The SWC uses an staggered grid, rectangular in the $2 \mathrm{DV}$ plane. The grid is uniform in the horizontal and non-uniform in the vertical to obtain more resolution near the seabed.

Default input parameters are listed in Table 2.3. Some typical output is shown in Figure 2.7, using parameters as listed in Table 2.3, corresponding to the shallow part of transect 2. The final solution is found in two steps. First, the growth in height corresponding to various wave lengths is simulated leading to the wave length that induces the fastest growth in height (fastest growing mode, FGM, Fig. 2.7, left panel). In this example, this is a wave length of $120 \mathrm{~m}$. Secondly, for the FGM a long term simulation finds the final shape for this sand wave, i.e. the sand wave shape that is in equilibrium with the flow and does not change over time anymore (Fig 2.7, middle and right panel). In this case it takes approximately 8 years to reach the final state, with a total wave height around $10 \mathrm{~m}$. In this example, only an oscillating current is taken into account, resulting in a symmetric sand wave (right panel), that does not migrate.

Using these two steps, the SWC is able to predict wave length, height, asymmetry, growth rate and migration. Next, sand wave type variations can be studied using random small initial disturbances in the bed on a larger domain (see Section 2.4.4).

\subsection{Results}

The SWC is used to simulate sand waves for circumstances similar to those affecting the transects described in Section 2.2. Table 2.3 presents the parameters used. In this, $A_{v}$ is taken equal to previous studies in the North Sea (Van den Berg and Van Damme, 2006; Németh et al., 2006) and $S$ is taken slightly higher to include the effect of the larger grain size (see Besio et al., 2004; Hulscher, 

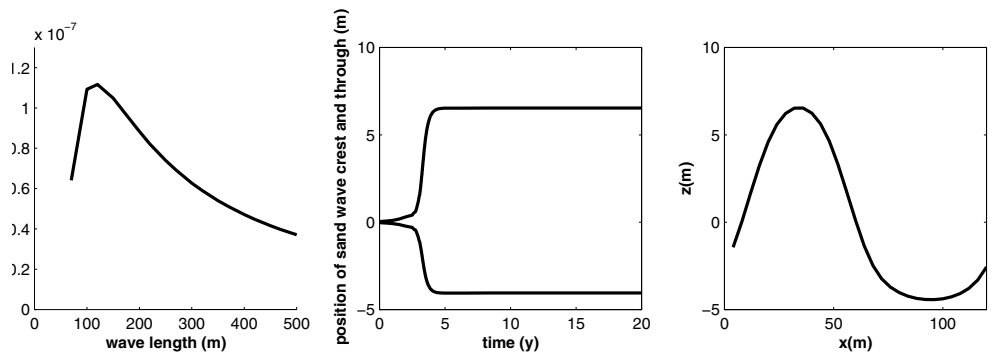

Figure 2.7: Left: prediction of the fastest growing mode, growth in height is largest for a wave length of $120 \mathrm{~m}$. Middle: growth of the crest and trough of the FGM in time. Right: final sand wave form predicted by the Sand Wave Code.

1996; Németh et al., 2007, for more details about $A_{v}$ and $S$ ). The value of $\lambda$ is taken as 1.7, corresponding to an angle of repose of 30 degrees for the sediment. Between the locations on the transects, only the water depth and flow velocity varies. The local flow is estimated using results of $2 \mathrm{DH}$ Delft3D simulations and from the measurements of Cheng and Gartner (1984). Transect 1,2 and 4 are divided into a deep part and a shallow part, to account for the large difference in water depth. For transect 3 only one water depth is used in the simulations because neither the water depth nor the sand waves show large differences over the transect.

First, the influence of the oscillating and unidirectional flow component is investigated, to find out how well a simplified description is able to predict the sand wave shape. Next, the robustness of the model results is tested with a sensitivity analysis for $A_{v}, S$ and $\lambda$. Finally, simulations on a longer domain and with random initial bed disturbances investigate the possible variation within a sand wave transect, due to initial conditions.

\subsubsection{Symmetric Forcing}

The first simulations contained only a symmetric oscillating flow and bed load transport. Results are compared with data in Table 2.4 and Figures 2.9-2.12 (with in the upper panel the field measurements and in the middle panel the model results with a symmetric forcing). Due to the choice of the trendline and the filtering, the BTT could only use one sand wave for the separated parts of transect 4 (see Table 2.4, for further detail Van der Mark et al. (2007)). As the sand wave characteristics do not vary too much over this transect, comparison between the data and the model are carried out with the BTT results of the whole transect (see Table 2.2). Note that at this stage the simulations are carried out with domains of only one sand wave. For convenience, i.e. easier comparison with the data, we show multiple sand waves in the Figures 2.9-2.12. Note that the location of the crests compared to the sand wave crests in the field data are arbitrary.

Due to a symmetric forcing, the simulated sand waves are symmetric around 
Table 2.3: Parameter setting for the Sand Wave Code simulations. Where only one value is given, it holds for all transects.

\begin{tabular}{lcc}
\hline parameter & values & unit \\
\hline $\mathrm{A}_{v}$ & 0.03 & $\mathrm{~m}^{2} / \mathrm{s}$ \\
$\mathrm{S}$ & 0.05 & $\mathrm{~m} / \mathrm{s}$ \\
$\mathrm{D}$ & 800 & $\mu \mathrm{m}$ \\
$\lambda$ & 1.7 & - \\
$\mathrm{H}_{\text {wd }}$ & $15-60$ & $\mathrm{~m}$ \\
tr1 deep & 60 & $\mathrm{~m}$ \\
tr1 shallow & 40 & $\mathrm{~m}$ \\
tr2 deep & 60 & $\mathrm{~m}$ \\
tr2 shallow & 35 & $\mathrm{~m}$ \\
tr3 shallow & 15 & $\mathrm{~m}$ \\
tr4 deep & 40 & $\mathrm{~m}$ \\
tr4 shallow & 30 & $\mathrm{~m}$ \\
$\mathrm{U}_{\text {osc }}$ & $0.4-1.4$ & $\mathrm{~m} / \mathrm{s}$ \\
tr1 deep & 1.4 & $\mathrm{~m} / \mathrm{s}$ \\
tr1 shallow & 1.4 & $\mathrm{~m} / \mathrm{s}$ \\
tr2 deep & 1.0 & $\mathrm{~m} / \mathrm{s}$ \\
tr2 shallow & 1.0 & $\mathrm{~m} / \mathrm{s}$ \\
tr3 shallow & 0.45 & $\mathrm{~m} / \mathrm{s}$ \\
tr4 deep & 1.0 & $\mathrm{~m} / \mathrm{s}$ \\
tr4 shallow & 1.0 & $\mathrm{~m} / \mathrm{s}$ \\
$\mathrm{U}_{\text {uni }}$ & $0.3-0.7$ & $\mathrm{~m} / \mathrm{s}$ \\
tr1 deep & 0.7 & $\mathrm{~m} / \mathrm{s}$ \\
tr1 shallow & 0.3 & $\mathrm{~m} / \mathrm{s}$ \\
tr2 deep & 0.5 & $\mathrm{~m} / \mathrm{s}$ \\
tr2 shallow & 0.3 & $\mathrm{~m} / \mathrm{s}$ \\
tr3 shallow & 0.3 & $\mathrm{~m} / \mathrm{s}$ \\
tr4 deep & 0.3 & $\mathrm{~m} / \mathrm{s}$ \\
tr4 shallow & 0.3 & $\mathrm{~m} / \mathrm{s}$ \\
\hline & &
\end{tabular}



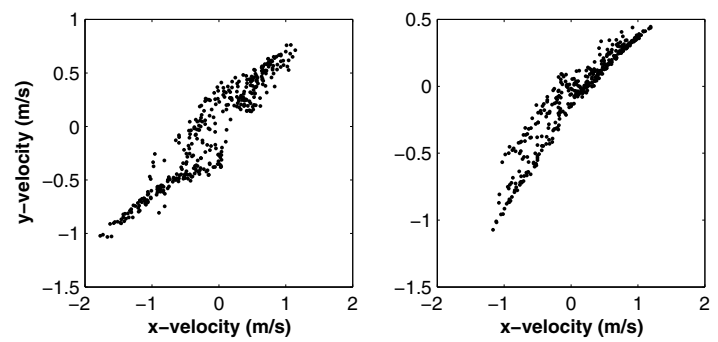

Figure 2.8: Tidal ellipses from transect 1, for one month, from $2 \mathrm{DH}$ simulations in Delft3D. Flow velocity components for the deep (left) and shallow (right) end of transect 1 .

the crest and do not migrate, in contrast to the measured waves. However, asymmetry does occur around the horizontal axis, resulting in differences between the trough and the crest. All results show longer troughs and shorter crests.

We observe that the sand wave height is not simulated realistically in these simulations, i.e. with only sinusoidal tides. Sand waves grow on all transects higher than observed, even up to $60 \%$ of the water depth on the shallow transect 3. At most transects, predicted sand wave heights are about $30 \%$ of the water depth. When focussing on the wave length a less negative view arises. With one exception (i.e. the shallow part of transect 2, where the wave length is in range with the observed wave length), simulated lengths are overpredicted but in the order of magnitude of the measured lengths.

\subsubsection{Asymmetric Forcing}

In the symmetric simulation results, both shape and height of the simulated sand waves differ from the measured data. When investigating the tidal ellipses, resulting from the 2DH Delft3D modelling of the San Francisco Bay, we see that these ellipses are not symmetrical but shifted (Figure 2.8). Besides the oscillating flow, there is another flow component. To simulate this, a constant flow component is implemented in addition to the oscillating flow component. To estimate the constant flow component, maximal flow in both directions were estimated. From this the $U_{\text {osc }}$ was determined as the smallest value of these two and $U_{u n i}$ is determined as the difference between the two values. For example, the maximum flow velocities for the shallow part of transect 1 are $1.3 \mathrm{~m} / \mathrm{s}$ and $1.6 \mathrm{~m} / \mathrm{s}$ (Figure 2.8), leading to an oscillating flow component of $1.3 \mathrm{~m} / \mathrm{s}$ and an unidirectional flow component of $0.3 \mathrm{~m} / \mathrm{s}$. Table 2.3 shows the values for all transects.

Table 2.4 and Figures 2.9-2.12 show the results of the simulation including the additional unidirectional flow component (lower panels). Both shape and height of the simulated sand waves represent the measurements significantly better than the symmetric simulations. In all cases the predicted sand wave lengths are closer to the observed wave lengths, and the simulated asymmetry 
Table 2.4: Results from field measurements combined with results from the Sand Wave Code. 'Sym' lists results of the symmetrical case, 'Asym' list the results of the asymmetric case. '*' means the same as the mean, as in this transect BTT could only use the characteristics of 1 sand wave. Model input paramerters are shown in table 2.3.

\begin{tabular}{lccc}
\hline profile & Hwd & $\begin{array}{c}\text { Hsw } \\
{[\text { min mean max }]}\end{array}$ & $\begin{array}{c}\text { Lsw } \\
{[\text { min mean max }]}\end{array}$ \\
\hline 1 BTT & 40 & $1.8 ; 2.5 ; 3.2$ & $50 ; 53 ; 60$ \\
1 Sym & 40 & 13 & 150 \\
1 Asym & 40 & 3.9 & 70 \\
1 BTT & 60 & $3.5 ; 4.9 ; 7.1$ & $80 ; 92 ; 110$ \\
1 Sym & 60 & $4-11$ & 270 \\
1 Asym & 60 & 3.0 & 100 \\
\hline 2 BTT & 35 & $0.9 ; 2.1 ; 4.3$ & $60 ; 158 ; 260$ \\
2 Sym & 35 & 11 & 120 \\
2 Asym & 35 & 3.7 & 70 \\
2 BTT & 60 & $2.6 ; 4.1 ; 5.3$ & $80 ; 95 ; 120$ \\
2 Sym & 60 & 20 & 250 \\
2 Asym & 60 & 3.5 & 100 \\
\hline BTT & 14 & $0.5 ; 0.6 ; 0.8$ & $15 ; 21 ; 25$ \\
3 Sym & 15 & 9 & 70 \\
3 Asym & 15 & 2.8 & 50 \\
\hline 4 BTT & 33 & $1.7 ; * ; *$ & $70 ; * ;$ \\
4 Sym & 30 & 9 & 100 \\
4 Asym & 30 & 2.9 & 50 \\
4 BTT & 37 & $2.2 ; 2.5 ; 2.7$ & $85 ; 100 ; 115$ \\
4 Sym & 40 & 14 & 150 \\
4 Asym & 40 & 3.7 & 70 \\
\hline
\end{tabular}



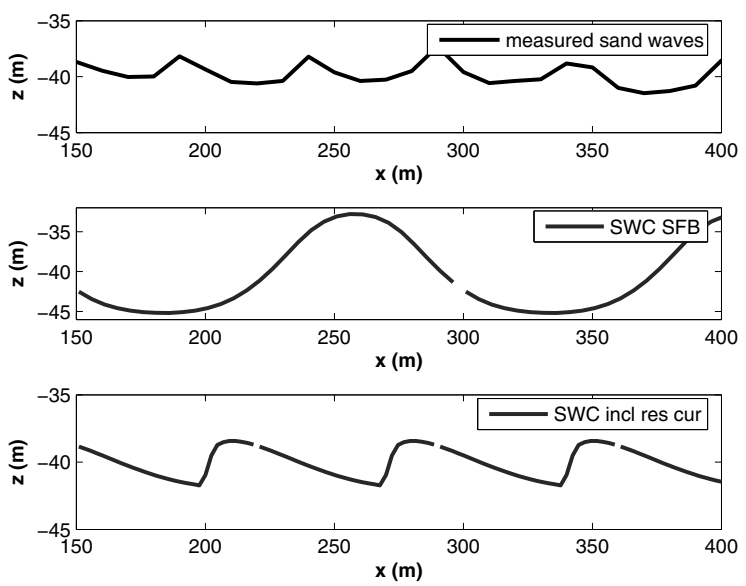

Figure 2.9: Measured and modelled sand wave shapes for the shallow part of transect 1. The highest panel shows the measured bed level, the middle panel the final state of the basic simulation and the lower panel the final state of the simulations including $U_{\text {uni }}$.

approximates to the observed asymmetry. Also striking is the lowering of the sand wave height to realistic values. Table 2.4 shows that all results now are in the same order of magnitude. The only exception is transect 3 , where the sand wave height is still five times the observed height and the sand wave length is about twice as long as in the field. Taking into account the simplifications in the model and its accuracy, the results describe the height and length remarkably well. Both over- and under-estimations occur, but this is always less than $1 \mathrm{~m}$ for sand wave height (excluding transect 3). For the sand wave length only three estimations are outside the measured range; transect 1 deep, 10m longer, transect 3, $25 \mathrm{~m}$ longer and transect 4 shallow $10 \mathrm{~m}$ shorter (compared with the measured data of the whole transect). The estimation errors in the wave length are all within the precision of the model simulations. The results are summarized in Figure 2.13.

The residual currents also cause the sand waves to migrate. Due to the relatively large residual current, which is perpendicular to the sand wave crest, the time scale of both growth and migration increase unrealistically. The sand waves grow towards their final shape in approximately $1-2 y$. They migrate in the direction of the residual current, which is perpendicular to the sand wave crest, with more than $150 \mathrm{~m} / \mathrm{y}$. Where the simplified description of the flow is sufficient to predict the sand wave morphology, the sand wave dynamics are overpredicted.

One could argue that implementing a residual current has the same result as increasing the oscillating flow component on the sand wave morphology. In that case the results perhaps do not improve due to the unidirectional component but 

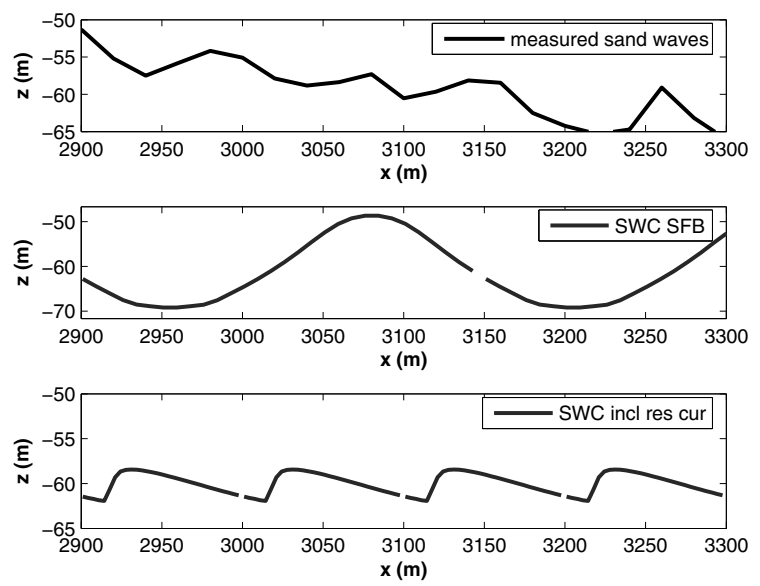

Figure 2.10: Measured and modelled sand wave shapes for the deep part of transect 2. The highest panel shows the measured bed level, the middle panel the final state of the basic simulation and the lower panel the final state of the simulations including $U_{\text {uni }}$.
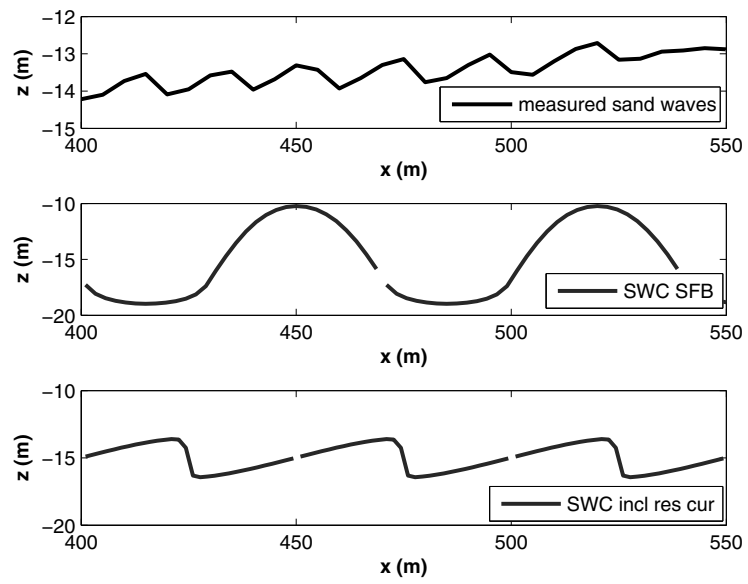

Figure 2.11: Measured and modelled sand wave shapes for transect 3 . The highest panel shows the measured bed level, the middle panel the final state of the basic simulation and the lower panel the final state of the simulations including $U_{\text {uni }}$.

rather due to a higher flow velocity. Table 2.5 shows the results of simulations where the current was increased by increasing the symmetric component or by increasing the asymmetric component. It shows that asymmetric forcing, i.e. oscillating and a residual current together, considerably decrease both the FGM 

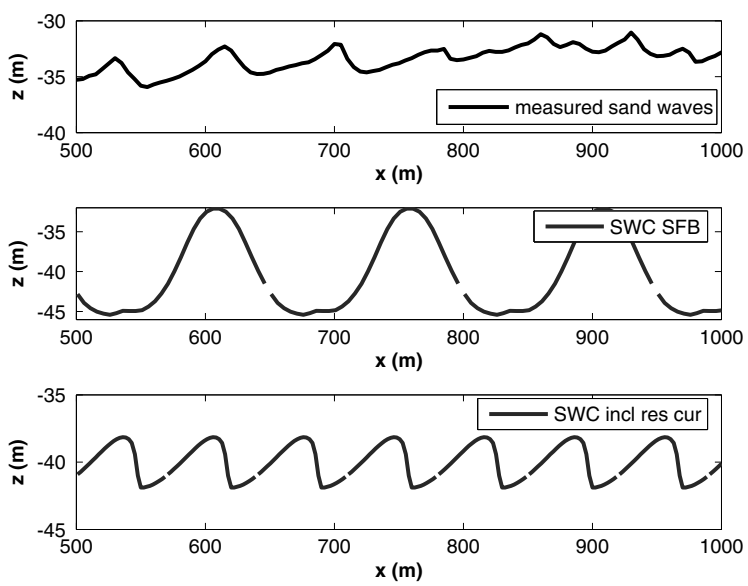

Figure 2.12: Measured and modelled sand wave shapes for the deep part of transect 4. The highest panel shows the measured bed level, the middle panel the final state of the basic simulation and the lower panel the final state of the simulations including $U_{\text {uni }}$.
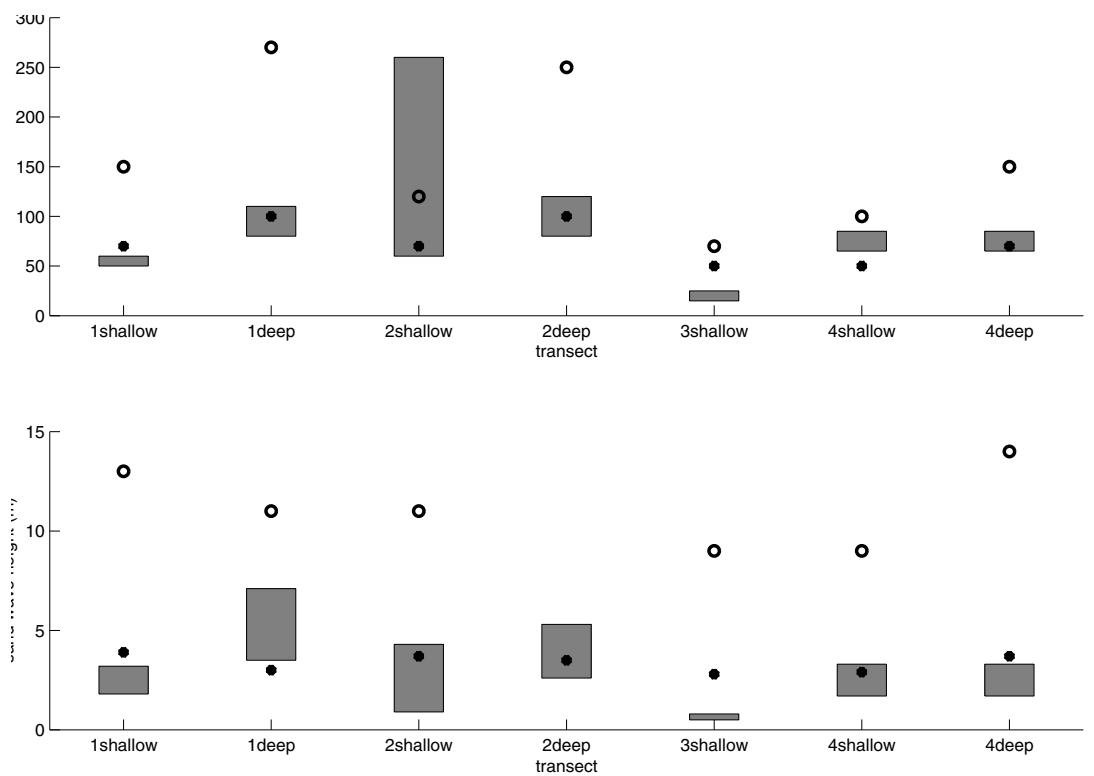

Figure 2.13: Comparison of the symmetric and asymmetric model results with the field data. The open circles represent the symmetric results and closed circles the asymmetric results. The grey bars indicate the rangeof values found in the field data. 
Table 2.5: Results from simulations in which the total current varied by either a symmetric current or a combination of symmetric and residual current. The simulations were carried out for the shallow part of transect 1 . Lsw is the sand wave length, Hsw the sand wave height.

\begin{tabular}{lcccc}
\hline $\begin{array}{l}U_{\text {tot }} \\
{[\mathrm{m} / \mathrm{s}]}\end{array}$ & $\begin{array}{c}U_{\text {osc }} \\
{[\mathrm{m} / \mathrm{s}]}\end{array}$ & $\begin{array}{c}U_{\text {uni }} \\
{[\mathrm{m} / \mathrm{s}]}\end{array}$ & $\begin{array}{c}\text { Lsw } \\
{[\mathrm{m}]}\end{array}$ & $\begin{array}{c}\text { Hsw } \\
{[\mathrm{m}]}\end{array}$ \\
\hline 1.5 & 1.5 & 0.0 & 150 & 12.1 \\
1.5 & 1.4 & 0.1 & 100 & 6.6 \\
1.7 & 1.7 & 0.0 & 170 & 13.2 \\
1.7 & 1.4 & 0.3 & 70 & 3.8 \\
1.9 & 1.9 & 0.0 & 170 & 12.9 \\
1.9 & 1.4 & 0.5 & 70 & 3.3 \\
\hline
\end{tabular}

and the final wave height. For smaller values of the residual current, this relation is stronger. A small residual current decreases the sand wave height (-50\%) and the sand wave length (-33\%). Larger residual currents increase this effect though the relative effect becomes smaller. On the contrary, increase of the oscillating current only increases both the sand wave length and the sand wave height, though the changes are small compared to the model accuracy. Hence, besides reproducing the sand wave shape better, we found that a residual current also influences the sand wave length and height considerable.

\subsubsection{Sensitivity Analysis}

We tested the sensitivity of the model results for three model parameters, the viscosity $A_{v}$, the slip parameter $S$ and the slope term $\lambda$. These are the most difficult model values to estimate in a physically realistic way (Németh et al., 2007). Figure 2.14 shows the variation in final sand wave height and length caused by a change of all three parameters. The value of the eddy viscosity $A_{v}$ and the slip parameter $S$ are varied with approximately $60 \%$ of their default value (respectively $0.1,0.3$ and $0.5 \mathrm{~m}^{2} / \mathrm{s}$ and $0.2,0.5$ and $0.8 \mathrm{~m} / \mathrm{s}$ ). This is in the range of realistic values (Hulscher and Van den Brink, 2001; Besio et al., 2004). The slope factor $\lambda$ was taken $1.2,1.7$ and 2.2, corresponding with angles of repose of 40, 30 and 24 degrees.

Figure 2.14 shows that the influence of $A_{v}$ varies between the different transect locations. In general, increasing $A_{v}$ increases the sand wave height. The influence on the sand wave length is less pronounced, but there is a tendency to stay constant with increasing $A_{v}$. This is in agreement with the linear sensitivity analysis carried out by Németh et al. (2002). As the bed shear stress is the dominant factor in the initial sand wave growth, the $A_{v}$ (which mostly influences the effect of changes in the flow on the vertical flow distribution) is of minor importance on the sand wave length. The exception is the deep part of transect 1 . Here, an increase of $A_{v}$ decreases both wave length and wave height. This is most likely due to the combination of the high water depth and the high 
velocity. Both values are on the edge of values where sand waves are expected (Wilkens, 1997). Changing the combination of $A_{v}$ and $S$ will in this case result in circumstances in which sand waves are no longer likely to occur. The large changes in both sand wave length and sand wave height are an indication of this. The increase of $A_{v}$ also increases the sand wave height due to a changing ratio of sand wave height over sand wave length $(\mathrm{H} / \mathrm{L})$. This change in $\mathrm{H} / \mathrm{L}$ is the result of two processes. Firstly, the shear stress, averaged over a tidal cycle, directs sediment to the top. Secondly the slope of the sand wave leads

to sediment transport downhill. As the shear stress equals $A_{v} \frac{\delta u}{\delta z}$ at the bed, an increase of $A_{v}$ will lead to an increase of shear stress, changing the ratio of $\mathrm{H} / \mathrm{L}$. This results in an increase of the sand wave height as the sand wave length stays constant.

Increasing the slip parameter, $S$, results in a decrease of bed shear stress. Both the sand wave length and the sand wave height decrease with an increasing slip parameter (decreasing stress). The decrease in sand wave length can be understood, as increasing stress dampens the smaller wave length more effectively. Decreasing this stress allows these smaller wave lengths to grow, which agrees again with Németh et al. (2002). The decrease in sand wave height is the result of a combination of two processes. Firstly, due to the shorter sand wave lengths, sand waves grow lower due to the constant $\lambda$. On the other hand an increase of roughness results in higher sand waves. This combination results in lower sand waves, while the ratio of height and length increases.

Changing $\lambda$ is of minor importance to the model results according to Figure 2.14. Increasing $\lambda$ means that the angle of repose will decrease such that the ratio between sand wave height and length decreases. As increasing $\lambda$ dampens shorter waves, increasing $\lambda$ results in slightly longer sand waves. The sand wave height is determined by the value of height over length mostly and balances the change of the wave length. This leads to an increase in the wave length, except for transect 3. The wave height also increases, with only a few exceptions.

The sensitivity to both $A_{v}$ and $S$ is largest on the deep part of transect 1, for reasons explained earlier. For the other transects variation is clearly visible. The value of $\lambda$ seems to be of minor importance. Changing these model parameters does not produce drastic changes in the results. The order of magnitude of both sand wave length and sand wave height stays the same.

\subsubsection{Random Initial Bed Perturbation}

All previous runs started with a domain of one sand wave length, corresponding with the FGM, with a sinusoidal initial small bed perturbation. This allows us to study the evolution of a single sand wave, while fixing its wave length. It gives insight in the variation between locations, caused by variation in the processes such as flow velocity and water depth. However, this approach can not study the possible wave length evolution and the interaction between adjacent sand waves. To investigate these two aspects, Figure 2.15 shows three runs on larger domains starting from random initial bed perturbations, with a maximal amplitude of $0.1 \mathrm{~mm}$. Parameters correspond to the shallow part of transect 1 . 

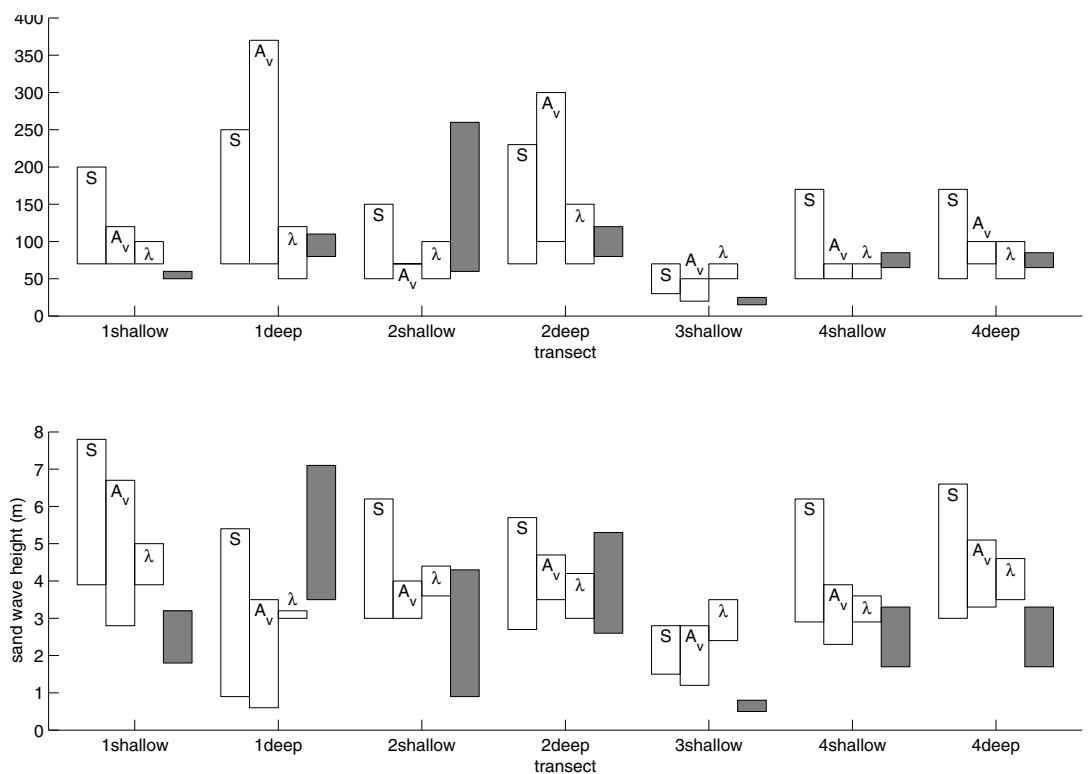

Figure 2.14: The influence of varying $A_{v}, S$ and $\lambda$ on the model results compared with the field data (grey bar). The top panel shows the effects on the sand wave length, the lower panel shows the effect on the sand wave height.

Figure 2.15 shows the possible sand wave variation within a location. The initial conditions can lead to various sand wave transects, in which the overall characteristics are comparable. A disadvantage of this long domain simulations is that the simulations finally evolve to one large bedform, of the length of the model domain. This is caused by the fact the large waves are not totally damped but show a small but positive growth rate. In a long domain they will, in the long term overtake the smaller sand waves. At this moment the only way to overcome this weakness is to reduce the model domain to the length of the FGM. This topic is left for future research. Note that, Figure 2.15 shows the results before the final stage.

Due to the large domain, sand waves tend to grow both higher and longer, though in wave length this mainly means lengthening of the troughs while the crest length stays roughly the same for the three runs.

\subsection{Discussion}

The addition of the unidirectional current exerts a strong influence on the dimensions and shape of the sand waves. In the idealized SWC, the simple combination of a symmetric and a residual current already predicts the sand wave morphology well. It seems sufficient to split the flow into these two components, and not include the precise tidal constituents. This coincides with Németh et al. 

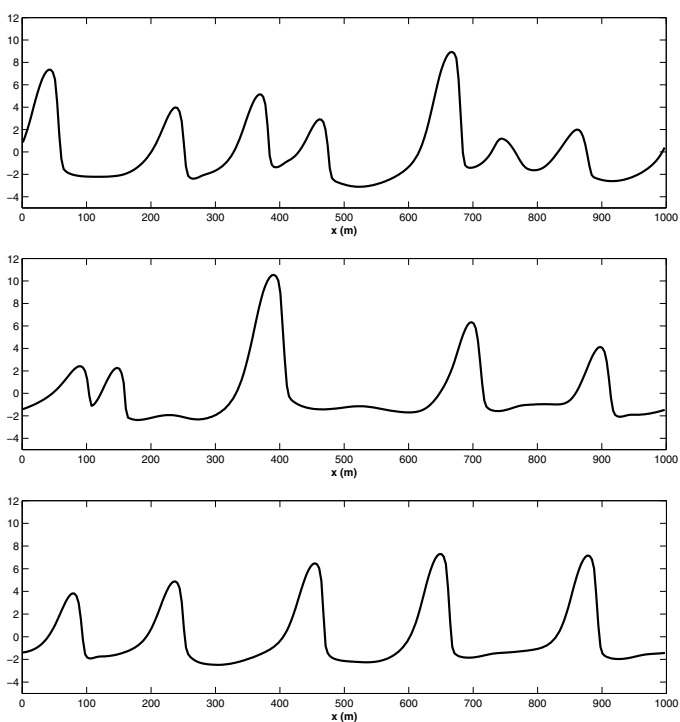

Figure 2.15: Result the Sand Wave Code simulations on larger domains, with random initial disturbances of the order of $10^{-4} \mathrm{~m}$. The shown profiles are not in their final state.

(2002), where the $M_{0}$ and $M_{2}$ are assumed to give the largest contributions to the tidal system. Further investigations which incorporate higher harmonics should test this expectations, including the effects on sand wave dynamics.

Although flow separation is not included in the SWC or model, it is possible that flow separation occurs on these sand waves in some locations and at some times. Due to the relatively strong included unidirectional current, the lee slopes in transect 3 and the shallow part of transect 1 became steeper than the 14 degrees that is needed for flow separation (around 30 and 15 degrees respectively)(Paarlberg et al., 2006). The other locations show slopes around 8-12 degrees. Paarlberg et al. (2007) show that flow separation in the case of river dunes can be parameterized and modeled such that the separation streamline is captured well. As river dunes occur in purely unidirectional flow, here flow separation is a main issue when describing the flow-bed interaction. As Paarlberg uses the same model as used in this thesis (Van den Berg and Van Damme, 2006), their parameterization could be included if observations would show the occurrence of flow separation over the steeper Golden Gate sand waves. Still, the present results predict the sand wave morphology well, and confirm the underlying hypothesis of residual circulation cells as the main process for sand wave occurrence. If flow separation does occur on these sand waves, the effects maybe limited to influencing the detailed shape of the sand waves, particularly near the crests, as well as the sediment transport due to smaller superimposed bedforms in this region.

When comparing the model results with the data, one should remember the 
model is idealized and accuracies in the sand wave height and length are around $15 \%$, due to possible instabilities in the final shape, and around $20-30 \mathrm{~m}$. Also Section 2.4.4 shows that variation in the field occurs easily, while in the model, using one wave only, this variation is not taken into account. Though results in Section 2.4.4 are not realistic in the sense that sand waves grow too large, they give a good indication of the possible variation over the area due to random initial conditions. More variation is likely to occur because of the ever present natural random fluctuations. This variation can not yet be properly included in the model without greatly increasing the computation time. Regarding this model background, the results compare reasonably well with the data. When transect 3 is excluded both the predicted sand wave length and the predicted sand wave height are in range with the observed values (Figure 2.13). Small over and small under estimations exists, but these are all in range of the model accuracy.

Though the SWC results are influenced by varying the value of $A_{v}, S$ and $\lambda$ this influence is of minor importance compared to the range in predictions possible over the whole area, i.e. the variation that exists between the transects. Even though the variation in circumstances over San Francisco Bay are large, predictions with the default values were reasonable over the whole area. It is worth mentioning that the model parameters were not tuned to fit the data. General values are used for $A_{v}, S$ and $\lambda$. The sensitivity analysis further shows that the model results are robust for a range of these values.

For transect 3, the model results compare significantly less well to the observations than for the other transects. We used a grain size of $800 \mu \mathrm{m}$, corresponding to typical measurement on the seabed surface on transect 0 . However, grain size varies substantially in the region. Especially in transect 3 we can expect smaller grain sizes as measurements closer to the coast show smaller grains. This might lead to a smaller value of $S$, which would lead to larger sand waves (Fig. 2.14) and would not solve the difficulties the model has on this transect. The residual current estimation might be another cause of errors. Transect 3 is located in a region with particularly complex waves and currents. A reversing counter-flow eddy is frequently present in the vicinity of transect 3. In addition, the steep bathymetric slopes and strong jet-like currents in the region cause complex surface wave patterns, with sharp gradients in wave characteristics. Runs for transect 3, with different residual currents, showed that increasing the residual current reduces both the sand wave length and height (e.g. for a residual current of $0.5 \mathrm{~m} / \mathrm{s}$ sand wave height and length are 30 and $1.6 \mathrm{~m}$ respectively). However, this increase in flow conditions to fit the observed data is beyond the expected values of both the residual current and the maximal flow velocity. Another possible reason for the misprediction on transect 3 is that due to the shallower water, wind and short waves have more impact on the seabed, changing the bedforms. Research on the influence of surface gravity waves shows that they can lower the sand wave heights significantly (Chapter 3 or Sterlini et al., 2009a).

The sand waves in San Francisco Bay are located on the edge of a large ebb tidal delta. The unusual bed slope might affect the migration of sand waves 
and their shape. While the sand wave shape indicates potential migration in the seaward direction, the slope due to the ebb tidal delta may counteract this potential migration.

The model results in this chapter include bed load sediment transport only. In most cases this is a good assumption, however, on transect 1 and 2 it is likely that suspended sediment transport takes place, due to the high velocities during peak tide $\left(w_{s} / u_{*}\right.$ is smaller than 1$)$. Note that these high velocities only occur during a part of the tidal cycle (figure 2.4). Further research is under way concerning the influence of suspended sediment transport on the sand wave morphology and dynamics. First results indicate that the inclusion of suspended sediment slightly lowers and shortens the sand waves. In addition their shape changes towards more trough-crest asymmetry; the trough becomes longer and the crest shorter. This coincides with field observations. The overall results of the model without suspended sediment are not changed qualitatively.

\subsection{Conclusions}

In this chapter we present a detailed comparison between sand wave data and the non-linear sand wave model. The main question in this chapter is: "an we explain sand wave variation between locations with different forcing conditions using a simplified non-linear model?".

The results of the model simulations show that the sand wave code is able to describe the variation in the Golden Gate sand waves well. The results of the Sand Wave Code compare reasonably well with the observed sand waves when both an oscillating and a residual current are taken into account. Except for transect 3, it seems enough to implement this forcing and bed load sediment transport to find the sand wave height, length and shape close to the observed values for the different locations. Current together with water depth seem to be the most important factors influencing sand wave characteristics. To model wave length, height and shape correctly it is crucial to include the local residual current. Though the value of both the constant eddy viscosity and the slip parameter influence the wave length and height, they do not improve or deteriorate the comparison with the field measurements.

Large-domain simulations give an indication of the possible variation within a single transect. However, in these large domain simulations no final state could be established.

The simulation results give further confidence in the underlying hypothesis and assumptions. The feedback mechanism between the bedforms and the tidal flow seems to be the leading process. The assumption that the sand waves are weakly non-linear, i.e. we can use the preferred wave length from the linear regime, seems justified by the good comparison of the model results with the highly variable field data. 


\title{
Chapter 3
}

\section{Modelling the effect of surface waves on offshore sand waves}

\begin{abstract}
Offshore sand waves are bed patterns that occur in shallow seas. Because of their dimensions such as their height (1-10m), length (100-800m) and migration rate $(1-10 \mathrm{~m} / \mathrm{y})$, they can influence human activities in shallow seas. In this chapter we present a first investigation on the effect of surface gravity waves on fully grown sand waves. We add surface wave effects to a non-linear sand wave model to investigate how surface waves influence the sand wave evolution. We show that surface waves are able to lower the modelled sand wave heights and to cause migration in the direction of the waves. The quantitative effect depends both on the surface wave characteristics (more effect for larger waves or higher occurrence) and the sand wave environment (more effect in shallow water and for small tidal velocities). The simulations show that surface waves can significantly influence the sand wave fields and that including them in the model improves the predictions.
\end{abstract}

\subsection{Introduction}

\subsubsection{Sea Bed Sand Waves}

Offshore sand waves are bed patterns that occur in shallow seas (Figure 3.1). The wavelengths of these bed forms vary between 100 and 800 metres, and heights can reach up to one third of the water depth (i.e. a maximum of around 10 metres in 30 metres of water). These characteristics, together with the fact that sand waves can migrate several metres per year and that they cover the majority of e.g. the Southern North Sea (Van der Veen et al., 2006), mean that they affect human activities in shallow seas. Therefore, we aim to model, and with that better understand, the morphology and dynamics of these sand waves.

\subsubsection{Surface Waves}

Offshore in shallow seas, under normal conditions, short surface waves rarely interact with the sea bed. As the water depth is in the order of tens of metres, sediment is mainly transported as bed load with the tidal currents. However, during storms, surface gravity waves (referred to hereinafter as surface waves or waves) are considered to initiate the stirring of sediment, such that the sediment transport by the tidal currents increases if surface wave energy increases. This 


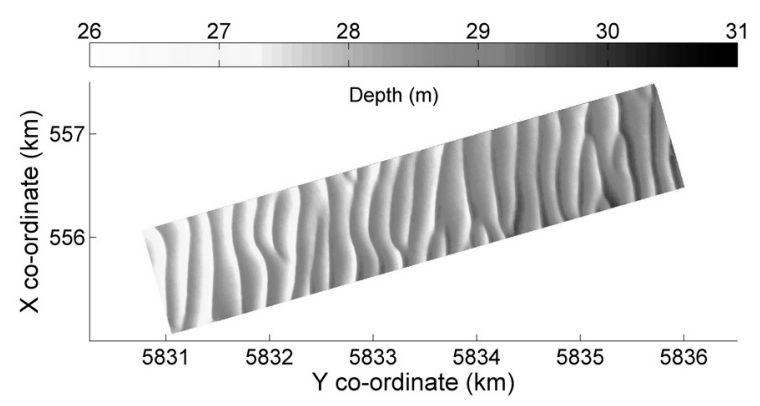

Figure 3.1: Sand wave patch as observed in the Southern part of the North Sea.

occurs especially in the relatively shallower water e.g. closer to the coast, or on the crests of sand banks. In this case the surface waves might affect sand wave shapes or their migration speed. Field observations confirm this hypothesis. For example Passchier and Kleinhans (2005) concluded that the sand wave morphology close to the coast of the Netherlands is a function of the general surface wave climate.

In return, surface waves might also be affected by the sand waves. This can happen due to a changing water depth, but also indirectly by locally changing the tidal current. If we take into account that sand waves can significantly change both the local water depth and, through this, the current velocity (Hennings et al., 2000), surface wave characteristics are expected to change over sand waves. Though the effect of surface waves is incorporated in a few linear studies of sea bed morphodynamics (e.g. Blondeaux and Vittori, 2005b), a non-linear investigation on its effect on sand waves, i.e. including sand wave heights, has not yet been accomplished.

\subsubsection{Goal}

In this chapter we present a first investigation of the effect of surface waves on the actual shape of sand waves. The main question is "can surface waves affect the sand wave characteristics, and if so, under which conditions and to what extent?". To answer this question, we model surface wave effects in an idealized non-linear sand wave model, focussing on the non-linear final sand wave shape. The surface wave effects are investigated under different environmental conditions (water depth and tidal oscillating velocity). Subsequently, we compare the model results with field observations and investigate the possible physical processes underlying the surface wave effects.

The chapter is organized as follows. We start by describing the general sand 


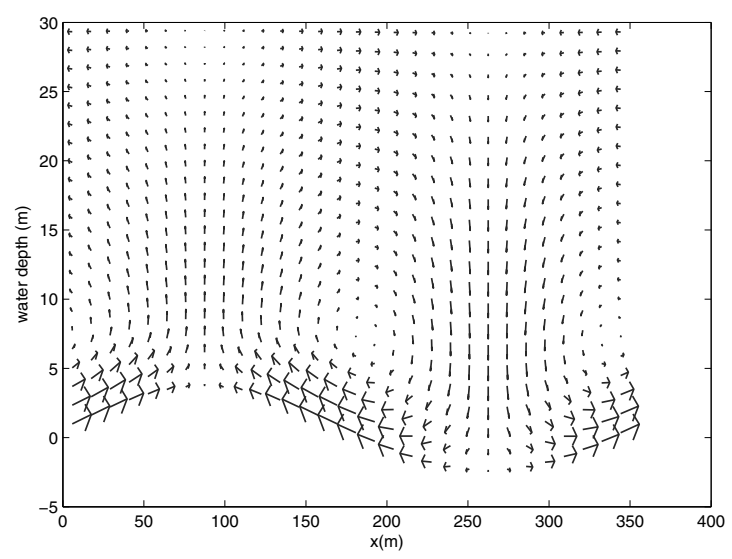

Figure 3.2: Residual circulation, averaged over a tidal cycle. In this unstable case the cells, formed due to the interaction between the flow and the bed perturbation, will lead to growth of the bed perturbation.

wave model and the extensions made to include the surface waves. In Section 3.3 the results are presented, including a case study to compare model results with field observations. Discussion of the results and conclusions follow in Section 3.4 and Section 3.5 respectively.

\subsection{Model Approach}

In this section we briefly describe the background of the sand wave model (Section 3.2.1), for further details we refer to Van den Berg and Van Damme (2006) and Van der Meer et al. (2007). Section 3.2.2 deals with the inclusion of surface wave effects in the Sand Wave Code (SWC).

\subsubsection{Sand Wave Model}

The Sand Wave Code (SWC) used in this project is based on an idealized model by Németh et al. (2006) and further developed by Van den Berg and Van Damme (2006). It is a two dimensional vertical model, which is developed specifically to describe sand wave evolution from its generation, to its fully grown state. The SWC has shown good results in describing the wavelength, height, shape characteristics and migration for sand wave fields in the Southern part of the North Sea (Van den Berg and Van Damme, 2006; Németh et al., 2007, 2006) and near the Golden Gate Channel (Sterlini et al., 2009b).

Sand wave formation is explained as self organisation due to interaction between a sandy seabed and a tidal flow. Sand waves occur as free instabilities in this system, i.e. there is no direct relation between the scales related to the forcing (tide) and those related to the morphological feature (sand wave) (Dodd et al., 2003). Sand wave occurrence can be understood only if the feedback mechanism 
between the forcing and the seabed is taken into account. Hulscher (1996) described this mechanism of self organization for sand waves, where residual vertical vortices play a crucial role. In short, the process is as follows. Starting from a flat bed with an oscillating current, adding small perturbations of the sea floor cause small perturbations in the flow field and vice versa. The bed can be either stable, which means that all bed perturbations will be damped, or unstable, which means that certain bed perturbations will grow. If perturbations are unstable the flow field is changed such that, averaged over the tidal cycle, small vertical residual circulation cells occur (Fig. 3.2). These cells cause a small net transport over a tidal cycle directed towards the crests of the perturbation, thereby causing growth of the perturbation. Depending on the circumstances such as flow velocity and water depth, perturbations with different lengths will show different growth/decay rates. The fastest growing mode is the perturbation which triggers the fastest initial growth. For small amplitude perturbations, growth can be described as linear, though as sand waves grow larger, nonlinear effects become important. However, there are several indicators that seem to imply that sand waves are only weakly non-linear: their amplitude is generally smaller than $20 \%$ of the water depth and the predicted fastest growing wave length (growth in height) is close to the observed wave length. Assuming weak non-linearity, the initially dominating wavelength will be close to the one dominating in the non-linear regime. Subsequently, the fastest growing mode provides the dominant sand wavelength, which is found to be close to the dominating one in reality for weakly non-linear systems (Dodd et al., 2003).

For different wave lengths we calculate the growth rate from the results of the simulations, which gives us the fastest growing mode (FGM). The SWC simulates the growth for this wave length from the initial small amplitude disturbance to the final sand wave shape, i.e. the shape that is in equilibrium with the flow. The SWC consists of the hydrostatic flow equations for $2 \mathrm{DV}$ flow. As the slopes of the sand waves are fairly mild, i.e. only a few degrees, flow separation is not expected to occur and therefore not included in the model (flow separation occurs for slopes steeper than 14 degrees, see Paarlberg et al. (2006) and references therein). The tidal flow is modelled as a sinusoidal current prescribed by means of a forcing. Boundary conditions at the bed disallow flow perpendicular to the bottom. Furthermore, a partial slip condition compensates for the constant eddy viscosity, which is known to overestimate the eddy viscosity near the bed. At the water surface there is no friction and no flow through the surface. Since the flow changes over a timescale of hours and the morphology over a timescale of years, the bathymetry is assumed to be invariant within a single tidal cycle. The flow and the sea bed are coupled through the continuity of sediment. Note that here the bathymetry depends on time, in contrast with the calculations for the flow. Only bed load transport is taken into account, following Komarova and Hulscher (2000). For equations we refer to Van den Berg and Van Damme (2006) and Chapter 2. 


\subsubsection{Surface Waves}

As sand waves occur in relatively deep water with respect to surface waves, the surface waves are not expected to break. However, waves can break and even be blocked and swept back in the relatively deep water over the sand wave due to an opposing current. To implement the main effect of surface waves we exclude this wave breaking and use linear wave theory, i.e. monochromatic waves for which the linear approximation holds $\left(a k \ll 1, a / h \ll 1\right.$ and $a /\left(k^{2} h^{3}\right) \ll 1$, where $a$ is the surface wave amplitude, $k$ the wavenumber and $h$ the local water depth). We assume that the waves and current are collinear. The absolute frequency of the waves, $\omega$, is assumed to be constant and the wave action, $\frac{E}{\sigma}$, is a conserved quantity, where $\sigma$ is the intrinsic frequency. Furthermore we assume that the currents influence the wave characteristics, while the waves do not influence the currents $(\mathrm{Mei}, 1999)$. This means the waves can be included in the model as an additional shear stress at the sea bed. With a given incoming wave period the wave number is calculated using (3.1). Knowing the wave number $k$, we can find the wave energy per location over the sand wave using (3.2). The product $U k$ in (3.1) represents the Doppler effect, which holds especially for small wave periods and high current velocities.

$$
\begin{gathered}
\omega=U k+\sqrt{g k \tanh k h} \\
\frac{d}{d x}\left(\left[U+C_{g}\right] \frac{E}{\sigma}\right)=0 \\
C_{g}=\frac{\sigma}{2 k}\left(1+\frac{2 k h}{\sinh (2 k h)}\right) \\
\omega=\frac{2 \pi}{T}
\end{gathered}
$$

Here $U$ is the depth averaged current velocity, $g$ the gravitational force and $\mathrm{E}$ the wave energy density. The group velocity and the wave period of the surface waves are represented by $C_{g}$ and $T$ respectively. With (3.5) we find the surface wave height $H_{w}$. With this wave height the shear stress at the bed due to the surface waves is defined using the wave orbital velocity (Equations 3.6 and 3.7).

$$
\begin{gathered}
E=\frac{1}{8} \rho g H_{w}^{2} \\
u_{w}=\frac{\omega H_{w}}{2 \sinh (k h)} \\
\tau_{b w}=\frac{1}{2} f_{w} u_{w}^{2} \\
f_{w}=\exp \left(-6+5.2\left(\frac{a}{2.5 D_{50}}\right)^{-0.19}\right)
\end{gathered}
$$

The flow velocity due to the surface waves just above the bed is denoted by $u_{w}, \tau_{b w}$ is the bed shear stress due to $u_{w}, f_{w}$ is the bed friction factor according 
to Swart (1974), $a$ is the surface wave amplitude (equal to half of $H_{w}$ ) and $D_{50}$ is the median grain size. Note that we use the volumetric bed shear stress and a constant grain size. We include both the effect of currents and wave shear stresses on sediment transport, $q_{b}$ : see (3.9). This causes an extra transport by the tidal flow and affects the slope adjustment, both due to the stirring effect of the surface waves:

$$
\begin{gathered}
q_{b}=\alpha\left|\tau_{b f}\right|^{1 / 2}\left(\left|\tau_{b f}\right|+\gamma\left|\tau_{b w}\right|\right)\left(\frac{\tau_{b f}}{\left|\tau_{b f}\right|}-\lambda\left|\tau_{b f}\right| \frac{d h}{d x}\right) \\
\tau_{b f}=\left.S u\right|_{b e d}
\end{gathered}
$$

In (3.9) we follow Calvete et al. (2001); Roos et al. (2004) and Van Rijn (1993), here rewritten for a depth dependent situation, i.e. for the bed shear stress $\tau$ instead of the depth averaged velocity $u$. The derivation of Equation 3.9 is included in Appendix 3.5. The bed load sediment transport and the bed shear stress due to the current are represented by $q_{b}$ and $\tau_{b f}$ respectively. The bed shear stress due to the current, $\tau_{b f}$, follows from (3.10), with $S$ the slip parameter. The constant $\alpha$ has a value of $0.3 \mathrm{~s}^{2} / \mathrm{m}, \lambda$ is related to the angle of repose and $\gamma$ is an dimensionless parameter with value 1 (see Appendix).

\subsection{Results}

For the simulation of the surface wave effects on sand waves, typical North Sea parameter values are chosen (Table 3.1). Table 3.2 shows the used surface wave heights and periods. To cover different wave types, wave heights and periods are used with different probabilities of exceedance. The values correspond to the wave climate at the IJmuiden Munition Dump (Southern North Sea, average water depth $21 \mathrm{~m}$ ), as investigated by de Leeuw (2005), using online available wind and wave data measured between 1979 and 2001 (RIKZ, 2004).

In Section 3.3.1 the effect of surface waves is investigated including continuous wave conditions. Though this is not realistic, it gives an indication of the shape that sand waves grow towards during rough conditions. The effect of water depth and current speed (symmetric and asymmetric, including a residual current) is also studied in this section. Next, in Section 3.3.2 waves are included with their probability of occurrence. Here the effects are more correlated to surface wave effects in reality. Finally in Section 3.3.3 the model results are tested in a case study, representing two locations in the North Sea. A combination of different surface waves is used to simulate a varying surface wave climate.

\subsubsection{Including Surface Waves}

The surface wave effects for different surface wave climates (see Table 3.2) are tested for two water depths $(15 \mathrm{~m}$ and $30 \mathrm{~m})$ and two M2-velocities $(0.5 \mathrm{~m} / \mathrm{s}$ and $1.0 \mathrm{~m} / \mathrm{s})$. Small surface waves hardly change the FGM and for larger surface waves we assume they do not influence the sand wave length as these surface waves only occur in short durations, while the change in sand wave length is a 
Table 3.1: Parameter settings for the model runs, typical for the Southern part of the North Sea.

\begin{tabular}{lccc}
\hline Physical quantity & Parameter & Value & Dimension \\
\hline water depth & $h$ & $15-30$ & $\mathrm{~m}$ \\
tidal velocity & $U$ & $0.5-1.0$ & $\mathrm{~m} / \mathrm{s}$ \\
eddy viscosity & $A_{v}$ & 0.01 & $\mathrm{~m}^{2} / \mathrm{s}$ \\
slip parameter & $S$ & 0.008 & $\mathrm{~m} / \mathrm{s}$ \\
slope parameter & $\lambda$ & 1.7 & - \\
\hline
\end{tabular}

Table 3.2: Parameter settings for the surface waves, corresponding to the IJmuiden Munition Dump in the Southern North Sea (21m water depth).

\begin{tabular}{lcc}
\hline $\begin{array}{l}\text { Probability of } \\
\text { exceedance [\%] }\end{array}$ & $\begin{array}{c}\text { surface wave } \\
\text { height }[\mathrm{m}]\end{array}$ & $\begin{array}{c}\text { surface wave } \\
\text { period }[\mathrm{s}]\end{array}$ \\
\hline 100 & - & - \\
50 & 1.0 & 5.3 \\
10 & 2.4 & 7.0 \\
1 & 4.2 & 8.9 \\
0.1 & 5.5 & 10.7 \\
\hline
\end{tabular}

slow process. Therefore, for all surface wave cases the sand wave length of the FGM of the case without surface waves is maintained. Figures 3.3 and 3.4 show the results for the shallow water $(15 \mathrm{~m})$ cases. The upper panel shows the growth in time of the sand wave crest and trough towards their final height/depth, the lower panels show a side view of the final sand wave shape, under increasing wave climates. In all cases the initial sand wave amplitude is $10 \mathrm{~cm}$. Figure 3.5 summarizes the changes in sand wave height with increasing surface waves.

For the $15 \mathrm{~m}$ water depth case, Figure 3.3 and 3.4 show that, for increasing surface waves, the sand wave height is significantly diminished. The changes are largest under large tidal currents, though differences between the flow velocity cases are small. The sand wave height is decreased up to $34 \%$ for the most extreme waves. Even small surface waves, with an exceedance probability of $50 \%$, reduce the sand wave heights by approximately $10 \%$. Note that this holds for continuously present surface waves in all cases. The sand wave shape also changes. The trough becomes smaller, the slopes milder and the crest broader if surface waves increase. The percentage of the sand wave above the mean level of the bed increases from $36 \%(39 \%)$ (no waves) to $51 \%(55 \%)$ (wave height $5.5 \mathrm{~m}$ and period $10.7 \mathrm{~s})$ for the velocity of $0.5 \mathrm{~m} / \mathrm{s}(1.0 \mathrm{~m} / \mathrm{s})$ respectively.

We would like to stress that the oscillations of some simulations in time are numerical artifacts, caused by the choice of the amount of grid points, the time stepping and the migration of the sand waves through the model domain. Changing these factors will change the oscillations, but has no significant effect on the discussed results. 

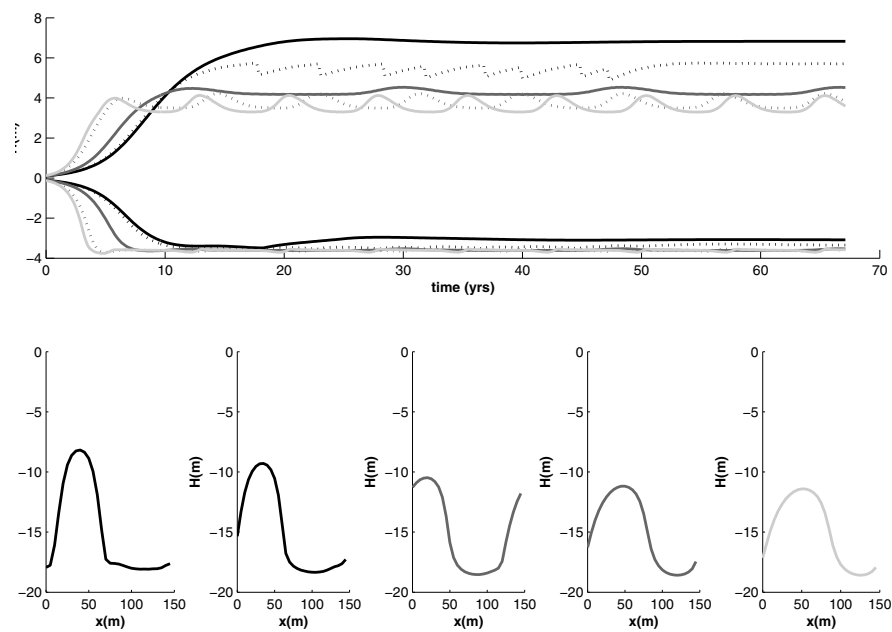

Figure 3.3: Sand wave growth (top) and shape (bottom) for different surface wave characteristics. For the shape figures, from left to right the surface wave period is $0.0 \mathrm{~s}$, $5.3 \mathrm{~s}, 7.0 \mathrm{~s}, 8.9 \mathrm{~s}, 10.7 \mathrm{~s}$ and the height is $0.0 \mathrm{~m}, 1.0 \mathrm{~m}, 2.4 \mathrm{~m}, 4.2 \mathrm{~m}, 5.5 \mathrm{~m}$. Current velocity is $0.5 \mathrm{~m} / \mathrm{s}$ water depth $15 \mathrm{~m}$.

In the $30 \mathrm{~m}$ water depth case (not shown) these oscillations distort the results of some simulations. Therefore we exclude the results of the Hw1T5 case for both the deep water cases. As with the shallow water simulations we see a lowering of the sand wave height for increasing surface waves. The maximum decrease is around $45 \%$ for the low flow velocity case and $37 \%$ for the high flow velocity case. The sand wave shape changes again to a broader crest and and smaller trough.

Figure 3.5 summarizes the changes in sand wave height with increasing surface waves. In all cases the sand wave height decreases rapidly when surface waves increase. The effect of the flow velocity of the oscillating tidal current and water depth is not clear. In shallow water the surface waves decrease the sand wave height slightly more for higher velocities. In deep water the opposite occurs.

Besides the changes in shape, the surface waves also cause migration in the direction of the surface waves. This is caused by the interaction between the M2 tide and the surface waves. In combination with the symmetric tidal current, the wave characteristics are changed depending on whether they propagate with or against the currents. The transport in the two directions is therefore different as there is more or less sediment stirred by the surface waves. Therefore sand wave migration increases with increasing surface wave heights and periods. Without the surface waves, no migration occurs, due to the symmetric oscillating current. Increasing the surface waves increases the sand wave migration. For example for 

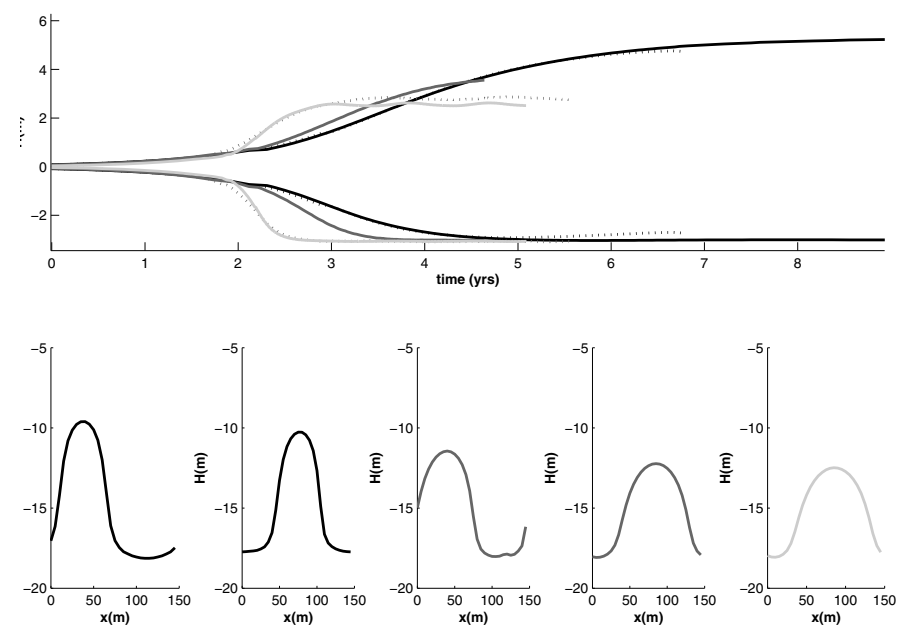

Figure 3.4: Sand wave growth (top) and shape (bottom) for different surface wave characteristics. For the shape figures, from left to right the surface wave period is $0.0 \mathrm{~s}$, $5.3 \mathrm{~s}, 7.0 \mathrm{~s}, 8.9 \mathrm{~s}, 10.7 \mathrm{~s}$ and the height is $0.0 \mathrm{~m}, 1.0 \mathrm{~m}, 2.4 \mathrm{~m}, 4.2 \mathrm{~m}, 5.5 \mathrm{~m}$. Current velocity is $1.0 \mathrm{~m} / \mathrm{s}$ water depth $15 \mathrm{~m}$.

a tidal flow velocity of $0.5 \mathrm{~m} / \mathrm{s}$ and $15 \mathrm{~m}$ water depth the migration is between $2 \mathrm{~m} / \mathrm{y}$ (the smallest surface waves) and $17 \mathrm{~m} / \mathrm{y}$ for the largest surface waves. For deeper water this is reduced to $0-6 \mathrm{~m} / \mathrm{y}$. An increasing tidal current increases the migration due to surface waves.

If the tidal current is no longer purely symmetric, i.e. a residual flow is included, the effect of surface waves changes. The effect of an asymmetric tidal current, which often exists in reality, is firstly that sand waves migrate without the occurrence of surface waves (in the order of $1-10 \mathrm{~m} / \mathrm{y}$ ). Secondly, the sand waves are lowered and become asymmetric (see also Chapter 2). We carried out the same simulations now including an additional residual current. The strength of the residual current is $10 \%$ of the M2-velocity, and the residual current is directed in the same direction as the surface waves. Figure 3.6 gives an overview of the results for the sand wave height. For high flow velocities the sand wave height stays around the same value for larger surface waves, while, for the lower flow velocities, the sand wave height decreases further down to $60 \%$ of its height.

In the low velocity case with deep water the sand wave height decreases again further with increasing surface waves (-58\%). In the high velocity case the total height increases $(+9 \%)$ due to the deepening of the trough $(+57 \%)$. The sand wave crest however is lowered $(-22 \%)$. Though not shown, we note that the shape still changes to a slightly broader crest and smaller trough when surface waves are increased. Migration increases again when surface waves are 


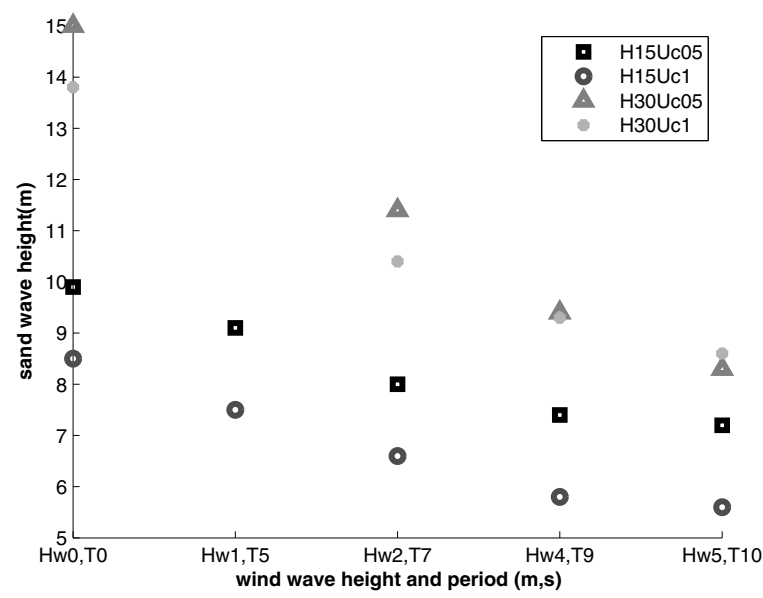

Figure 3.5: Sand wave heights for various combinations of surface waves, water depth and current velocity, after 75 year of simulation. Over the x-axis the surface wave height and period increase. The different symbols indicate different current-water depth combinations, e.g. H15Uc05 means a water depth of $15 \mathrm{~m}$ and a maximum depth averaged current of $0.5 \mathrm{~m} / \mathrm{s}$. The surface waves are in all cases continuous.

included, up to maxima around 2-6m/week $(100-300 \mathrm{~m} / \mathrm{y})$ for the largest surface waves. An overview is given in Figure 3.7. Note that this applies to the case where both the surface waves and the residual current are continuously present and directed perpendicular to the sand wave, causing maximum migration.

\subsubsection{Storm Periods}

In Section 3.3.1 the surface waves are continuously present. The final shapes for higher surface waves should therefore not be interpreted as realistic end results after a storm, but more as the shape where the sand wave tends to if a storm occurs. Also, the migration rates only hold during constant wave conditions, which will decrease the average migration over a year. To investigate the effect of storm periods, the model simulated three scenario's: wind activity for 5 weeks per year $(\sim 10 \%$ exceedance), 1 week per year $(\sim 1 \%)$ and a 1 week extreme storm only once in 25 years $(\sim 0.1 \%$ exceedance) for their accompanying surface waves characteristics.

Figure 3.8 shows the effect of 25 years of different surface wave climates on the sand waves, for a water depth of $15 \mathrm{~m}$ and a tidal velocity of $0.5 \mathrm{~m} / \mathrm{s}$. As expected, the sand waves are lowered less when surface waves only occur during restricted periods. For the shown case, the sand wave lowering is between $2 \%$ and $4 \%$ depending on the surface waves. For the higher velocity case this is $2 \%$ to $6 \%$.

A striking difference with Section 3.3.1 is that the smaller surface waves lower the sand wave crests more than the larger surface waves (Figure 3.8). 


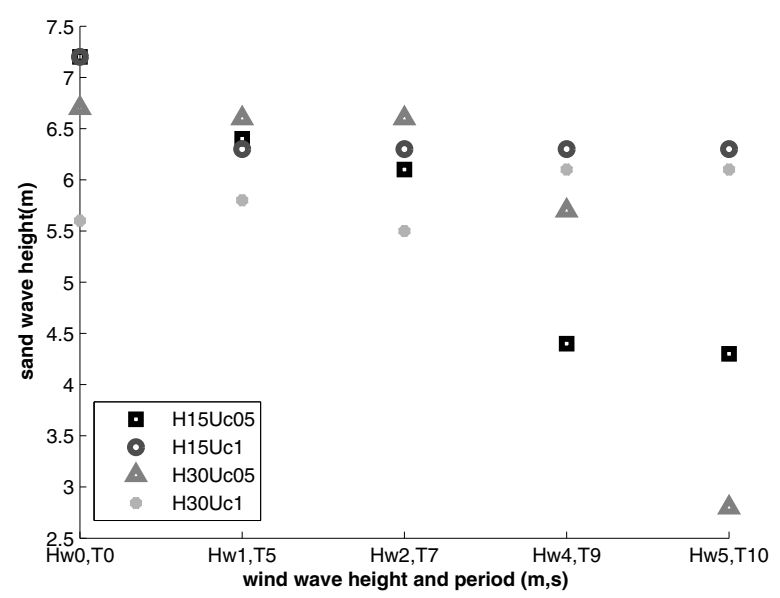

Figure 3.6: Sand wave heights for various combinations of surface waves, water depth and current velocity, after $75 \mathrm{y}$ of simulation. Over the $\mathrm{x}$-axis the surface waves increase. The different symbols indicate different current-water depth combinations, comparable to Figure 3.5. For these simulations a residual current is included.

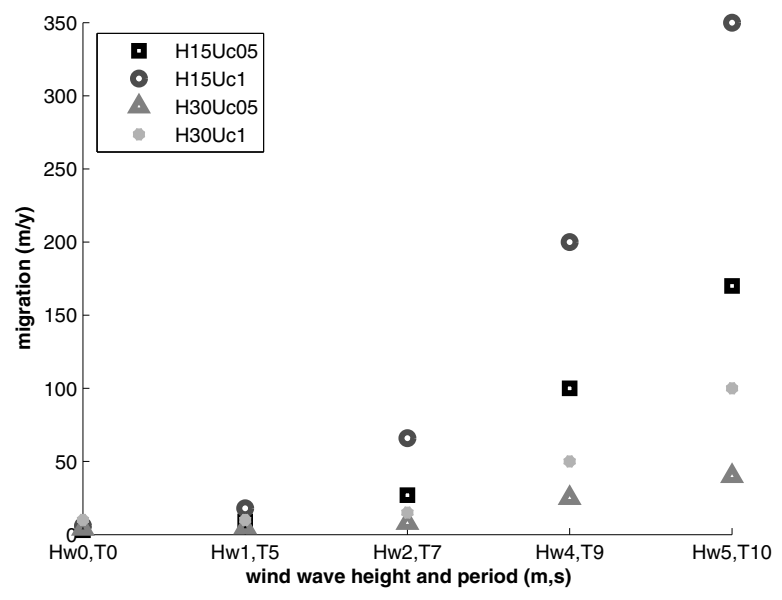

Figure 3.7: Sand wave migration for various combinations of surface waves, water depth and current velocity. Over the x-axis the surface waves increase. The different symbols indicate different current-water depth combinations, e.g. H15Uc05 means a water depth of $15 \mathrm{~m}$ and a maximum depth averaged current of $0.5 \mathrm{~m} / \mathrm{s}$ (of which $10 \%$ is a residual current). The surface waves are in all cases continuous. 

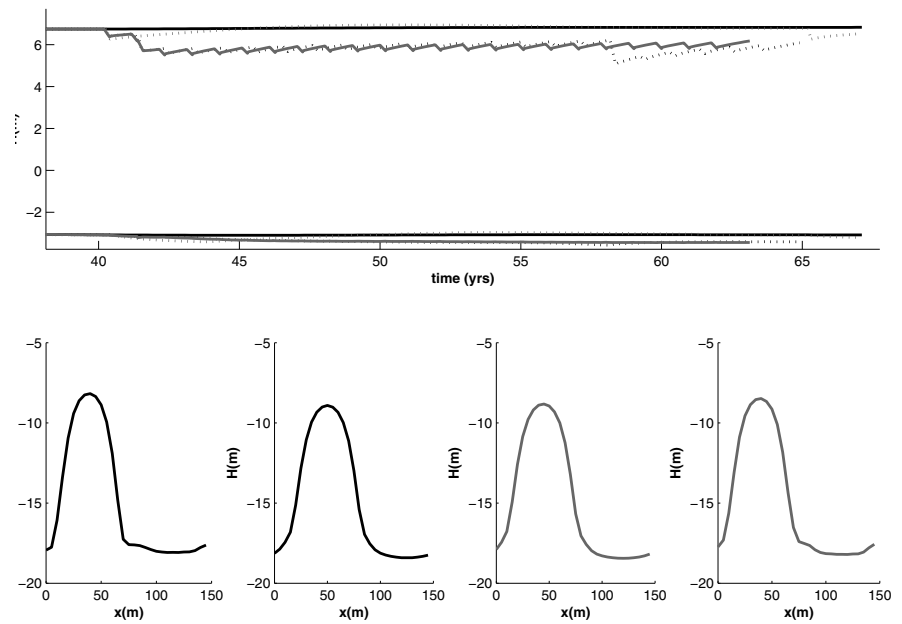

Figure 3.8: Sand wave growth under approximately 25 years of surface waves. The bottom frame in an enlargement of the crestline in the top figure. The different lines show results under different wave height $(\mathrm{m})$ and wave period $(\mathrm{s})$; no waves (solid black), $2.4 \mathrm{~m}$ and $7.0 \mathrm{~s}$ (dashed black), $4.2 \mathrm{~m}$ and $8.9 \mathrm{~s}$ (solid grey), $5.5 \mathrm{~m}$ and $10.7 \mathrm{~s}$ (dashed grey). Current is $0.5 \mathrm{~m} / \mathrm{s}$ water depth $15 \mathrm{~m}$.

Though the extreme storm period itself lowers the sand waves significantly, the time between these major storms is so long that the sand waves return to its 'no surface wave' shape. Most likely, even less effect will occur under the stronger surface waves, as normally they occur for less than a week per a year.

For smaller surface waves with an exceedance percentage of $10 \%-50 \%$, the effect on sand wave height is larger, as they occur more frequently over time. Though the sand waves grow between the storm events, they do not reach the 'no surface wave' height but tend towards an equilibrium between the 'no surface waves' and 'continual surface wave' situation. The more often the surface waves occur, the larger is the effect on the sand wave height.

In these cases there was hardly any migration. Migration occurred with surface waves of $2 \mathrm{~m}$ and $5 \mathrm{~s}$ and $4 \mathrm{~m}$ and $9 \mathrm{~s}$ only. In these conditions the migration was under $2 \mathrm{~m} / \mathrm{y}$.

\subsubsection{Comparison With Field Data}

In Table 3.3 some measured sand wave data are shown from Terwindt (1971); Knaapen (2005) and data described by Besio et al. (2004, 2006) (data provided by Snamprogetti S.p.A.). In general we can say that both the predicted sand wave length and height compares well with the observations. According to the sand wave length there is a slight underprediction while the height is slightly overpredicted. This last is improved by the inclusion of surface waves, especially 
Table 3.3: Characteristics of measured sand waves in the North Sea. For further details we refer to Terwindt (1971); Knaapen (2005); Besio et al. (2006). Note that in Besio et al. (2006) no mean sand wave height is mentioned. For comparison the ranges found in the model simulations in this chapter are given.

\begin{tabular}{lcc}
\hline Source & $\begin{array}{c}\text { sand wave length } \\
\text { min-mean-max }[\mathrm{m}]\end{array}$ & $\begin{array}{c}\text { sand wave height } \\
\text { min-mean-max }[\mathrm{m}]\end{array}$ \\
\hline Terwindt 1971 & $125-314-1250$ & $2.9-6.8-9.1$ \\
Knaapen 2005 & $111-235-340$ & $0.7-2.0-3.4$ \\
Besio 2006 (Site 1) & $200-285-370$ & $3.5-5.5$ \\
Besio 2006 (Site 2) & $165-210-255$ & $2-6$ \\
Model & $120--250$ & $3-15$ \\
\hline
\end{tabular}

Table 3.4: surface wave climate during one year of simulation. Once in 25 years the large storm week is increased to the value between brackets.

\begin{tabular}{lcc}
\hline weeks & $\begin{array}{c}\text { surface wave } \\
\text { height }[\mathrm{m}]\end{array}$ & $\begin{array}{c}\text { surface wave } \\
\text { period }[\mathrm{s}]\end{array}$ \\
\hline $1-14$ & 1.0 & 5.3 \\
$15-16$ & 2.4 & 7.0 \\
17 & $4.2(5.5)$ & $8.9(10.7)$ \\
$18-19$ & 2.4 & 7.0 \\
$20-26$ & 1.0 & 5.3 \\
$27-52$ & 0.0 & 0.0 \\
\hline
\end{tabular}

in shallow water.

For a more in depth comparison, we compare our model results with field data also used by Besio et al. $(2004,2006)$, of two sand wave fields in the North Sea (see Table 3.3). For these locations the required mean parameter values are known, namely the water depth, flow velocity and grain size which are respectively $40 \mathrm{~m}, 0.41 \mathrm{~m} / \mathrm{s}$ and $250 \mu \mathrm{m}$ for Site 1 and $20 \mathrm{~m}, 0.43 \mathrm{~m} / \mathrm{s}$ and $600 \mu \mathrm{m}$ for Site 2. On top of the given oscillating flow on Site 2 also a residual current of $0.02 \mathrm{~m} / \mathrm{s}$ is imposed to reproduce the local tidal conditions.

To compare the simulations (with and without surface waves) with the field data we used an average surface wave year, including the surface waves with their probability of exceedance. The year is divided into different wave conditions, see Table 3.4. Although very schematized, the results give an indication of the combined surface wave influence. Obviously, another division over the year can result in a slightly different outcome.

The results are shown in Table 3.5. We see that the sand wave length is predicted in the lower range of the measured values, while the sand wave height is slightly higher in the original model. If a surface wave regime is included, the sand waves are lowered down to observed heights. Due to model fluctuations the accuracy in the sand wave height is $\pm 1.5 \mathrm{~m}$. 
Table 3.5: Modelled and measured sand wave characteristics. The sand wave length is maintained on the FGM without waves (see Section 3.1). The modelled sand wave height is given including and excluding a surface wave climate. For Site 2 the waves were either collinear or opposite to the residual currents, the last one is put between brackets. Observed migration rates are taken from Besio et al. (2004) (where data was provided by Snamprogetti S.p.A.), where per location two transects were used to find the migration speed.

\begin{tabular}{lccc}
\hline characteristic & measured & $\begin{array}{c}\text { modelled } \\
\text { no waves }\end{array}$ & $\begin{array}{c}\text { modelled } \\
\text { waves }\end{array}$ \\
\hline sand wave length [m] Site 1 & $285 \pm 85$ & 200 & 200 \\
sand wave length [m] Site 2 & $210 \pm 45$ & 150 & 150 \\
sand wave height [m] Site 1 & $3.5-5.5$ & 5.5 & 5 \\
sand wave height [m] Site 2 & $2-6$ & 8 & $6(6)$ \\
migration [m/y] Site 1 & $3.5 \pm 7.1$ & 0 & 7 \\
migration [m/y] Site 2 & $8.8 \pm 11.4$ & & \\
& $4.4 \pm 7.0$ & 5 & $10(0)$ \\
& $6.0 \pm 5.8$ & & \\
\hline
\end{tabular}

The migration rate, including surface waves, for Site 1 compares well with the observed migration, while the migration for Site 2 strongly depends on the wave direction. If the waves in the model are collinear with the residual current the migration rate is around $10-20 \mathrm{~m} / \mathrm{y}$, this reduces to no migration at all if the waves are opposing the residual current. In that case the sand wave height decreases to $6.2 \mathrm{~m}$. As in reality waves will come from different angles, the results shows the maximum and minimum migration effect that waves can have. The shape of the sand wave tends again to a flatter crest and a smaller trough when surface waves are included. In the observations this is the other way around, the crests seem to be smaller than the troughs, with only a few exceptions (Figures 4 and 5 in Besio et al., 2004).

\subsection{Discussion}

\subsubsection{Physical Interpretation}

Section 3.3 clearly shows that surface waves are able to affect both the sand wave morphology and dynamics. Overall, surface waves can lower the sand waves with a few metres to on average $20 \%$ of the sand wave height. Besides, due to surface waves, sand waves migrate several metres per year up to tens (in few cases hundreds) metres per year, when combined with an asymmetric current in the same direction. The sand wave shape slightly changes to a larger flattening crest and a smaller trough.

The effect of surface waves depends on its own characteristics (wave height, period and duration). Larger surface waves themselves have a stronger effect on the sand wave height, however, due to their low frequency in time, their effect is relatively small. If the wave probability of occurrence is taken into account, 
we see that sand waves are most affected by the small, frequently occurring surface waves. Even though an individual large storm can decrease the sand wave height with a few decimetres, this effect diminishes within a few years to a decade. For the smaller waves the effect of an individual storm is smaller but due to their frequency the sand wave has no time to recover and will lower further in the next event.

Indeed, including the effects of a possible climate change, i.e. $10 \%$ more heavy storms, shows that the sand waves are hardly affected by this increase. Firstly, the heavy storms do not occur that much more time, i.e. once in the $22.5 \mathrm{y}$ instead of once in $25 \mathrm{y}$. This means the sand wave still has enough time to recover from the storm effect and grow back to the no wave equilibrium height. Secondly, in most cases it seems like the final equilibrium sand wave without waves only needs a small disturbance (surface waves) to change to a new equilibrium, after which extra disturbances have less effect.

Besides the surface wave characteristics, the physical environment also influences the effects that surface waves can have.

Decreasing the water depth increases the surface wave effect significantly (Figures 3.3-3.5). This can be understood as in deep water smaller waves are less likely to reach the bed than in shallow water, leading to smaller changes in the sand wave shape. The fact that in most cases the crest lowers significantly, while the depth of the trough remains more or less unchanged, agrees with this idea. In those cases, the surface waves only reach the crests and not the troughs of the sand waves. For increasing surface waves in deep water, the surface waves reach a bigger part of the bed, leading to an increased lowering of the sand waves. In shallower water small waves already reach the total bed, lowering the sand waves significantly. If the surface wave height and period increase, the bed is changed less quickly, as already the whole bed is influenced by small waves.

A lowering of the flow velocity increased the effect of surface waves in most cases. The sand waves were lowered more for increased surface waves (Figures 3.5 and 3.6). In shallow water cases this change was larger than in deep water. Two processes act here in different directions. On the one hand, decreasing the current increases the relative effect of the surface waves. On the other hand, larger currents increase the difference in wave height and period within a tidal cycle, when the waves are opposing and in line with the currents. The final effect depends on the relative strength of the different processes (e.g. the difference in stirring within the tidal cycle due to variation in the wave height and period). For shallow water the first process is dominant, while in deeper water both processes balance.

Not only the sand wave height is changed by the surface waves, the sand wave shape changes when surface waves are included. The crests flatten and broaden and the troughs become smaller. Due to the enhanced stirring on the sand wave crests, where the surface waves reach the bed the easiest, the height diminishes. The transported sediment redistributes over the slopes starting close to the crest (broadening the crest) and further down (leaving less space for the trough). As in the model simulation the system is closed, no sediment disappears and the sand wave length is constant. Therefore, the possible non-linear effects on the 
sand wave length and with that the trough crest ratio are not included.

Introducing an asymmetric tidal current changes the effect of surface waves. The residual current already alters the flow, such that the initial small amplitude bed disturbance grows to a lower equilibrium sand wave height in comparison to a symmetric tidal current case. Adding surface waves to such an asymmetric current situation lowers the sand wave height further. This effect depends largely on the flow velocity. For larger tidal currents the effect of surface waves is roughly constant and small for the various surface wave climates, decreasing the sand waves only a little more. For smaller tidal currents, the small surface waves lower the sand waves gradually, but larger surface waves decrease the sand wave height more extreme.

Besides morphological changes, the surface waves trigger the sand wave dynamics. In combination with the symmetric tidal current, the wave characteristics are changed depending on whether they propagate with or against the currents. The transport in the two directions is therefore different as there is more or less sediment stirred by the surface waves. Therefore sand wave migration increases with increasing surface wave heights and periods. In general this effect increases with decreasing water depth and increasing tidal current velocities. A residual current causes the sand waves to migrate without surface waves. But when surface waves occur together with an asymmetric M2-current, the migration is increased by their interaction. Due to the residual current the difference in tidal flow between ebb and flood periods is increased. With that, the surface wave characteristics are more different between ebb and flood periods leading to more migration, up to roughly 8 times the migration without the residual current (in case of a constant wave climate in the same direction as the residual current).

One should note that in these cases the surface waves propagate in the same direction as the residual currents and perpendicular to the crests of the sand waves. The results therefore show a maximum migration. In reality both the (residual) tidal current and the surface waves will be under a different angle, causing a slower sand wave migration. Model runs with opposing surface waves and residual current show indeed a strongly reduced migration rate. Simulations for Site 2 show that waves that are opposing the residual current can damp the migration rate. Other runs show that depending on the strength of both processes migration can be in either direction, with the waves or with the residual current. Besides, the sand wave height is strongly affected by the combination, where opposing forces significantly lower the sand wave height. Incoming waves from different directions can explain the fact that observed sand wave migration is not always perpendicular to the sand wave crest alignment or in line with the tidal current. This could be another explanation for the observed migration in opposite directions than the M4 tide, described in other model studies (e.g. Besio et al., 2004).

The migration caused by surface waves nearly disappears when the waves only occur part of the year. Studying this in more detail we see that the surface waves disturb the sand wave shape for a while but due to the periods without waves the sand waves have time to recover. Though their height might not 
totally recover, their shape does, which nearly stops the migration. When a residual current is included, the sand wave migration remains rapid and the shape stays asymmetric.

When comparing with observations we find that the model, without surface waves, predicts the sand wave length correct in the same range as the observed sand wave length $(\sim 200 \mathrm{~m})$, while the sand wave height is overpredicted. When a surface wave regime is included, covering all the occurring surface waves in a year round climate with a calm and a rough season, the sand wave height is lowered to realistic values. This shows that the surface waves can be an important factor in sand wave morphodynamics.

Other observations of the North Sea (McCave, 1971; Terwindt, 1971; Wilkens, 1997) show that depending on the region sand wave heights differ from around one meter up to more than 7-9 meters. Recently de Koning (2007) investigated the stochastical characteristics of sand wave patches in the North Sea. Together with the mean sand wave heights he also investigated the maximum sand wave height (i.e. where $5 \%$ or $1 \%$ of the sand waves is larger), which ranged up to 12.8 $(5 \%)$ and $13.8 \mathrm{~m}(1 \%)$. These values are close to the modelled sand wave heights excluding surface waves. It seems reasonable to assume that sand waves are lowered further due to physical processes that are not yet included in the model, such as suspended sediment or variation in current velocity (e.g. spring neap variation). Model results in this chapter show that surface waves are likely to cause part of this lowering, due to their disturbance of the equilibrium between the sand wave and the flow.

\subsubsection{Model Simplifications}

One should remember that the model is a strong simplification of reality. We keep the model as simple as possible, while retaining the essential physics. Our main goal is to gain understanding in the influence of different processes. In the following we verify and discuss some of the used model simplifications.

In case of strong currents, in principle, it is possible that the surface waves are blocked or even swept back by the currents. Though the used surface wave model is unable to simulate this non-linear current-wave interaction, in cases where this would occur, i.e. strong currents and small surface waves, the strong current most likely overrules the effect of the relatively small surface waves on the sand waves. With the used surface waves and currents, no problems were encountered in the presented simulations (i.e. the model was always able to find the surface wave characteristics). Still in the simulations the sand waves grow larger than in reality up to heights were surface waves are likely to break due to shallowing water. This effect, which most likely lowers the sand wave crests further, is not included in this study.

Transport of sediment only occurs when the bed shear stress exceeds a certain critical value. This critical value is neglected in the simulations, resulting in a larger sediment transport rate than occurs in reality. Also, the possible non-linear effect of the critical bed shear stress is neglected. Estimates in other studies (Passchier and Kleinhans, 2005; Van Dijk and Kleinhans, 2005) show 
that the critical shear stress is important in offshore cases, preventing sediment transport during parts of the tidal current. As the critical shear stress suppresses the sediment transport during lower flow velocities, we can assume, investigating the results, that in shallow water the sand waves will become higher, and in deeper water lower. Besio et al. (2003b) argues that excluding the critical shear stress results in an overestimation of the sand wave length. Physically, during higher flow velocities the differences between the sand wave crest and trough are larger and sediment will be transported away from the crest more than towards it as the crest experiences higher flow velocities. A decrease in sand wave height seems most likely. Clearly, the critical shear stress also slows down the growth rate and shape changes as sediment transport only occurs during a part of the tidal cycle. This could result in gentler sand wave slopes. The same holds for the inclusion of suspended sediment. This will most likely smoothen and lower the sand waves. Future work will investigate these effects in more detail.

The used combination of surface wave and current bed shear stress especially takes into account the stirring effect by the surface waves, resulting in more sediment transport by the currents if waves are included. Another possible approach is to use an equation by Soulsby (1997) (3.11), that combines the two shear stresses, before calculating the sediment transport.

$$
\tau_{m}=\tau_{\text {current }}\left[1+1.2\left(\frac{\tau_{\text {wave }}}{\tau_{\text {current }}+\tau_{\text {wave }}}\right)^{3.2}\right]
$$

Though other studies show good results (e.g. Kleinhans and Grasmeijer, 2006), the SWC shows hardly any effect of surface waves when this equation is used instead of Equation (3.9). Equation (3.11) deals differently with an increase of either surface wave shear stress or current shear stress. Besides the fact that the total shear stress is always lower for Soulsby's approach, increasing the surface waves has only a minimum effect on the total bed shear stress. This might be caused by the focus on bed shear stress averaged over a surface wave only, excluding the stirring behaviour. Though physically the bed only experiences one total shear stress, we think it is more important to include the different mechanisms involved (i.e. stirring and transport) in which current and surface waves play different roles. It is likely that increasing the surface waves at some point stops increasing the bed load transport as sediment is stirred and brought in suspension. As suspended sediment is not included in the model yet, we assume it is reasonable to increase the modelled bed load transport with increasing surface waves, as a first test of surface wave effects.

In the model we assume the surface waves to be collinear with the currents, and thus perpendicular to the sand waves. In reality the surface waves will come from different angles. In Equation 3.9 the factor before the surface wave term $(\gamma$, see Appendix 3.5) would vary between $1 / 2$ and $3 / 2$ depending on the angle. Though this would affect the results, the general effect will not be changed. The qualitative stirring effect will be the same and with that the transport by currents. The predicted slow migration is caused by the changes in the wave characteristics when the currents are in the same direction or opposing during 
a tidal cycle. This effect will be reduced when the currents and waves are under an angle leading to less migration of the sand wave due to the surface waves.

\subsection{Conclusions}

In this chapter we analysed the influence of surface waves on non-linear fully grown sand waves. The results of the idealized process based sand wave model show that surface waves can significantly influence the sand wave shape and migration. In general surface waves lower the sand wave height and cause migration in the direction of the surface waves. The shape changes to a broader crest, milder slopes and a smaller trough. The quantitative effect depends both on the surface wave characteristics and the sand wave environment.

Though larger surface waves lower the sand waves more, due to their low frequency of occurrence the effect on sand waves is smaller than that of smaller, but more frequent, surface waves. The relative importance of smaller surface waves coincide with observations that indicate that the general surface wave climate is more important than individual large storms.

The effect of surface waves increases for decreasing tidal currents and decreasing water depths. In shallow water small surface waves cause a quick decrease in sand wave height, after which the lowering slows down when the surface waves are increased. In deep water the opposite occurs. On average a lowering of $20 \%$ of the sand wave height and a migration rate of several metres up to tens of metres per year is possible due to surface waves.

Including surface waves improves the sand wave model predictions of sand wave height and migration rate to values in range with observed sand wave values. With this result, we have confidence in the qualitative behaviour that the model predicts. Further investigations will focuss on (1) the inclusion of other processes that can explain the differences between observed and simulated sand waves, such as suspended sediment and a critical bed shear stress and (2) the further investigation of the model assumptions.

\section{Appendix}

\section{Sediment Transport Equation}

The bed load transport without surface waves is included in the model using an extended version of the Meijer Peter-Müller equation (Equation 3.12), following Komarova and Hulscher (2000). For an in depth study of this equation, see Van den Berg (2007). While including surface wave effects in the sediment transport we keep the model as simple as possible, while retaining the essential physics.

$$
q_{b}=\alpha|\tau|^{1 \frac{1}{2}}\left(\frac{\tau}{|\tau|}-\lambda \frac{d h}{d x}\right)
$$

When including surface waves, the total flow velocity can be written as $u_{\text {total }}=u_{\text {current }}+u_{\text {wind }} \sin \sigma t$. For simplicity, we exclude the surface wave 
direction, and assume the surface waves to be in the same direction as the tide. Using a third order dependency on $u_{\text {total }}$ of the sediment transport and averaging over a surface wave we get (with subscript $f$ for current and $w$ for wind):

$$
\begin{gathered}
\left\langle u_{\text {total }}\right\rangle^{3}=\left\langle u_{f}+u_{w} \sin \sigma t\right\rangle^{3} \\
\left\langle u_{\text {total }}\right\rangle^{3}=\left\langle u_{f}^{3}\right\rangle+\left\langle 3 u_{f} u_{w}^{2} \sin ^{2} \sigma t\right\rangle \\
\left\langle u_{\text {total }}\right\rangle^{3}=u_{f}\left(u_{f}^{2}+\frac{3}{2} u_{w}^{2}\right)
\end{gathered}
$$

This is valid as long as we apply linear wave theory, i.e. there is no deformation of the surface waves. Also $\tau_{c r}$ is neglected. If $\tau_{c r}$ is included, the averaging over the surface waves should be done in a later stage, i.e. in the sediment transport equation to include the non-linear effect of $\tau_{c r}$.

Though not shown here, the constant before the term $u_{w}^{2}$ depends on the angle between the surface waves and the current and varies between $\frac{1}{2}$ and $\frac{3}{2}$. We define $\gamma$ as a dimensionless parameter that accounts for this and take its initial value as 1 for simplicity.

Knowing that $\tau$ is proportional to $u^{2}$ we can now write:

$$
q_{b}=\alpha\left|\tau_{f}\right|^{1 / 2}\left(\left|\tau_{f}\right|+\gamma\left|\tau_{w}\right|\right)\left(\frac{\tau_{f}}{\left|\tau_{f}\right|}-\lambda \frac{d h}{d x}\right)
$$

A similar equation is used by Roos et al. (2004) based on a depth averaged flow instead of bed shear stress. 


\title{
Chapter 4
}

\section{Exploring suspended sediment transport effects on sand waves: a model study}

\begin{abstract}
In this chapter we investigate the effect of suspended sediment on offshore sand waves evolution in a calm weather environment. A deterministic idealized model is used to investigate which environmental conditions influence the occurrence of suspended sediment and what the effects on sand wave morphology and dynamics are. The simulations show that suspended sediment in general (1) shortens and lowers the sand waves by $4-17 \%$ and $1-9 \%$ respectively, (2) increases the growth and migration rate and (3) decreases the crest/trough ratio for the sand wave length and height. The qualitative effect of suspended sediment is robust under variation of the water depth, tidal current and grain size. Decreasing the grain size, increasing the current, or changing it from symmetric to asymmetric, increases the quantitative suspended sediment effects. The simulations show that the used sand wave model is able to predict effects of suspended sediment on sand waves. Although the suspended sediment transport is modest, on the long term it can affect the sand wave evolution and final shape. Further research will extend the presented results to rough weather conditions.
\end{abstract}

\subsection{Introduction}

The sea floor of shallow seas is rarely flat and often dynamic. Various bed forms exist on different scales. One widely occurring bed form type is the sand wave (Fig 4.1), for example observed in the North Sea (Van der Veen et al., 2006), the Bisanseto Sea (Knaapen and Hulscher, 2002) and San Francisco Bay (Barnard et al., 2006). Sand waves occur in water depths of 10-50m, where sand is in good supply. Grain sizes are around $200-400 \mu \mathrm{m}$ and the tidal velocities are typically around $1 \mathrm{~m} / \mathrm{s}$. Due to its characteristics (wavelengths of hundreds of metres, heights up to one third of the water depth and a migration rate of several metres per year), sand waves can influence various human activities that take place in shallow coastal seas. For example, navigation, sand mining and transport through pipelines and cables are all activities that are depending on the sand wave behaviour (Morelissen et al., 2003; Németh, 2003).

In relation to offshore activities, not only the main characteristics of sand waves are important but especially the variation, maximum and minimum, in 


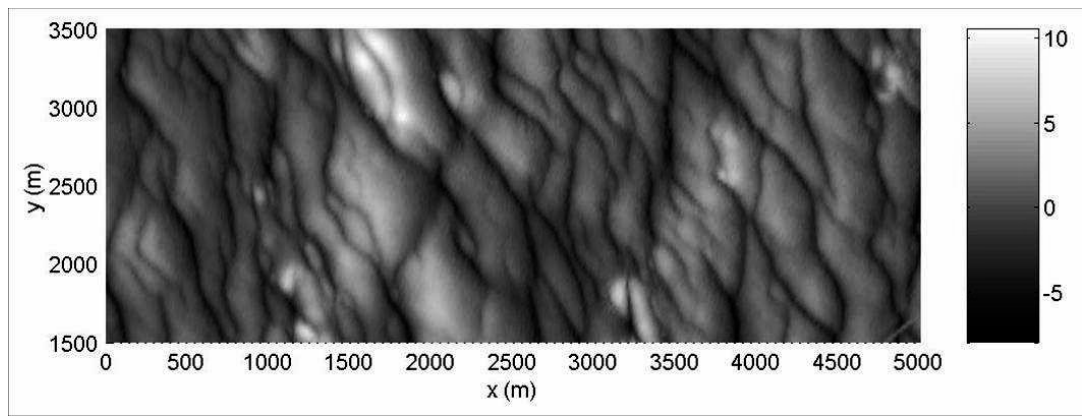

Figure 4.1: Sand waves in the North Sea off the coast of the Netherlands with the position of the seabed in metres compared to the average water depth shown in the colourbar (Data courtesy of North Sea Directorate, The Netherlands).

both space and time.

Variation can be caused by environmental factors, such as tidal flow and sediment characteristics, surface waves and water depth. Variation occurs both in space (in different areas sand waves have different characteristics) and in time (sand waves migrate and grow or decay at certain places).

Field observations indicate that suspended sediment might be of importance for sand wave characteristics. E.g. McCave (1971) investigated sand waves in the Dutch coastal area, together with their physical environment. His observations indicated that sand waves were lower on locations with more suspended sediment transport. Recently, Passchier and Kleinhans (2005) investigated weather influences on compound sand waves and megaripples. Although megaripples were found to be directly influenced by an individual storm, Passchier and Kleinhans (2005) concluded that sand wave morphology is a function of the general wind-wave climate (which is often correlated with suspended sediment transport). This, together with the local setting in which sand waves occur, was reasoned to lead to variation in sand waveshapes. Buijsman and Ridderinkhof (2006) found seasonal dependency of sand wave height and migration in the Marsdiep. In this long term data set (1998-2005), sand waves were on average $30 \%$ higher after calm summer periods than after winter seasons. This variability was greater in locations where, due to finer sediment and stronger tidal currents, suspended sediment was more abundant.

In most idealized model studies of sand waves, suspended sediment transport is not taken into account, as it is expected negligible compared to bed load transport in the water depths where sand waves occur. In the linear sand wave regime (i.e. for the initial sand wave generation where sand wave amplitudes are infinitisimally small) Blondeaux and Vittori (2005a) found that under normal conditions and a flat bed, suspended sediment transport could be $30 \%$ of the bed load transport. Blondeaux and Vittori (2005a,b) used a linear model in three dimensions and included processes like wind waves, suspended sediment and a simple algebraic eddy viscosity (instead of a constant eddy viscosity). 
Blondeaux and Vittori (2005b) tested and used the model in offshore cases with trenches and sand pits which in some cases triggered large scale bedforms. However, as the model is linear, the predictions are all in the initial sand wave state, excluding results on e.g. the final sand wave height and shape. The resulting sand wave length and orientation compare reasonably well with two observed sand wave fields, but the investigation of physical processes is kept to a minimum. Again, no results in the non-linear sand wave regime (i.e. on the final sand wave shape and characteristics) can be obtained.

In the non-linear sand wave regime Németh et al. (2006) showed that nonlinear sand waves can be simulated with only bed load transport and an unidirectional steady current. Van den Berg and Van Damme (2006) extended the model simulations to fields of sand waves and showed that variations in a sand wave field can develop from random small bottom disturbances. Sterlini et al. (2009a) investigated the effect of surface waves on sand waves, but excluded suspended sediment.

A different approach, using a complex full process based model, was used by Tonnon et al. (2007). They studied an artificial sand wave with sand wave dimensions and calibrated the model to describe the observed changes over 15 years. They found that suspended sediment transport (or the mechanisms causing suspended sediment transport) causes a damping of the artificial sand wave. Due to the complex modelling they were unable to model on a morphological time scale and therefore don't give information on the formation and final state of natural sand waves.

In all these studies, the effects of suspended sediment on sand wave morphology and dynamics, i.e. the aim of this chapter, have not yet been studied.

As the field studies indicate, the occurrence of suspended sediment depends on other environmental conditions such as flow velocity, grain size and weather conditions. In sand wave circumstances (water depth around $30 \mathrm{~m}$, grain size around $0.3 \mathrm{~mm}$, flow velocity maximum around $1 \mathrm{~m} / \mathrm{s}$ ) suspended sediment transport is expected to be small compared to the bed load transport. In most model studies suspended sediment is therefore neglected.

In this chapter we explore the influence of suspended sediment transport, using an idealized deterministic model after Van den Berg and Van Damme (2006). We aim to model the total sand wave evolution from the formation up to the final stage including suspended sediment transport. Firstly, we will investigate which model equations for suspended sediment are appropriate for our offshore case. Secondly, we will use the extended sand wave model to investigate what effects the inclusion of suspended sediment has on sand wave morphology and dynamics. After that, we examine the different circumstances under which suspended sediment transport significantly influences the sand waves.

In this chapter we will focus on a fair weather case only, so excluding surface wave effects (Chapter 3, or Sterlini et al., 2009a). This enables us to focus purely on the influence of suspended sediment transport before investigating the interactions between suspended sediment and rough weather circumstances in the non-linear sand wave regime. We will start with describing sand waves (section 4.2), after which we explain the used model including suspended sedi- 
ment (section 4.3). A sensitivity analysis is presented for some important model parameters (section 4.4.1) and for the influence of environmental conditions in combination with suspended sediment transport (section 4.4.2). Finally, the results are discussed (section 4.5) and some conclusions are summarized (section 4.6).

\subsection{Sand waves}

\subsubsection{Sand wave theory}

Sand wave formation is explained as self organisation due to interaction between a sandy seabed and a tidal flow. Sand waves occur as free instabilities in this system, i.e. there is no direct relation between the scales related to the forcing (tide) and those related to the morphological feature (sand wave) (Dodd et al., 2003). Sand wave occurrence can be understood only if the feedback mechanism between the forcing and the seabed is taken into account. Hulscher (1996) described this mechanism of self organization for sand waves, where residual vertical vortices play a crucial role. In short, the process is as follows. Starting from a flat bed with an oscillating current, small perturbations of the sea floor cause small perturbations in the flow field and vice versa. The bed can be either stable, which means that all bed perturbations will be damped, or unstable, which means that certain bed perturbations will grow and the sea bed is changed. If perturbations are unstable the flow field is changed such that, averaged over the tidal cycle, small vertical residual circulation cells occur. These cells cause small net transport over a tidal cycle to the crests of the perturbation, thereby causing growth. Depending on the circumstances such as flow velocity and water depth, perturbations with different lengths will show different growth/decay rates. The fastest growing mode is the perturbation which triggers the fastest initial growth. For small amplitude perturbations, growth can be described as linear, though as sand waves grow larger, non-linear effects become important. However, there are several indicators that seem to imply that sand waves are only weakly non-linear: their amplitude is generally smaller than $20 \%$ of the water depth and the predicted fastest growing wave length (growth in height) is close to the observed wave length. Assuming weak non-linearity, the initially dominating wavelength will be close to the one dominating in the non-linear regime. Subsequently, it is assumed that the fastest growing mode provides the dominant sand wavelength, which is indeed found to be close to the dominating one in reality for weakly non-linear systems (Dodd et al., 2003).

\subsubsection{Sand wave characteristics}

Describing sand waves, different characteristics can be used. Describing sand waves as idealized sinusoidal waves, the wavelength and amplitude are the main characteristics (figure 4.2a). However, sand waves in nature often show cresttrough asymmetry: a sharper higher crest and a lower longer trough (figure $4.2 \mathrm{~b})$. This results in a difference between the crest and trough for both the amplitude and the length. This can be quantified by defining the crest/trough 

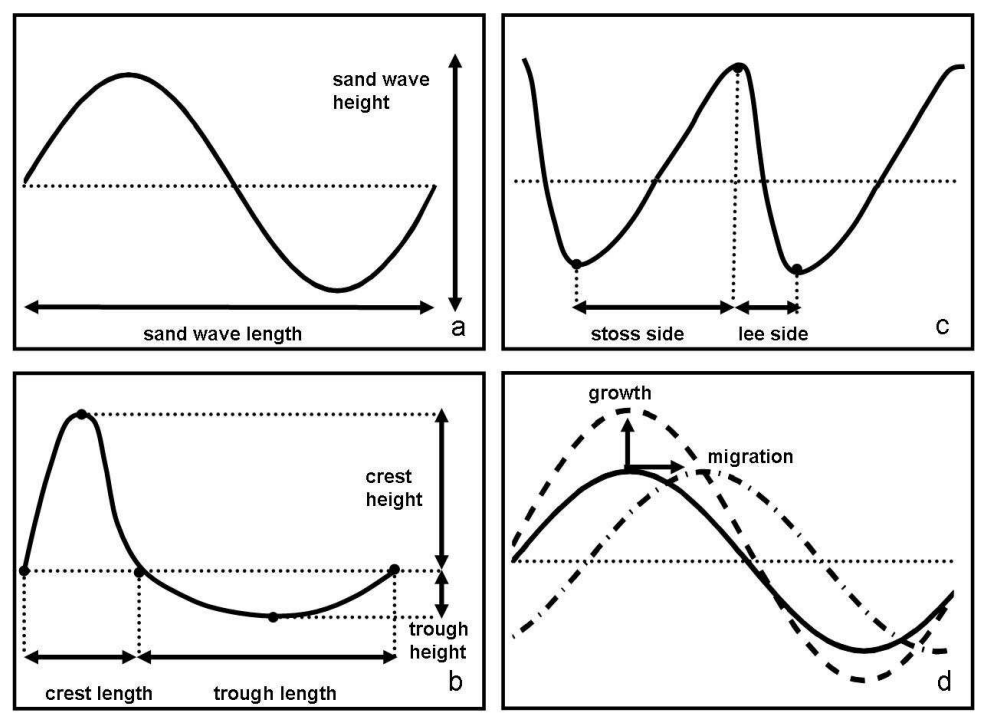

Figure 4.2: Sand wave characteristics, a: ideal sinusoidal sand wave, b: crest-trough asymmetry: sharp crest shallow trough, c: lee-stoss asymmetry: steeper lee side d: growth and migration

ratio (respectively crest over trough height and crest over trough length). For the height ratio a value larger than one then indicates that the distance from mean level to the crest is larger than the distance to the trough. For the length ratio a value larger than one indicates that the crest is wider than the trough. For sand waves the height ratio is typically larger than one and the length ratio is typically smaller than one. Furthermore, lee-stoss asymmetry can occur, for example due to a residual current (figure 4.2c), and in time sand waves can grow as well as migrate (figure $4.2 \mathrm{~d}$ ). This results in sand wave fields with highly variable sand waves.

In this chapter we study both the sand wave morphology (length, height and crest-trough asymmetry) and the dynamics (growth and migration). As most simulations are carried out with a symmetric oscillating tidal flow often no migration takes place.

\subsection{Sand wave model}

The Sand Wave Code (SWC) used in this project is based on an idealized model by Németh et al. (2006) and further developed by Van den Berg and Van Damme (2006). It is a two dimensional vertical model, which is developed specifically to describe sand wave evolution from its generation, to its fully grown state. For sand wave fields in the Southern part of the North Sea and near the Golden 
Gate Channel, the SWC has shown good results in describing the wavelength, height, shape characteristics and migration (Van den Berg and Van Damme, 2006; Németh et al., 2007, 2006; Sterlini et al., 2009b, also Chapter 2).

As the model is idealized, a simple geometry, input and boundary conditions are used, to study morphological features at a morphodynamic time scale, i.e decades. Processes are only included when important for the studied object, in this case sand wave evolution. Results are supposed to represent the trends that occur in nature. Goal is to gain understanding in the effect of various processes and to reproduce the overall statistics.

We start simulations by prescribing sinusoidal, small amplitude, bed waves. Using the bathymetry, the tidal flow is calculated. Since the flow changes over a timescale of hours and the morphology over a timescale of years, the bathymetry is assumed to be invariant within a single tidal cycle $(h(x)$ instead of $h(x, t))$. Once the tidal flow is known, the bed changes are calculated over this typical tide, using a sediment transport equation. This is repeated until the bed evolution exceeds a certain value, after which a new tidal flow is calculated. This, in turn, affects the bed and so the process is iterative. In this way, we are able to simulate the morphological time scale accurately, while avoiding long computation times, as the flow calculations are the most time-consuming part.

For small sinusoidal perturbations, with different wavelengths, it is investigated whether the model predicts growth or decay by investigating the growth rate $\omega=\frac{1}{\Delta t} \log \left(\frac{h_{n e w}}{h_{\text {old }}}\right)$. The growth rate $\omega$ is expressed in $s^{-1}, \Delta t$ denotes the time step and $h_{\text {new }}$ and $h_{\text {old }}$ are the sand wave height before and after the time step. If the growth in height corresponding to various wave lengths is known, the wave length that induces the fastest growth in height can be found (fastest growing mode, FGM). The Sand Wave Code then simulates the growth for this wave length from the initial disturbance to the final sand wave shape that is in equilibrium with the flow.

The model consists of the hydrostatic flow equations for 2DV flow (Equations 4.1 and 4.2). In the horizontal direction, periodic boundary conditions are imposed.

$$
\begin{gathered}
\frac{\partial u}{\partial x}+\frac{\partial w}{\partial z}=0 \\
\frac{\partial u}{\partial t}+u \frac{\partial u}{\partial x}+w \frac{\partial w}{\partial z}=-g \frac{\partial \zeta}{\partial x}+\frac{\partial}{\partial z}\left(A_{v} \frac{\partial u}{\partial z}\right)
\end{gathered}
$$

In these equations $x$ and $z$ represent the horizontal and vertical directions and $u$ and $w$ the horizontal and vertical flow velocities. The variable $t$ denotes time, $\zeta$ is the water surface elevation, $g$ is the constant of gravity and $A_{v}$ is the constant eddy viscosity.

The tidal flow is prescribed as a sinusoidal current by means of a forcing $\mathrm{F}$ (equation 4.3). Variation due to spring-neap tide or seasonal changes is not 
included.

$$
F(t)=F_{0}+F_{s} \sin \left(\omega_{f} t\right)+F_{c} \cos \left(\omega_{f} t\right)
$$

Here $\omega_{f}$ is the angular frequency, $1.4 \mathrm{e}-4 \mathrm{~s}-1$, and F0, Fs and Fc are constants depending on the tidal velocity. A boundary condition at the bed $(h)$ disallows flow through the bed (equation 4.4). A partial slip condition compensates for the constant eddy viscosity, which is known to overestimate the eddy viscosity near the bed (equation 4.5). The resistance parameter $S$ denotes the amount of resistance, with $S=0$ indicating no resistance and $S=\infty$ indicating total resistance. At the water surface $(H+\zeta)$, there is no friction and no flow through the surface (equations 4.6 and 4.7 ).

$$
\begin{gathered}
w-u \frac{\partial h}{\partial x}=\left.0\right|_{h(x)} \\
A_{v} \frac{\partial u}{\partial z}=\left.S u\right|_{h(x)} \\
\frac{\partial u}{\partial z}=\left.0\right|_{H+\zeta(x)} \\
w=\frac{\partial \zeta}{\partial t}+\left.u \frac{\partial \zeta}{\partial x}\right|_{H+\zeta(x)}
\end{gathered}
$$

The flow and the sea bed are coupled through the continuity of sediment (equation 4.8). Sediment is transported in two ways: as bed load transport $\left(q_{b}\right)$ and as suspended load transport $\left(q_{s}\right)$, which are modelled separately. Here we use a bed load formulation after Komarova and Hulscher (2000) (equation 4.9).

$$
\begin{gathered}
\frac{\partial h}{\partial t}=-\left(\frac{\partial q_{b}}{\partial x}+\frac{\partial q_{s}}{\partial x}\right) \\
q_{b}=\alpha\left|\tau_{b}\right|^{b}\left[\tau_{b}-\lambda\left|\tau_{b}\right| \frac{\partial h}{\partial x}\right] \\
\tau_{b}=\left.A_{v} \frac{\partial u}{\partial z}\right|_{h(x)}
\end{gathered}
$$

Grain size and porosity are included in the proportionality constant $\alpha, \tau_{b}$ is the shear stress at the bed (equation 4.10), $h$ is the bed elevation with respect to the spatially mean depth $\mathrm{H}$ and the constant $\lambda$ compensates for the effects of slope on the sediment transport and can incorporate a part of the critical shear stress effects (Komarova and Hulscher, 2000; Németh et al., 2002). The initial effect of a critical shear stress is neglected for the bed load transport. Neglecting the 
critical shear stress is expected to increase the transport rate, but, if the current is symmetric, not to effect the qualitative behaviour. For more details, we refer to Van den Berg (2007).

In order to model suspended sediment transport $q_{s}$, we describe the sediment concentration $c$ throughout the water column, i.e. using a 2DV model (equation 4.11).

$$
\frac{\partial c}{\partial t}+u \frac{\partial c}{\partial x}+w \frac{\partial c}{\partial z}=w_{s} \frac{\partial c}{\partial z}+\frac{\partial}{\partial z}\left(\epsilon_{s} \frac{\partial c}{\partial z}\right)+\frac{\partial}{\partial x}\left(\epsilon_{s} \frac{\partial c}{\partial x}\right)
$$

Horizontal diffusion is assumed to be negligible in comparison with the horizontal advection. The vertical flow velocity, $w$, is much smaller than the fall velocity for sediment, $w_{s}$, and can be neglected in this equation, leading to equation (4.12). This means that the sediment is suspended only by diffusion.

$$
\frac{\partial c}{\partial t}+u \frac{\partial c}{\partial x}=w_{s} \frac{\partial c}{\partial z}+\frac{\partial}{\partial z}\left(\epsilon_{s} \frac{\partial c}{\partial z}\right)
$$

As the flow velocity profile is already calculated throughout the vertical, suspended sediment transport $q_{s}$ can be calculated (equation 4.13 ).

$$
q_{s}=\int_{a}^{H} u(z) c(z) d z
$$

The parameter $\epsilon_{s}$ denotes the sediment diffusivity or vertical diffusion, $a$ is a reference level close to bed above which suspended sediment occurs. $D_{50}$ is the mean grain size, in this chapter we include only one grain size in the simulations. The dimensionless grain size is denoted by $D_{*},(s-1)$ is the relative density of sediment in water and $\nu$ is the kinematic viscosity. Equation (4.14) defines the sediment fall velocity, $w_{s}$ derived from Van Rijn (1993).

$$
\begin{array}{r}
w_{s}=\frac{10 \nu}{D_{50}}\left[\left(1+0.01 D_{*}^{3}\right)^{1 / 2}-1\right] \\
D_{*} \equiv\left(\frac{g(s-1)}{\nu^{2}}\right)^{1 / 3} D_{50}
\end{array}
$$

Suspended load is defined as sediment which has been entrained into the flow. By definition, it can only occur above a certain level, i.e. the reference height, above the sea bed. At this reference height, a reference concentration is imposed as a boundary condition. Various reference levels and concentrations exist for rivers, nearshore and laboratory conditions. Those often applied are Van Rijn (1984); Smith and McLean (1977); Garcia and Parker (1991); Zyserman and Fredsoe (1994). For offshore sand waves, the choice of a reference height is more difficult than it is for the shallower (laboratory) test cases. Here, the reference concentration equation according to Van Rijn (1984) (equation 4.16) is used, 
with a reference height of 1 percent of the mean water depth, corresponding with the minimum reference height proposed in Van Rijn (1984) (see also Van Rijn and Walstra (2003)).

$$
\begin{aligned}
c_{a} & =f_{\text {eff }} 0.015 \frac{D_{50}}{0.01 H D_{*}^{0.3}}\left(\frac{|\tau|-\tau_{c r}}{\tau_{c r}}\right)^{1.5} \\
\tau_{c r} & =\left(\rho_{s}-\rho_{w}\right) g D_{50} \theta_{c r} \\
\theta_{c r} & =\frac{0.24}{D_{*}}+0.055\left(1-\exp \left(-0.02 D_{*}\right)\right)
\end{aligned}
$$

The reference concentration at height $a$ above the bed is given by $c_{a}$ and $\tau_{c r}$ is the critical shear stress necessary to move sediment (equation 4.17 and 4.18 after Soulsby (1997)). $f_{\text {eff }}$ is an efficiency coefficient (here $f_{\text {eff }}=1$ ). To complete the set of boundary conditions for sediment concentration, we disallow flux through the water surface.

Numerically a transformation is used that maps the domain with the bed perturbation back to one with a flat bed, such that a rectangular structured grid can be used (Van den Berg, 2007). For the presented model results 30 grid points are used to cover the horizontal distance and 20 grid points to cover the vertical distance. Model tests have shown that this resolution is enough to cover the dynamic sand wave behaviour. Due to the transformation the bed level accuracy is independent of the grid size. The reference height for suspended sediment is always set to $1 \%$ of the mean water depth, $H$, above the bed, independent of the bed topography. Both the gradient and the quantity of suspended sediment are largest close to the bed. Therefore, concentration values are calculated on a grid with a quadratic point distribution on the vertical axis, such that more points are located closer to the bed and fewer points are present higher in the water column. Because the flow is computed on a linear grid, a polynomial reconstruction is used to map the flow solution to the quadratic grid for the concentration.

\subsubsection{Sediment diffusivity model}

Soulsby (1990) listed various profiles for the diffusivity of water, to which sediment diffusivity is highly comparable. Van Rijn (1993) connected these two diffusivities with two terms compensating for the influence of sediment on the flow in case of high sediment load ( $\phi$, omitted in this study) and the difference in diffusion between a fluid 'particle' and a sediment particle (pp 7.53 onwards). He expected the influence of the various profiles of minor importance on the flow velocity, depending also on certain boundary conditions. Differences between the profiles are largest close to the bed. As changes in suspended sediment are largest exactly close to the bed, possibly the diffusivity profiles influences the suspended sediment transport more than the flow velocity. Therefore three different profiles are tested in the simulations. A constant value over depth (equation 4.19), comparable to the fluid diffusivity model, and two depth depending profiles, one linear (equation 4.20) and one parabolic-constant in which 


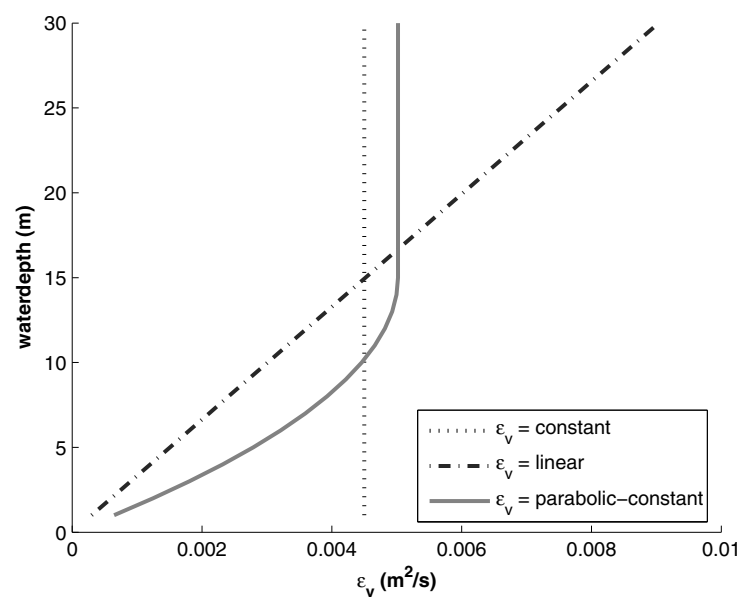

Figure 4.3: Three different sediment diffusivity profiles, corresponding to equations 4.19-4.21.

$\epsilon_{v}$ is parabolically increasing for the lower part of the water column and above that constant over depth (equation 4.21, see also Figure 4.3).

$$
\begin{aligned}
\epsilon_{v 1} & =\alpha A_{v} \\
\epsilon_{v 2} & =\kappa \beta u_{*} z \\
\epsilon_{v 3} & = \begin{cases}\kappa \beta u_{*} z\left(1-\frac{z}{H}\right) & \text { for } z<0.5 H \\
0.25 \kappa \beta u_{*} H & \text { for } z \geq 0.5 H\end{cases}
\end{aligned}
$$

In these equations $\epsilon_{v}$ is the sediment diffusivity, $\alpha$ a constant, $A_{v}$ the eddy viscosity and $\kappa$ the Von Karman constant (0.4). The difference between a water and a sediment particle is described by $\beta$ (4.23), with a maximum value of 2 .

$$
\beta=1+2\left(\frac{w_{s}}{u_{*}}\right)^{2} \text { for } 0.1<\frac{w_{s}}{u_{*}}<1
$$

The bed shear velocity is denoted by $u_{*}, z$ is the vertical coordinate and $H$ the water depth.

\subsection{Model results}

\subsubsection{Model parameters}

To model sand waves, simplifications have to be made. Therefore, the used equations and parameters, already influence the sand wave characteristics before environmental conditions are taken into account (e.g. transport formula and 
Table 4.1: Default parameter values for the reference simulation.

\begin{tabular}{lll|lll}
\hline parameter & value & unit & parameter & value & unit \\
\hline $\bar{u}$ & 0.5 & $\mathrm{~m} / \mathrm{s}$ & $\overline{\epsilon_{v}}$ & 0.0045 & $\mathrm{~m}^{2} / \mathrm{s}$ \\
$H$ & 30 & $\mathrm{~m}$ & $D_{50}$ & 300 & $\mu \mathrm{m}$ \\
$A_{v}$ & 0.03 & $\mathrm{~m}^{2} / \mathrm{s}$ & $w_{s}$ & 0.04 & $\mathrm{~m} / \mathrm{s}$ \\
$S$ & 0.01 & $\mathrm{~m} / \mathrm{s}$ & $a$ & 0.3 & $\mathrm{~m}$ \\
$\alpha$ & 0.3 & - & $\lambda$ & 2.5 & - \\
$\tau_{c r}$ & 0.18 & - & $\omega_{f}$ & $1.4 \mathrm{e}-4$ & $\mathrm{~s}-1$ \\
\hline
\end{tabular}

the bed slope parameter). Therefore, a choice of these equations and their accompanying parameters is of great importance. In this section some crucial parameters will be discussed and established, based on a sensitivity analysis. Table 4.1 shows default values used in the simulations, mostly typical values for the North Sea. We denote the depth averaged mean velocity of the oscillating tidal flow by $\bar{u}, H$ is the mean water depth.

\section{Bed load slope parameter}

Following Németh et al. (2006) and Van den Berg and Van Damme (2006) we use the equation of Komarova and Hulscher (2000) for bed load transport (equation 4.9). Komarova and Hulscher (2000) extended the equation of MeyerPeter and Muller with a slope term to take into account the fact that sediment is transported downhill easier than uphill. The parameter $\lambda$ includes this bed slope effect. A value of 0 means the slope has no influence on the sediment transport and the slope angle can be up to 90 degrees. Increasing $\lambda$ lowers the maximum possible slope (angle of repose). E.g. a $\lambda$ of 1.7 gives a maximum angle of 30 degrees and a $\lambda$ of 2.5 of 22 degrees. $\lambda$ not only affects the maximum slope, but already for milder slopes it results in less uphill and more downhill transport. Because of this effect $\lambda$ can affect the length/height ratio of sand waves and their final height.

Figure 4.4 shows the influence of $\lambda$ on the FGM and the accompanying growth rate. Every line visualizes the growth rate for different wave lengths and one $\lambda$. With $\lambda$ increasing we see that the FGM increases, from $280 \mathrm{~m}$ to $700 \mathrm{~m}$. The maximum growth rate decreases from $1.9 \mathrm{e}-9 \mathrm{~s}^{-1}$ to $4.2 \mathrm{e}-9 \mathrm{~s}^{-1}$, if $\lambda$ increases from 2.0 to 4.0. Increasing $\lambda$ dampens shorter waves, and results in slightly longer sand waves. The change in final height balances between two processes. Firstly an increasing $\lambda$ lowers the angle of repose and thus the final height for a certain wave length. Secondly, increasing $\lambda$ increases the wave length which increases the maximum wave height. Results show that the length/height ratio remains roughly constant.

In this chapter we use $\lambda=2.5$ as default value, following Van den Berg and Van Damme (2006). This results in sand waves with a wave length of $440 \mathrm{~m}$ that grow from $0.1 \mathrm{~m}$ amplitude to their final crest(trough) amplitude of $+13.7 \mathrm{~m}$ $(-8.2 \mathrm{~m})$ in 75 year. 


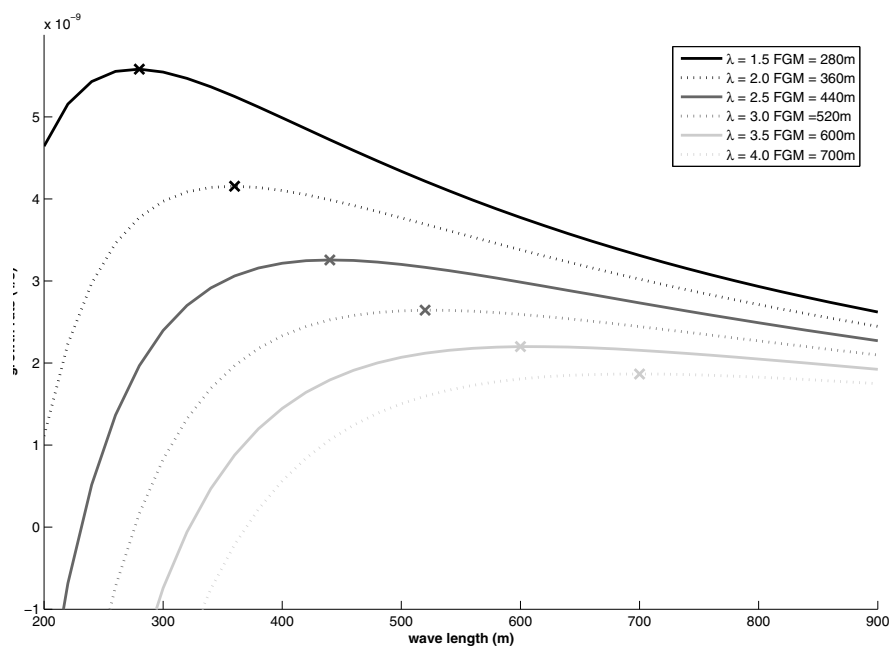

Figure 4.4: Influence of $\lambda$ on the fastest growing mode. The lines indicate the growth rate for different wave lengths for a specific $\lambda$. The crosses on the lines indicate the fastest growing mode.

\section{Sediment diffusivity}

Various profiles exist for the sediment diffusivity. For numerical modelling of suspended sediment transport we aim to select the diffusivity model which describes the transport appropriately, using as simple equations as possible. For the present numerical code we tested three sediment diffusivity models (equations $4.19,4.20$ and 4.21 ). Figure 4.3 shows the profiles with equal mean sediment diffusivity over depth, Figure 4.5 shows the effect of the three profiles on the sand waves. Figure 4.5 shows that the linear and parabolic-constant models hardly differ. The constant sediment diffusivity model differs significantly from the other two models. When the constant value is lowered the result becomes more and more like the other two profiles. This shows that it is not so much the profile but the value at the bed that influences the model results most. This can be understood from the fact that the sediment is not suspended high in the water column but only close to the bed. Therefore, a constant sediment diffusivity profile could be used, but only when the value at the bed would be known. To overcome this arbitrary choice of $\alpha$, we use the linear profile.

\subsubsection{Model sensitivity}

Starting with the model and parameters as described in the previous section, the influence of suspended sediment is investigated, under various conditions. Firstly the reference case, with and without suspended sediment is investigated in detail. After that various conditions are varied to investigate their effect on 

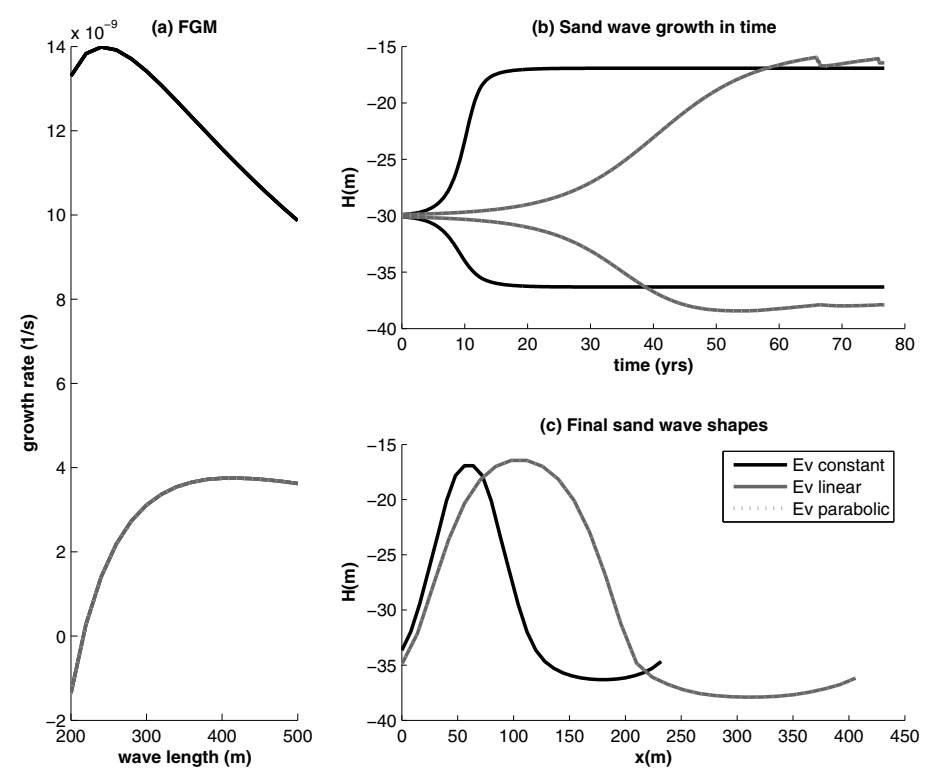

Figure 4.5: Influence of the sediment diffusivity profile on sand waves. (a) shows the initial growth rate for different wave lengths. (b) shows the crest and trough growth for the FGM in time. (c) shows the final sand wave shape, the legend holds for all three figures. Note that for all figures, the results for the linear and the parabolic profile are identically on this scale. 
Table 4.2: Parameters values for various runs. Note that for a water depth of $40 \mathrm{~m}$ the model was unable to find a stable solution when suspended sediment was included. Therefore, a water depth of $39 \mathrm{~m}$ was used in run 4 .

\begin{tabular}{l|lllll}
\hline $\begin{array}{l}\text { run } \\
\text { number }\end{array}$ & $\begin{array}{l}\text { Water } \\
\text { depth }(\mathrm{m})\end{array}$ & $\begin{array}{l}\text { grain } \\
\text { size }(\mu \mathrm{m})\end{array}$ & $\begin{array}{l}\text { flow } \\
\text { velocity }(\mathrm{m} / \mathrm{s})\end{array}$ & $\begin{array}{l}\text { residual } \\
\text { current }(\mathrm{m} / \mathrm{s})\end{array}$ & $\begin{array}{l}\text { suspended } \\
\text { sediment }\end{array}$ \\
\hline 1 & 30 & 300 & 0.5 & 0 & no \\
2 & 30 & 300 & 0.5 & 0 & yes \\
3 & $\mathbf{4 0}$ & 300 & 0.5 & 0 & no \\
4 & $\mathbf{3 9}$ & 300 & 0.5 & 0 & yes \\
5 & $\mathbf{2 0}$ & 300 & 0.5 & 0 & no \\
6 & $\mathbf{2 0}$ & 300 & 0.5 & 0 & yes \\
7 & 30 & $\mathbf{4 0 0}$ & 0.5 & 0 & no \\
8 & 30 & $\mathbf{4 0 0}$ & 0.5 & 0 & yes \\
9 & 30 & $\mathbf{2 0 0}$ & 0.5 & 0 & no \\
10 & 30 & $\mathbf{2 0 0}$ & 0.5 & 0 & yes \\
11 & 30 & 300 & $\mathbf{1 . 0}$ & 0 & no \\
12 & 30 & 300 & $\mathbf{1 . 0}$ & 0 & yes \\
13 & 30 & 300 & $\mathbf{0 . 3}$ & 0 & no \\
14 & 30 & 300 & $\mathbf{0 . 3}$ & 0 & yes \\
15 & 30 & 300 & 0.5 & $\mathbf{0 . 0 5}$ & no \\
16 & 30 & 300 & 0.5 & $\mathbf{0 . 0 5}$ & yes \\
\hline
\end{tabular}

sand waves both directly and indirectly via the suspended sediment. The varied parameters are water depth, grain size, current speed and residual current. In all the simulations we assume fair weather, i.e. we neglect processes due to surface waves. Table 4.2 shows the values of the parameters and Table 4.3 the simulation results (simulation 1 and 2 are the reference case without and with suspended sediment respectively). For all cases, the FGM is found using $20 \mathrm{~m}$ increments.

\section{Reference case}

Figure 4.6 compares the simulations with only bed load, only suspended load and the combination of these two transport types. When only suspended sediment transport is included, the initial growth rates are still positive. However, figure 4.6 shows that the preferred sand wave length is lower than $40 \mathrm{~m}$, i.e. outside our scope of sand waves and the shallow water approximation (which assumes the length scale is -much- larger than the water depth). The growth to the final shape is simulated with a wave length of $100 \mathrm{~m}$. In the simulation with only suspended sediment, the final amplitude explodes after 65y. This is caused by the lack of a slope term for suspended sediment, combined with the preference for small wave lengths. Small disturbances grow therefore up to peaked instabilities. The shape in Figure $4.6 \mathrm{c}$ is just before the simulation fails.

When we compare the bed load case and the combined case, the suspended 
Table 4.3: Model results for various runs.

\begin{tabular}{l|lllll}
\hline $\begin{array}{l}\text { run } \\
\text { number }\end{array}$ & $\begin{array}{l}\text { FGM } \\
(\mathrm{m})\end{array}$ & $\begin{array}{l}\text { finite } \\
\text { crest }(\mathrm{m})\end{array}$ & $\begin{array}{l}\text { amplitude } \\
\text { trough }(\mathrm{m})\end{array}$ & $\begin{array}{l}\text { crest/trough } \\
\text { length }(-)\end{array}$ & $\begin{array}{l}\text { time to finite } \\
\text { amplitude }(\mathrm{yr})\end{array}$ \\
\hline 1 & 440 & +14.3 & -7.7 & 0.66 & 90 \\
2 & 420 & +13.6 & -7.9 & 0.65 & 75 \\
3 & 500 & +15.6 & -10.0 & 0.61 & 120 \\
4 & 400 & +13.1 & -9.5 & 0.80 & 80 \\
5 & 420 & +13.2 & -11.7 & 0.95 & 75 \\
6 & 380 & +13.0 & -11.0 & 0.93 & 75 \\
7 & 440 & +14.3 & -7.7 & 0.66 & 90 \\
8 & 420 & +14.0 & -7.8 & 0.68 & 75 \\
9 & 440 & +14.3 & -7.7 & 0.66 & 90 \\
10 & 400 & +13.9 & -7.5 & 0.66 & 70 \\
11 & 480 & +13.3 & -7.2 & 0.64 & 35 \\
12 & 400 & +13.1 & -6.8 & 0.62 & 25 \\
13 & 440 & +16.5 & -9.6 & 0.73 & 230 \\
14 & 420 & +16.0 & -9.3 & 0.73 & 200 \\
15 & 420 & +11.6 & -7.3 & 0.81 & 75 \\
16 & 360 & +10.5 & -6.9 & 0.80 & 60 \\
\hline
\end{tabular}

sediment effect on the sand waves is subtle. Figure 4.6a shows that including suspended sediment on top of the bed load decreases the FGM, from 440m to $420 \mathrm{~m}$. The growth rate increases with approximately $15 \%$. Figure $4.6 \mathrm{~b}$ visualizes the growth to the final amplitude, which is reached after 60 and 75 years with and without suspended sediment transport respectively. Figure 4.6c shows the finite sand wave forms. The finite form is only slightly changed. Firstly, the final height is smaller due to small changes in both the trough and the crest position. Secondly, the crest-trough asymmetry in length is increased (crest/trough ratio from 0.72 to 0.69 ) due to the steeper slopes, which result in a smaller crest length. The crest-trough asymmetry in height remains roughly the same. The changes can be understood from the preference of suspended sediment transport for smaller sand waves. Though the sediment transport in suspension is roughly 10 times smaller than the bed load transport, it changes the sand waves towards a smaller (shorter and lower) shape. Due to the lack of a slope term the crest slopes can get slightly steeper.

Further in detail, Figure 4.7a,b and c show the sediment transport (upper panels) and the divergence of sediment (middle panels), together with the resulting seabed (lower panel). The different figures show different moments in the sand wave evolution, Figure $4.7 \mathrm{a}$ shows the evolution after 1 year, Figure $4.7 \mathrm{~b}$ after 38 years and $4.7 \mathrm{c}$ after 77 years. For simulation 1 the bed load transport and its gradient are shown (black line). For simulation 2 both the suspended load and the bed load transport are shown (dotted grey line and dashed grey line respectively). Besides also the total transport for simulation 2 is plotted 

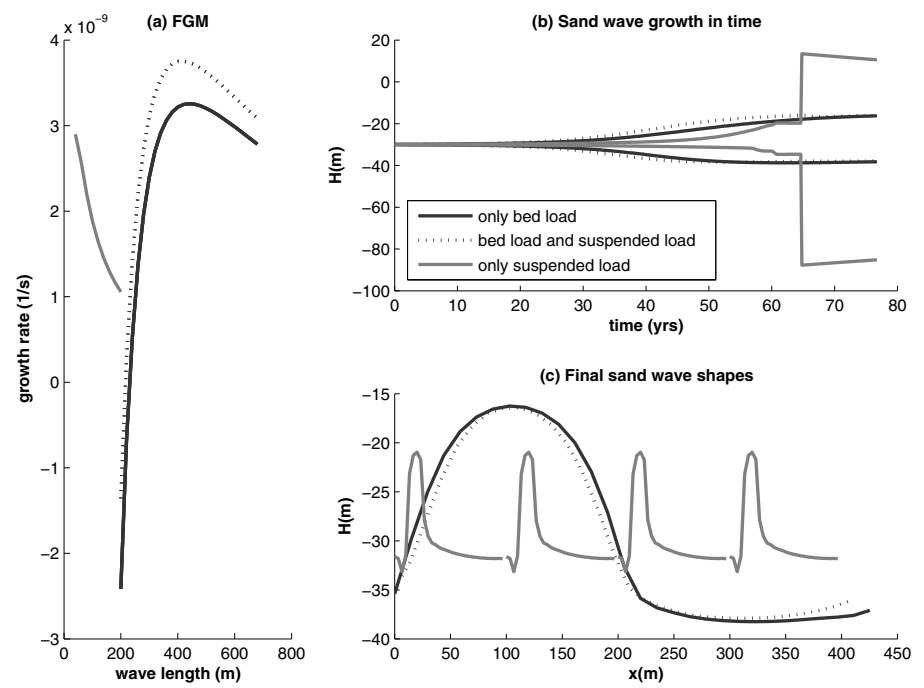

Figure 4.6: Influence of suspended sediment load and bed load on the sand waves. (a) shows the initial growth rate for different wave lengths. (b) shows the crest and trough growth for the FGM in time, and (c) shows the final sand wave shape for the three simulations. The legend holds for all three figures.

(grey line). The shown time steps represent the sand wave just after the growth has started (initial), near its final state and in between these stages. For both simulations the transport gradient initially follows the sand wave shape: positive gradient at the crest (deposition) and a negative gradient at the trough (erosion). When the sand wave grows larger non-linear effects start to change the transport and so the sand wave shape. Stronger gradients occur at the slopes, which become steeper and change position as the crest becomes less wide. Close to the final stage the trough and crest are in equilibrium and only the slopes show transport gradients. They slowly get steeper and gradients get smaller towards the final equilibrium sand wave shape (not shown).

When suspended sediment is included, the overall net transport increases and consequently the growth rate increases. Due to the faster evolution the transport curves in the intermediate state in Figure 4.7 are different as the sand wave shape is already steeper. However, in general the qualitative total transport over the sand wave is in both simulations the same. Quantitatively simulation 2, including suspended sediment load, evolves quicker.

Comparing the suspended load and the bed load over the sand wave in simulation 2 we see they behave rather differently. Firstly, the bed load is approximately ten times larger than the suspended load. Near the final stage they become more in the same order of magnitude. The suspended sediment transport increases at the crests and the slopes as the sand wave grows larger. Near 
the final stage the suspended load transport balances the bed load transport at the crest. In the trough the suspended sediment transport decreases to nearly zero, while the bed load transport remains directed from the trough to the crest.

In summary, including suspended sediment increases the sand wave growth and steepens the slopes. At the crest and trough suspended sediment transport balances the bed load transport after a certain time. At the slopes the transport gradients occur longer in time and the sand wave continues changing its shape at the slopes. Both for the suspended load and the bed load the transport shows steep gradients.

Figure 4.8 (left panels) shows the sediment concentration near the bed and the tidal current velocity at one point in space over a tidal cycle. The right panels show the sediment concentration near the bed over the sand wave at two moments in the tidal cycle. The sediment is mostly entrained in the first $0.5 \mathrm{~m}$ above the bed above which the concentrations are negligible. Maximum values occur during high flow velocities with a maximum of $1.2 \mathrm{e}-5 \mathrm{~m} 3 / \mathrm{m} 3$ (approximately $30 \mathrm{mg} / \mathrm{l}$ ) at $30 \mathrm{~cm}$ above the bed. This reduces quickly to $1 \mathrm{mg} / \mathrm{l}$ at $50 \mathrm{~cm}$ above the bed.

\section{Physical conditions}

Table 4.3 shows that for all runs the FGM varies between $360 \mathrm{~m}$ and $500 \mathrm{~m}$. Suspended sediment shortens the sand wave length in all cases with 4 to $17 \%$. Largest impact of suspended sediment is caused when the flow conditions are higher or asymmetric. The combination of smaller grains and suspended sediment shortens the wave length. As smaller grain sizes are entrained more easily, the percentage of suspended sediment is increased and has more effect on the sand wave morphology. Also in shallower water the effect of suspended sediment increases. Here, the flow velocity at the bed increases (as the depth averaged velocity stays the same) which again increases the sediment sediment and decreases the ratio between $Q_{b}$ and $Q_{s}$. Note that for a larger water depth of $40 \mathrm{~m}$ the model was unable to find a stable solution. Therefore, a water depth of $39 \mathrm{~m}$ was used in run 4.

Besides the suspended sediment effects, also the conditions itself affect the FGM. Both water depth and flow velocity affect the sand wave length significantly (both around 10\%). The grain size only influences the FGM and final height when suspended sediment is included. Suspended sediment lowers the total amplitude in all cases, except for the very low flow conditions (run 13 and 14) where a slight increase is visible. The total decrease is on average $-4 \%$ with a maximum of $-9 \%$ when the flow is asymmetric (run 15 and 16). Both trough and crest amplitude changes, with -6 to $3 \%$ and -16 to $-2 \%$ respectively.

Including suspended sediment increases the crest/trough asymmetry in the sand wave length. Without suspended sediment sand waves are already asymmetric, but suspended sediment transport further increases the difference between crest and trough length. The crest becomes sharper and narrower and the trough longer and (in most cases) shallower. For the sand wave length the crest/trough ratio decreases up to $3 \%$ when suspended sediment is included. 

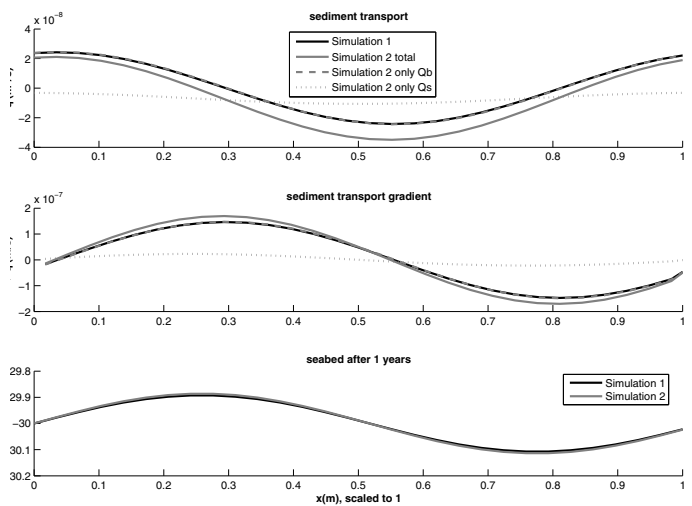

(a)
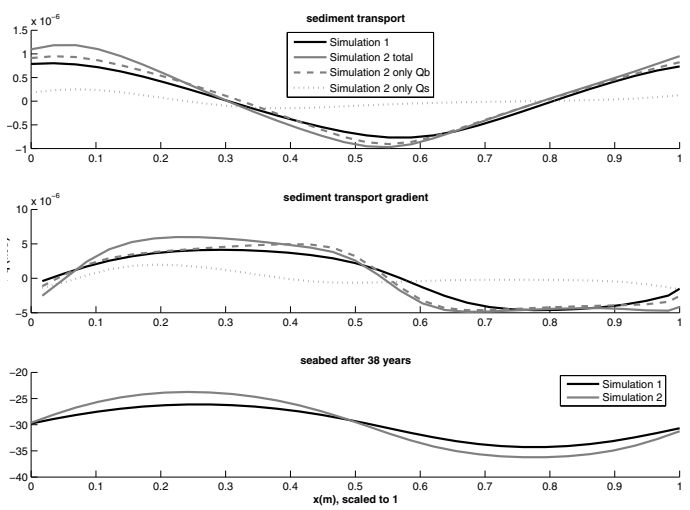

(b)
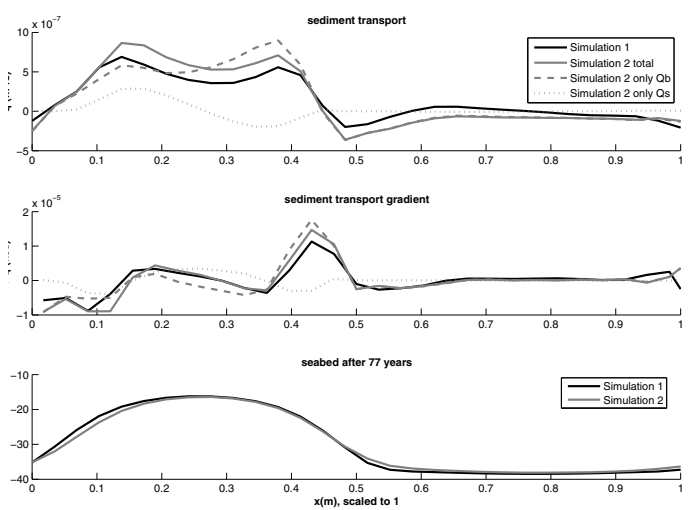

(c)

Figure 4.7: Sediment transport and gradient over the sand wave for 3 stages in the sand wave evolution. The shown values are averaged over a tidal cycle. (a) shows the processes after 1 year of simulation, (b) after 38 years and (c) after 77 years. 

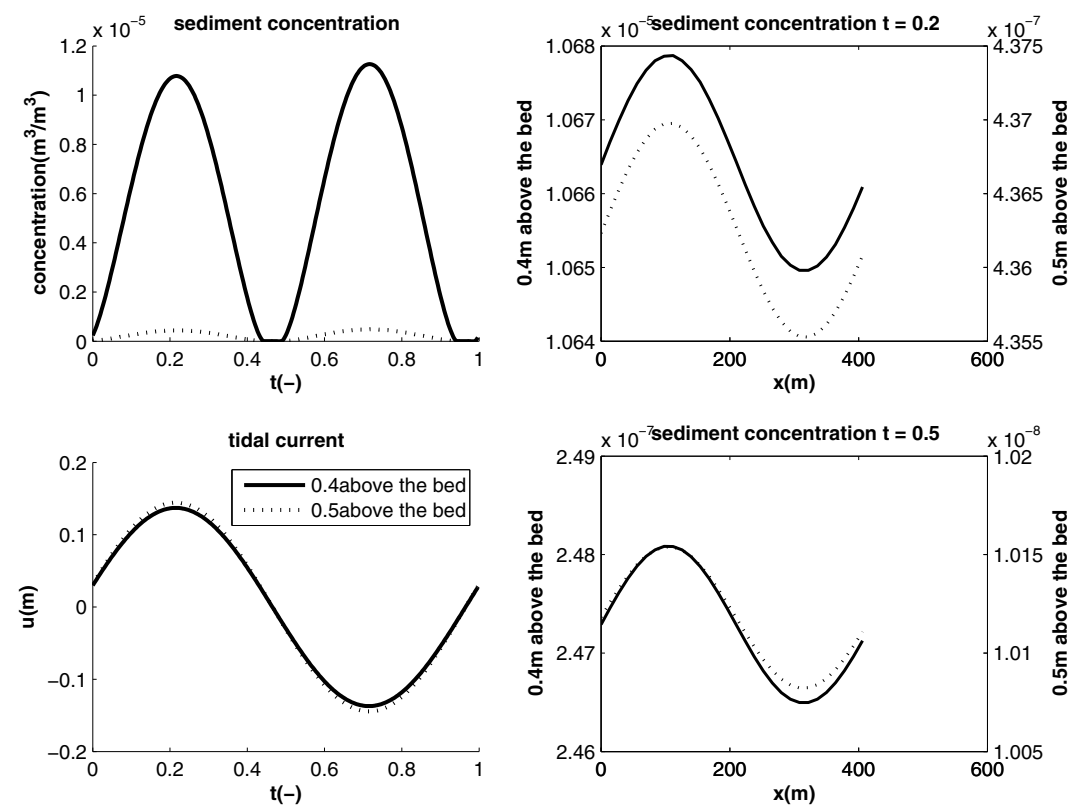

Figure 4.8: Sediment concentrations over a tidal cycle. The upper left panel shows the sediment concentration $\left(\mathrm{m}^{3} / \mathrm{m}^{3}\right)$ at the crest over a tidal cycle (time is scaled from 0 to 1$)$. The tidal flow velocity $(\mathrm{m} / \mathrm{s})$ is shown in the lower left panel. At the right, the sediment concentrations over a tidal sand wave are shown for two moments in the tidal cycle. Note that the sediment concentrations are shown only in the first few decimetres above the bed. Higher in the water column sediment concentrations are negligibly small. 
(a) Small grain size simulation

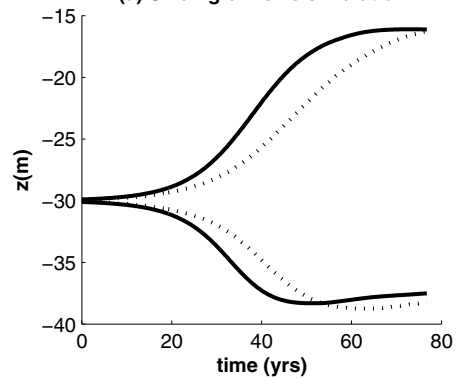

(b) Residual current simulation

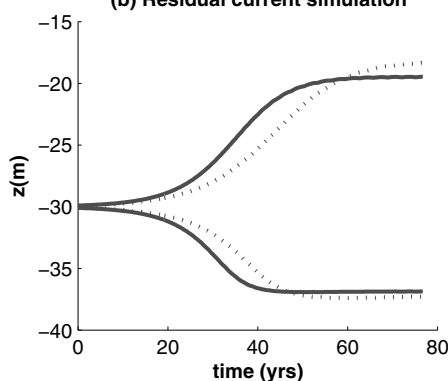

(c) Final sand wave shapes

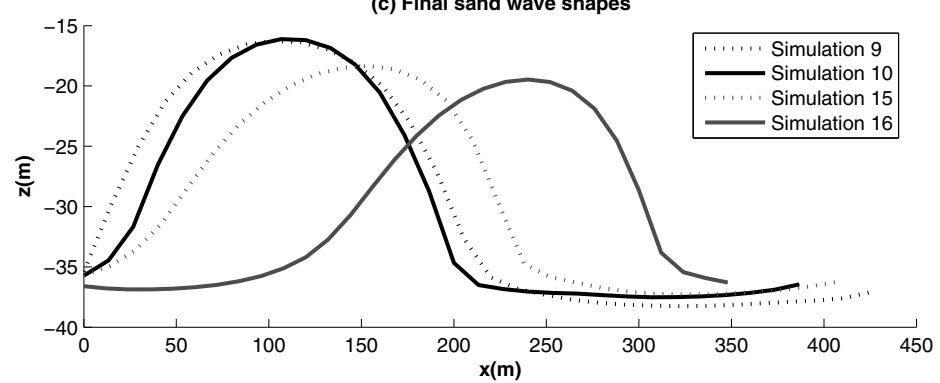

Figure 4.9: Influence of suspended sediment on two cases. (a) and (b) show the growth of the crest and trough in time for the small grain size case and the residual current case respectively. The solid lines are including suspended sediment, the dotted line excluding suspended sediment. (c) shows the final sand wave shape for all the four simulations, line characteristics are equal to (a) and (b).

Without suspended sediment, the crest amplitude is roughly 1.5 to 2 times larger than the trough amplitude. As including suspended sediment reduces both the trough and the crest amplitude, the asymmetry can either increase or decrease (between +5 and $-18 \%$ ).

Figure 4.9 shows two examples of the results, namely the case with smaller grain size (run 9 and 10) and the case including a residual current (run 15 and 16). It shows the reduction of height, which is larger in the residual current case than in the small grain size case. In both cases the crest steepens and the trough gets longer and shallower.

Besides the morphological changes, Figure 4.9 and Table 4.3 also show that suspended sediment increases the growth rate and so shortens the time needed reach the finite amplitude. Growth from the initial amplitude of $0.1 \mathrm{~m}$ to the finite height takes between 25 and 230 years, depending on the conditions. Including suspended sediment reduces this time with 0-40 years.

Except for the runs 15 and 16, the tidal flow was symmetric and no migration occurred. When including the residual current, the sand waves do migrate. 
The migration rate increases from $3 \mathrm{~m} / \mathrm{y}$ to $4 \mathrm{~m} / \mathrm{y}$ when suspended sediment is included.

\subsection{Discussion}

\subsubsection{Model results}

The results in the previous section show that suspended sediment can affect the sand waves. The sand waves grow on average 15 years faster towards their final shape. Their height is reduced (on average 4\%) and their length becomes around 10\% shorter. Also the crest/trough ratio changes. Regarding the sand wave length we observe that the crest gets more peaked and the trough becomes longer. The crest/trough ratio for the sand wave length decreases on average with $3 \%$ making the sand wave more asymmetric (i.e. the crest length becomes even smaller compared to the trough length). As for the sand wave height, the crest/trough ratio either increases or decreases depending on the reduction of both the crest amplitude and the trough amplitude. In most cases this results in an slight decrease of the sand wave asymmetry, when including suspended sediment.

The suspended sediment effect depends on the conditions. When investigating the varied parameters (Tables 4.2 and 4.3), we need to distinguish between the effect of the parameter itself on the sand wave, and the effect of the parameter on the suspended sediment transport and through that again on the sand wave.

The effect of grain size on sand waves is negligible without suspended sediment transport. The suspended sediment transport increases when the grain size decreases (wave length and height decrease more, see Figure 4.9) because the ratio of $Q_{b} / Q_{s}$ increases. The reason for the effect is that the smaller grains are entrained more easily, and so increase the suspended sediment transport. This increase has a relatively small influence on the sand wave evolution and final state. The used grain sizes represent the sediment range in which sand waves occur in the North Sea. Within this range, changes have less effect than in the fine sand/silt/clay grain sizes, that are often referred to when dealing with suspended sediment. However, sand waves do not occur in areas where clay is present (see e.g. Hulscher and Van den Brink, 2001; Borsje et al., 2009). The effect of a grain mixture and possible grain size sorting on this processes is subject to further research.

Shallower water reduces both the sand wave length and the crest height of the sand wave. Note that the model predicts an (unrealistic) deepening of the troughs, which is stronger in shallower water. Further investigation for other water depths shows that the trough deepening increases for both very shallow water and very deep water. Suspended sediment transport reduces both the sand wave length and the total amplitude. The effect is largest for deep water; in the case without suspended sediment (run 3) the sand wave crest continues growing to a higher final height, while with suspended sediment (run 4) the height stays roughly the same compared to other water depths. The continuous 
growth for run 3 also results in an crest/trough ratio for the sand wave length that increases when suspended sediment is included. The explanation of these deep water results should be searched more in the model conditions in run 3 than in physics. Due to the stable conditions the sand wave can continue to grow higher in case 3, while a small disturbance such as including suspended sediment is enough to change the equilibrium height to a more realistic value. This effect of small disturbances is also found in Chapter 3.

A decreasing flow velocity has the same effect on sand waves as decreasing the water depth. When taking into account suspended sediment transport, this has slightly more effect for higher flow velocities. Due to the higher flow velocity at the bed the suspended sediment increases, leading to more transport. As the bed load transport also increases with higher flow velocities, the effect on the $Q_{b} / Q_{s}$ ratio is small.

Flow velocity increases the suspended sediment impact most when the flow becomes asymmetric. The large influence of an asymmetric tide was already shown in Chapter 2, now we see that it not only influences the sand wave directly but also by enhancing the suspended sediment effects. The sand wave length and height are reduced by $4 \%$ and $14 \%$ respectively when a residual current is included without suspended sediment (run 1 and run 15). With suspended sediment on top of that (run 15 and run 16) reduces the length and height further with an extra $14 \%$ and $8 \%$ respectively. Where the residual current mostly affects the sand wave height, the suspended sediment has more influence on the sand wave length. Opposite to the symmetric cases, here the crest/trough ratio for the sand wave length increases when suspended sediment is taken into account. Due to the migration of the sand waves the sediment is no longer transported to the crests, but to the flanks. The result is a more symmetric sand wave height and length and gentler slopes.

The sand wave migration due to an asymmetric current is increased when including suspended sediment. Similar as for the growth rate, the migration is increased by suspended sediment as it includes an extra transport process. Suspended sediment does not so much change the processes but it merely increases the speed. This can be explained from the fact that the suspended sediment is not entrained high in the water column. Firstly, this results in low transport rates as only a small part of the water column is used. Secondly, as the suspended sediment is transported close to the bed, it behaves rather similar to the bed load (e.g. no lag effects).

In this study we explore only the basis processes involved in sand wave evolution in combination with suspended sediment transport. Our main goal is to explore the effects of the suspended sediment process on the long term morphology and dynamics of sand waves. However further extension of the model, e.g. with surface waves and grain size mixtures, will increase the comparability of the model results with observed sand waves. 


\subsubsection{Sediment concentrations}

Under all conditions tested in this chapter, the suspended sediment transport is modest compared to the bed load transport. However, the effect on the long term sand wave evolution can be significant. The suspended sediment transport rates are small in a sand wave environment because (1) the grain sizes are relatively large, i.e., the sediment is sand and not silt or clay and (2) the water is relatively deep. This strongly reduces the amount of sediment in suspension and the height up to which the sediment is transported in the water column. Green et al. (2000) shows the large differences between sand and silt. Sand entrains both less and less high in the water column, and can be treated as a local process, while this is not the case with silt suspension. In the North Sea e.g. Gerritsen et al. (2001) shows that suspended sediment can be high up in the water column, but they restrict their data and modelling to sediment with a diameter smaller than $63 \mu \mathrm{m}$ (i.e. clay). Measurements by Grasmeijer et al. (2005) show hardly any sediment in suspension on deeper parts of the North Sea, except during storms. In their measurements (water depth around $14 \mathrm{~m}$ ) they found maximum sediment concentrations of $2.3 \mathrm{~km} / \mathrm{m}^{3}$ during a storm at $30 \mathrm{~cm}$ above the bed decreasing to $0.2 \mathrm{~kg} / \mathrm{m}^{3}$ at $1 \mathrm{~m}$ above the bed. During calm weather, concentrations were around $0-0.2 \mathrm{~kg} / \mathrm{m}^{3}$ close to the bed. This compares relatively well with the maximum values of $30 \mathrm{mg} / 1\left(0.03 \mathrm{~kg} / \mathrm{m}^{3}\right)$ found in the presented model results. In the model results no surface waves are included and the water depth is deeper leading to lower sediment concentrations. Green et al. (1995) found that, even during a severe storm, only a small percentage of the sediment was entrained more than half a metre above the bed (bimodal sediment with grain sizes 25 and $100 \mu \mathrm{m}$, in the North Sea), which coincides with the predicted model values.

Qualitatively the presented model results are consistent with the results of Blondeaux and Vittori (2005b), who found that suspended sediment was negligible for grain sizes around $0.25 \mathrm{~mm}$. For smaller grain sizes $(0.0625 \mathrm{~mm})$ Blondeaux and Vittori (2005b) predicted a significant contribution of suspended sediment transport. However, sand waves hardly occur in areas in which such fine sediments are dominant (Hulscher and Van den Brink, 2001). As their model is only able to describe linear sand wave characteristics (the sand wave length and initial migration), Blondeaux and Vittori (2005b) are unable to predict whether the long term sand wave evolution can be affected by a small contribution of suspended sediment. Besides Blondeaux and Vittori (2005b) do not investigate the individual effects of suspended and bed load transport on the sea bed morphodynamics.

In the field the conditions under which sand waves are present are less stable and influenced by more processes than currently modelled. These processes, such as surface waves, will affect the sand waves morphology and dynamics. Sterlini et al. (2009a) (Chapter 3) already shows that surface waves can affect sand waves considerably. Due to possible interactions and non linearities between suspended sediment and surface waves, the effects are not easy to predict. Further research will focus on the combination of surface waves and suspended 
sediment over sand waves.

\subsubsection{Uncertainties}

Note that, compared to observations, the shown model results overestimates the sand wave height (e.g. Terwindt (1971); Knaapen (2005) and Van Dijk and Kleinhans (2005)). However, the values compare well with the maximum values according to Flemming (2000) and de Koning (2007). The lower field values can for example be the result of a more asymmetric current (Chapter 2 Sterlini et al., 2009b) or the influence of surface waves (Chapter 3 Sterlini et al., 2009a). However, lower sand waves do not change the suspended sediment effects except for reducing the transport rates further due to smaller changes in the water depth. Besides, to study the suspended sediment effects, inclusion of surface waves would make the understanding of the individual processes and their effects more complicated.

The accuracy for the sand wave length results is determined by the 20 increments used to obtain the FGM. The sand wave height is accurate to approximately $1 \mathrm{~m}$. The reference height for suspended sediment is set at $1 \%$ of the water depth in the model. In $30 \mathrm{~m}$ water depth this already means a reference height of $30 \mathrm{~cm}$ above the bed. However, field observations show that even in severe storms the suspended sediment is suspended mostly in the first half a metre about the bed. Possibly, the use of the relatively high reference height underestimates the suspended sediment.

In water depth deeper than $35 \mathrm{~m}$ and with a low flow velocity, the model showed instabilities in the FGM when suspended sediment was included. The cause for this is not clear. The instabilities did not occur without suspended sediment, and became less when the water depth was decreased. For the bed load transport the critical shear stress is neglected. Further research will investigate the effect of this assumption. Possibly the ratio between $Q_{b}$ and $Q_{s}$ will decrease and the effect of suspended sediment might increase. Note however that part of the critical shear stress is incorporated in the value of $\lambda$ (Van den Berg, 2007).

Also the horizontal flow component in the advection diffusion equation (Equation: 4.12) is neglected. Simulations including this term, confirm it can be neglected as the results do not change.

\subsection{Conclusion}

In this chapter we have investigated the effect of suspended sediment on sand waves in a calm weather environment. A deterministic model is used to investigate which environmental conditions influence the occurrence of suspended sediment and what the effects on sand wave morphology and dynamics are. The simulations show that suspended sediment in general (1) shortens and lowers the sand waves, (2) increases the growth and migration rate and (3) decreases the crest/trough ratio for the sand wave length and height. The qualitative effect of suspended sediment is robust under variation of the water depth and 
the grain size. Decreasing the grain size, increasing the current, or changing it from symmetric to asymmetric, increases the quantitative suspended sediment effects. Although the suspended sediment transport is modest compared to the bed load transport, it can significantly affect the long term sand wave evolution and final shape. The predicted concentrations are reasonable when compared with observations under sand wave conditions. Further research is carried out to extend the presented results to rough weather conditions. 


\title{
Chapter 5
}

\section{Modelling grain size sorting during offshore sand wave evolution ${ }^{1}$}

\begin{abstract}
Offshore sand waves are rhythmic bed patterns widely present in shallow shelf seas. Observations from the North Sea indicate a trend of coarser sediment with a higher sorting at sand wave crests. In this study, we present an extended model for sand wave dynamics that accounts for the presence and transport of non-uniform sediment. The extension involves an active layer as well as a fractional calculation of sediment transport, which includes hidingexposure effects. Simulations of a growing sand wave for a bimodal mixture indicate a coarsening trend towards the crest. In the sand wave troughs the sediment remains mixed during the sand wave evolution and becomes finer when the sand wave growth decreases. The heterogeneous sediment has no significant effect on the sand wave height and length. The model results show qualitative agreement with observations from various sites in the North Sea.
\end{abstract}

\section{$5.1 \quad$ Introduction}

Shelf seas are generally some tens of metres deep and are often extensively used for human activities such as sand mining and navigation. Where the sea bed consist of sand, the sea bed is hardly ever flat and highly non-uniform. For example, grain sizes are variable between locations, and within a region often a mixture of different grain sizes exists. In addition, the bed consists of bed forms, including large scale bed forms such as sand waves. The combination of these grain size mixtures and sand waves, are subject of this chapter.

We will focus on sand waves, which are characterized by a wave height up to several metres, wave lengths of $100-900 \mathrm{~m}$ and a possible migration rate up to 5 $10 \mathrm{~m} / \mathrm{y}$. They occur in water depth of $10-40 \mathrm{~m}$, showing highly variable shapes, from symmetric sinusoidal like waves to asymmetric triangular shapes. Sand waves have been observed for several decades (e.g. McCave (1971); Terwindt (1971) and more recently by Passchier and Kleinhans (2005); Van Dijk and

\footnotetext{
${ }^{1}$ This chapter is adapted after Roos, P.C., Hulscher, S.J.M.H., Meer, F.M. v.d., Dijk, T.A.G.P. v.,Wientjes, I.G.M., and Berg, J. v.d.(2007). Grain size sorting over offshore sand waves: observations and modelling. In: River, Coastal and Estuarine Morphodynamics: RCEM 2007, Dohmen-Janssen, C.M. and Hulscher, S.J.M.H.(eds.). Taylor \& Francis Group, London.
} 
Kleinhans (2005) and Dorst et al. (2007)). Due to their size and their dynamics, they may interfere with human structures such as pipelines and navigation channels.

The variation in grain sizes over sand waves is subject of study as long as sand waves are observed (e.g. Terwindt, 1971) but gained interest over the past years, not at least because of the increased accuracy and possibilities in observation techniques. In general the field observations show that on the top of sand waves the sediment is better sorted and coarser than in the troughs. However, also shifts towards the flanks or even to the troughs are observed, as well as no obvious sorting at all. For example, Passchier and Kleinhans (2005) and Passchier (2004) observed that grain sizes were different between the trough and crest of sand waves, but only during parts of the year. After storm periods the troughs were finer and poorer sorted than the crests of the sand waves, while after a calm period the grain sizes were roughly the same. A distribution of coarser crests and finer troughs was reported by Terwindt (1971), sampling the top layer of sea bed over sand waves. In Section 5.2, we show for locations on the North Sea that the differences in grain sizes are often small and sorting is not always found.

Model studies investigating sand waves mostly consist of homogeneous sediment. This means that both the sorting process and its possible influence on the bed forms are excluded. An interesting exception is the recent work of Van Oyen and Blondeaux (2009), who extend a linear sand wave model with graded sediment. They show that the sorting over sand waves in the linear regime (i.e. for sinusoidal sand wave with infinitesimal small heights) can result in either a coarsening or a fining of the sand wave crest, depending on the conditions. Still, with their model no information can be found for the non linear sand wave regime, i.e. for realistic sand wave shapes and heights.

In this chapter we extend an existing non-linear sand wave model with different grain size classes to describe sorting, including an active layer model and hiding exposure. The model is able to simulate sand wave evolution including the non-linear part and the sorting of sediment over the sand wave during this evolution. We use the model to investigate the sensitivity of sorting processes to changes in environmental factors and sediment characteristics. Besides, we investigate the effect of the sorting processes on the sand wave evolution.

The paper is organised as follows, we first give an overview of grain size patterns over tidal sand waves as observed at various locations in the Southern North Sea (Section 5.2). In Section 5.3, we present a morphodynamic sand wave model that accounts for the presence and transport of non-uniform sediment. It is based on an existing nonlinear numerical sand wave simulation model by Van den Berg and Van Damme (2006), which we have extended in the following respects: the introduction of an active layer after Hirano (1971) and a fractional calculation of sediment transport, including hiding-exposure effects. Section 5.4 contains the model results which are further discussed in Section 5.5. Finally, Section 5.6 contains the conclusions. 

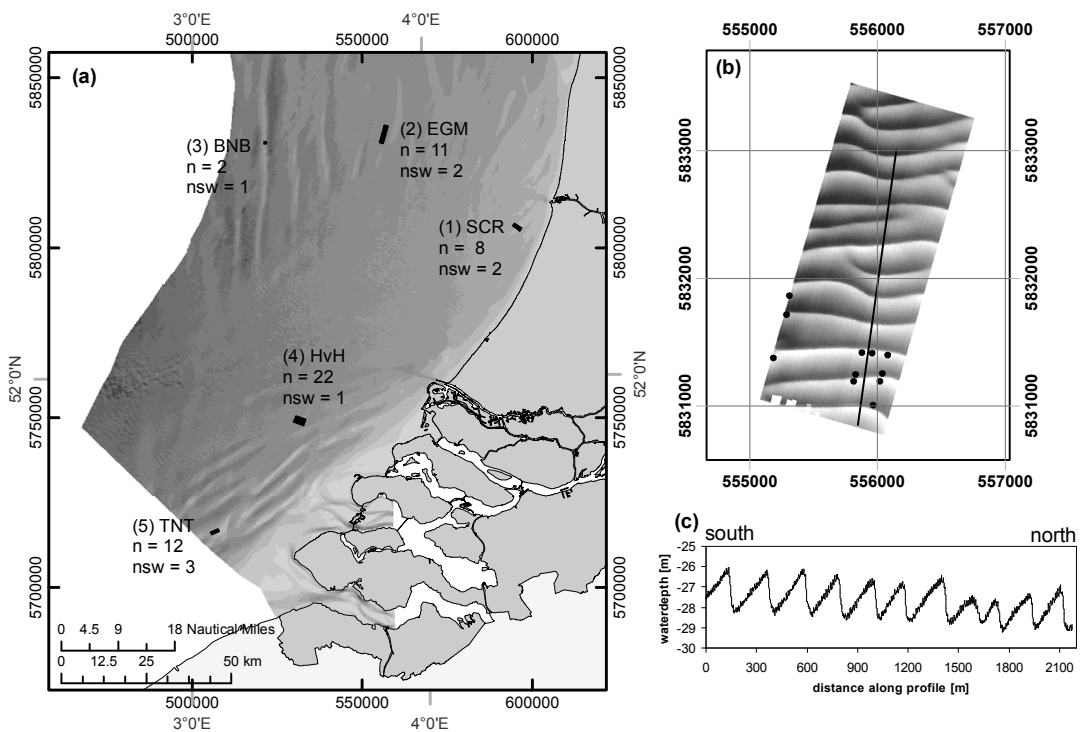

Figure 5.1: (a) Location map of study sites with bathymetry in the southern North Sea, with $n$ the number of samples per site and $n s w$ the number of sand waves covered by the sampling. (b) Multibeam echo sounding image of site 2 with sample locations and (c) a cross-sectional profile.

\subsection{Observations from the North Sea}

\subsubsection{Data Collection and Processing}

Grain size variability over sand waves is observed at several locations of different water depths, sand wave morphology and flow conditions in the North Sea. At five sites, sampling strategies were especially designed to record grain size patterns over sand waves. Samples were taken at crests, in troughs and in most cases also on the slopes of sand waves (Figure 5.1). Sea bed sampling was carried out using a cylindrical box corer, of which sediment cores were resampled on board, except for site 4, where a vibrocorer was used. Grain size distributions of sea bed subsamples were determined in the lab by laser diffraction, using a Malvern 2000, for grain sizes smaller than $2 \mathrm{~mm}$ after sieving off the coarser material. All samples fall within the sand fraction, i.e. noncohesive sediment. The sand waves at all sites are compound sand waves, i.e. sand waves with superimposed megaripples. They furthermore display migration, with migration rates that differ from site to site.

\subsubsection{Site-Specific Characteristics}

Site 1 is a coastal site near Zandvoort, where three-dimensional sand waves are superimposed on and restricted to a shoreface-connected ridge ('SCR'). These sand waves are asymmetric in cross-sectional profile, with their lee slopes facing north-east. Water depths at this site range from $14 \mathrm{~m}$ on top of the ridge to 


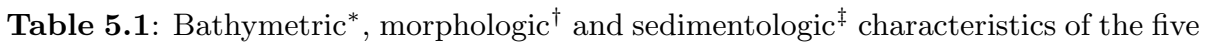
North Sea sites in Figure 5.1.

\begin{tabular}{l|ccccc}
\hline site & $(1) \mathrm{SCR}$ & $(2)$ EGM & $(3) \mathrm{BNB}$ & $(4) \mathrm{HvH}$ & $(5) \mathrm{TNT}$ \\
\hline$H[\mathrm{~m}]$ & $14-18$ & $26-30$ & $17-44$ & $19-28$ & $11-37$ \\
$L_{\mathrm{sw}, \text { avg }}[\mathrm{m}]$ & 760 & 203 & 206 & 350 & 145 \\
$H_{\mathrm{sw}, \text { avg }}[\mathrm{m}]$ & 1.5 & 1.8 & 2.5 & 7.3 & 3.9 \\
$D_{50, \mathrm{cr}}[\mu \mathrm{m}]$ & $342-351$ & $273-297$ & 314 & $396-561$ & $397-421$ \\
$D_{50, \text { tr }}[\mu \mathrm{m}]$ & $319-321$ & $254-272$ & 316 & $303-461$ & $436-530$ \\
$D_{50, \text { sl }}[\mu \mathrm{m}]$ & $323-360$ &. &. & $370-506$ & $378-551$ \\
$\left(D_{60} / D_{10}\right)_{\mathrm{cr}}[-]$ & $1.47-1.48$ & $1.48-1.54$ & 1.44 & $1.54-1.77$ & $1.56-1.69$ \\
$\left(D_{60} / D_{10}\right)_{\mathrm{tr}}[-]$ & $1.48-1.49$ & $1.53-1.54$ & 1.46 & $1.55-1.80$ & $1.61-13.3$ \\
$\left(D_{60} / D_{10}\right)_{\mathrm{sl}}[-]$ & $1.47-1.49$ &. &. & $1.55-1.63$ & $1.62-10.5$ \\
\hline
\end{tabular}

*Approximate range in water depth; ${ }^{\dagger}$ average sand wave length $L_{\mathrm{sw} \text {,avg }}$ and height $H_{\mathrm{sw} \text {,avg }} ;{ }^{\ddagger}$ median grain size $D_{50}$ and sorting ratios $D_{60} / D_{10}$, for the crests ('cr'), the troughs ('tr') and the slopes ('sl'), respectively.

$18.3 \mathrm{~m}$ in the adjacent swales. The one sand wave that is fully covered with multibeam echo sounding measurements has a wavelength of $760 \mathrm{~m}$ and a wave height of $1.5 \mathrm{~m}$. In contrast with sand waves in other locations, these have flattened crest plateaus. Median grain sizes $\left(D_{50}\right)$ at the crest plateaus range from 340 to $350 \mu \mathrm{m}$ between samples; sorting ratios $\left(D_{60} / D_{10}\right)$ are 1.47 or 1.48 . Median grain sizes in the troughs vary between 219 and $327 \mu \mathrm{m}$ and sorting ratios are similar to those at the crests, 1.48 and 1.49 (March 2001).

Site 2 is a sand wave field $50 \mathrm{~km}$ offshore of Egmond aan Zee ('EGM') and comprises straight, asymmetrical sand waves (see Figure $5.1 \mathrm{~b}$ and c) with an average wavelength of $203 \mathrm{~m}$, an average wave height of $1.8 \mathrm{~m}$ and their lee slopes facing north-northeast (Van Dijk and Kleinhans, 2005). Here, water depths range from 26 to $30 \mathrm{~m}$. Median grain sizes (June 2001) vary from 273 to $297 \mu \mathrm{m}$ at the crests and from 254 to $272 \mu \mathrm{m}$ in the troughs. Sorting ratios are 1.48 to 1.54 (only one of 1.54) at the crests and 1.53 to 1.54 in the troughs.

Site 3 comprises offshore sand waves on a tidal ridge, the Brown Bank ('BNB'), where water depths vary between $17 \mathrm{~m}$ at the top of the ridge and $44 \mathrm{~m}$ in the swales. Here, sand waves are asymmetrical with their lee sides facing northeast and have an average wavelength of $206 \mathrm{~m}$ and an average wave height of $2.5 \mathrm{~m}$. Only one sand wave was sampled at this site (November 2006), resulting in a median of $314 \mu \mathrm{m}$ at the crest and $316 \mu \mathrm{m}$ in the trough. The sorting ratios are 1.44 and 1.46 at the crest and in the trough, respectively.

Site 4 is located $45 \mathrm{~km}$ west-southwest of Hoek van Holland ('HvH'), where sand waves are more symmetric and have steeper sides and wide gentle troughs. Area-covering multibeam echo soundings of one sand wave show that its wavelength is approximately $350 \mathrm{~m}$ and its wave height is up to $7.3 \mathrm{~m}$. Water depths range from 19 to $28 \mathrm{~m}$. Median grain sizes (April 2001) vary from 396 to $561 \mu \mathrm{m}$ at the crest and from 303 to $461 \mu \mathrm{m}$ in the troughs. Sorting ratios are between 1.54 and 1.77 at the crest and between 1.55 and 1.80 in the troughs (Schüttenhelm, 2002). 

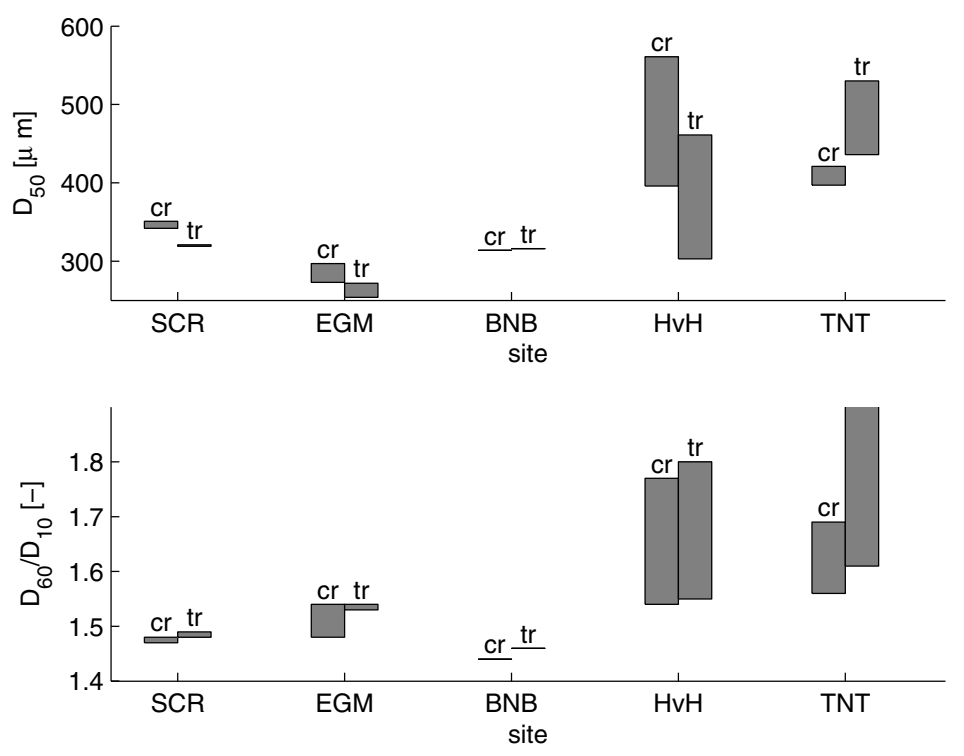

Figure 5.2: The median grain size $D_{50}$ and the sorting ratio, $D_{60} / D_{10}$, per morphological sand wave unit for five study sites in the North Sea. The maximum of site 5 (TNT, see Table 5.1) fall outside the plot.

Site 5 reveals sand waves on a tidal ridge Thornton Bank ('TNT'), where water depths range from $11 \mathrm{~m}$ over the bank to $37 \mathrm{~m}$ in the swales. The sand waves are symmetric in cross-sectional profile and have relatively steep slopes. Their average wavelength is $145 \mathrm{~m}$ and their heights are 1.0 to $6.9 \mathrm{~m}$, with an average of $3.9 \mathrm{~m}$. Median grain sizes at the sand wave crests (October 2006) range from 397 to $421 \mu \mathrm{m}$ and in the troughs from 436 to $530 \mu \mathrm{m}$. Sorting ratios are 1.56 to 1.69 at the crests and 1.61 to an exceptional 13.3 in the troughs. In general, grain sizes show more variability than at the other sites.

An overview of bathymetric, morphologic and sedimentologic characteristics is provided in Table 5.1. The sand wave dimensions at sites 1, 2, 3 and 5 have been calculated with a semi-automated method (van Dijk et al., 2006) from digital multibeam echo soundings; at site 4 this was done manually.

\subsubsection{Conclusions on Observed Sorting Patterns}

The existence of grain size variability patterns over sand waves is evident from the clustering in grain size characteristics per morphological unit of sand waves (Figure 5.2). Although exceptions exist and grain size variability over sand waves may be less clear per season at sites where sampling was done in seasonal time series, grain size differences between crests and troughs of offshore sand waves, although subtle, show a general trend of coarser and well-sorted sedi- 
ments (lower sorting ratios) at the sand wave crests and finer-grained and less well-sorted sediments in the troughs (Figure 5.2).

\subsection{Morphodynamic Model}

\subsubsection{Geometry}

Consider a two-dimensional coordinate system with a horizontal $x$-axis, and a vertical $z$-axis pointing upward (with $z=0$ denoting the spatial average of the bed level). The sea bed is located at $z=\eta(x, t)$, which defines the top of a so-called active layer to be introduced below. The free surface is at $z=\zeta(x, t)+H_{0}$ where the constant $H_{0}$ represents the undisturbed water depth (here: $H_{0}=30 \mathrm{~m}$ ).

The flow velocity is represented by the vector quantity $\boldsymbol{u}=(u, w)$, with components in $x$ - and $z$-direction respectively. Regarding the horizontal coordinate we assume spatial periodicity, effectively imposing the wavelength $L$ of the sand waves, which is then kept constant throughout each morphodynamic simulation. See Figure 5.3 for a sketch.

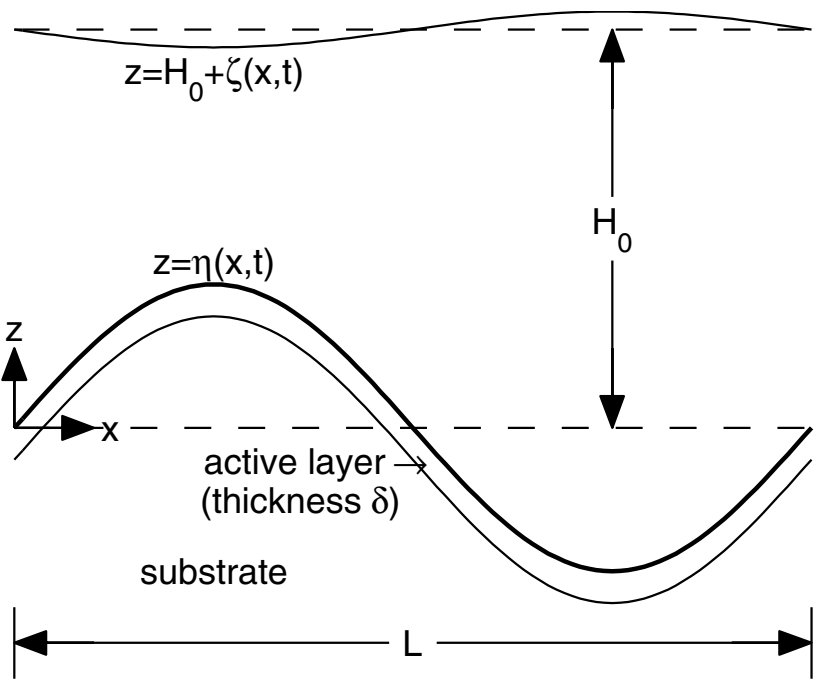

Figure 5.3: Definition sketch of model geometry, for clarity strongly exaggerating the vertical scale and the active layer thickness.

\subsubsection{Hydrodynamics and Solution Method}

The hydrodynamic module is based on the 2DV-shallow water equations (assuming hydrostatic pressure) and with a Boussinesq turbulence closure involving a constant value of the vertical eddy viscosity $A_{\mathrm{v}}=0.03 \mathrm{~m}^{2} \mathrm{~s}^{-1}$. Kinematic boundary conditions are imposed at the free surface and at the sea bed. 
Furthermore, dynamic boundary conditions require zero stress at the free surface $\left(\frac{\partial u}{\partial z}=0\right)$ and partial slip at the bed $\left(A_{\mathrm{v}} \frac{\partial u}{\partial z}=S u\right)$, with slip parameter $S=0.01 \mathrm{~m} \mathrm{~s}^{-1}$. A time-dependent body force is added to the momentum equations in order to mimic the forcing that drives the tidal flow in the domain. This pressure gradient is chosen such that, over a flat bed, it induces a sinusoidal tidal flow with a depth-averaged peak value of $1 \mathrm{~m} \mathrm{~s}^{-1}$ and a period of $12.42 \mathrm{hrs}$ (M2-component). More details on the hydrodynamic model formulation as well as the numerical solution procedure can be found in Van den Berg and Van Damme (2006).

For a given bed profile $\eta$, the main output of the hydrodynamic module is the bed shear stress:

$$
\tau_{\mathrm{b}}(x, t)=\left.\rho A_{\mathrm{v}} \frac{\partial u}{\partial z}\right|_{z=\eta} .
$$

This quantity, varying over the domain and within the tidal cycle, is then used as input for the sediment transport module.

\subsubsection{Sediment, Active Layer and Bed Evolution}

We consider a noncohesive sediment mixture that consists of $N$ distinct fractions of grain size $D_{j}(j=1,2, \ldots, N)$. Following Hirano (1971), the sea bed is divided into an active layer of constant and uniform thickness $\delta$ (located at $\eta-\delta \leq z \leq \eta)$ and a substrate $(z<\eta-\delta$; see Figure 5.3). Each of these layers is characterized by volume fractions for the grain size classes $j: F_{j}(x, t)$ in the active layer, which may vary in space and time; $F_{\text {substr }, j}$ for the substrate, assumed uniform and constant. By definition, these fractions must add up to 1, i.e. $\sum_{j} F_{j}=1$ and $\sum_{j} F_{\text {substr }, j}=1$ (all summations from $j=1$ to $j=N$ ). Moreover, the mean grain size in the active layer is given by $D_{\mathrm{m}}=\sum_{j} F_{j} D_{j}$. By assuming a constant and uniform active layer thickness, we ignore situations in which a non-erodible substrate is locally exposed at the sea bed $(\delta=0)$.

Only the active layer contains material directly available for transport. By moving up and down, the active layer interacts with the substrate. For example, deposition implies an increase of the bed level in time. In turn, the active layer (of constant thickness $\delta$ ) shifts upward, which implies a vertical exchange of sediment from the active layer into the substrate. Conversely, erosion shifts the active layer downward, implying a sediment exchange from substrate into the active layer. This is the indirect mechanism by which the substrate may interact with the flow, sediment transport and bed evolution.

With $q_{j}$ denoting the volumetric bed load sediment flux (in $\mathrm{m}^{2} \mathrm{~s}^{-1}$ ) of sediment fraction $j$ in the $x$-direction and $\left\langle q_{j}\right\rangle$ its tidally averaged value, sediment fraction $j$ satisfies the following conservation law (Seminara, 1995):

$$
\delta \frac{\partial F_{j}}{\partial t}+F_{\text {vert }, j} \frac{\partial \eta}{\partial t}=\frac{-1}{1-p} \frac{\partial\left\langle q_{j}\right\rangle}{\partial x},
$$

with porosity $p=0.4$. The volume fractions $F_{\text {vert }, j}$ associated with the vertical sediment exchange between active layer and substrate (as explained above) are 
given by

$$
F_{\text {vert }, j}= \begin{cases}F_{j} & \text { if } \partial \eta / \partial t>0 \\ F_{\text {substr }, j} & \text { if } \partial \eta / \partial t<0 .\end{cases}
$$

Therefore, also the vertical exchange fractions add up to 1. Summation of the conservation law (5.2) now leads to an overall sediment balance

$$
\frac{\partial \eta}{\partial t}=\frac{-1}{1-p} \frac{\partial\left\langle q_{\mathrm{tot}}\right\rangle}{\partial x}, \quad q_{\mathrm{tot}}=\sum_{j=1}^{N} q_{j},
$$

which expresses the local bed change $\partial \eta / \partial t$ in terms of the divergence of the (tidally averaged) total sediment flux.

\subsubsection{Fractional Sediment Transport}

The fractional sediment flux $q_{j}$ is calculated from a modified version of the Meyer-Peter \& Müller formula (Van Rijn, 1993), accounting for bed slope effects:

$$
\frac{q_{j}}{\sqrt{g(s-1) D_{\mathrm{j}}^{3}}}=8 F_{j}\left(\left|\theta_{j}\right|-\theta_{\mathrm{cr}, j}\right)^{\frac{3}{2}}\left(\frac{\tau_{\mathrm{b}}}{\left|\tau_{\mathrm{b}}\right|}-\frac{1}{\mu_{\mathrm{s}}} \frac{\partial \eta}{\partial x}\right),
$$

for conditions above the threshold of transport $\left(\left|\theta_{j}\right|>\theta_{\mathrm{cr}, j}\right)$ and $q_{j}=0$ otherwise. Here, $\theta_{j}=\tau_{\mathrm{b}} /\left[\rho(s-1) g D_{j}\right]$ is the Shields parameter and $\theta_{\mathrm{cr}, j}$ the critical Shields stress, both for class $j$. The latter is expressed as a correction to the critical Shields parameter $\theta_{\mathrm{cr}, \mathrm{m}}$ (based on the mean grain size), with a so-called hiding-exposure coefficient $\xi_{j}$ :

$$
\theta_{\mathrm{cr}, j}=\xi_{j} \theta_{\mathrm{cr}, \mathrm{m}}, \quad \xi_{j}=\left[\frac{\log 19}{\log \left(19 D_{j} / D_{\mathrm{m}}\right)}\right]^{2} .
$$

This formulation, proposed by Egiazaroff (1965), describes the hiding-exposure mechanism experienced by grains in a sediment mixture. In the presence of finer grains, coarser grains protrude relatively further into the flow and are therefore more easily transported than in a situation with uniform sediment: exposure $\left(\xi_{j}<1\right.$, thus reducing the threshold for initiation of sediment transport). Conversely, fine grains hide behind and between coarser grains and are therefore less easily transported: hiding $\left(\xi_{j}>1\right.$, increasing the threshold).

The critical Shields parameter $\theta_{\mathrm{cr}, \mathrm{m}}$, based on the mean grain size, is given by Soulsby (1997)

$$
\theta_{\mathrm{cr}, \mathrm{m}}=\frac{0.24}{D_{\mathrm{m}}^{*}}+0.055\left[1-\exp \left(0.02 D_{\mathrm{m}}^{*}\right)\right],
$$

with dimensionless grain size $D_{\mathrm{m}}^{*}=\left[g(s-1) / \nu^{2}\right]^{1 / 3} D_{\mathrm{m}}$. The remaining parameters in equations (5.5) and (5.7) are the specific gravity of sediment $s=1.65$, the gravitational acceleration $g=9.81 \mathrm{~m} \mathrm{~s}^{-2}$, a coefficient of static friction $\mu_{\mathrm{s}}=0.3$, and (in the definition of $D_{\mathrm{m}}^{*}$ ) the kinematic viscosity of water $\nu=$ $1.36 \cdot 10^{-6} \mathrm{~m}^{2} \mathrm{~s}^{-1}$. 


\subsubsection{Solution Procedure}

For a given bed profile $\eta$, the bed shear stress $\tau_{\mathrm{b}}$ is known from the hydrodynamic module. For each sediment class $j$, the transport formula (5.5) is then used to obtain the (tidally averaged) fractional sediment transport $\left\langle q_{j}\right\rangle$, as a function of space.

Next, from the overall sediment balance (5.4) the local bed change $\partial \eta / \partial t$ is obtained. The sign of this quantity particularly shows whether, locally, sedimentation or erosion occurs. This result is required to determine the local exchange fractions $F_{\text {vert }, j}$ from equation (5.3). The individual sediment balances (5.2) then provide $\partial F_{j} / \partial t$, i.e. the evolution of the individual fractions in time. For details on the numerical discretization of the sediment transport module, we refer to Wientjes (2006).

\subsection{Results}

\subsubsection{Overview of Simulations}

In the following, we present the results obtained with the morphodynamic model. In the first part we focus on the influence of the parameters that characterize the composition of the sediment mixture. To this end, we introduce a bimodal sediment mixture, consisting of coarse and fine grains (Section 5.4.2). Next, a second simulation is carried out, in which we consider the more simple situation of uniform sediment (Section 5.4.3). These two simulations allow us to investigate the effect of the non-homogeneity of the sediment mixture. To study the sensitivity of the model results, we make runs in which the bimodal sediment composition is further modified (Section 5.4.4).

In Section 5.4.5 we investigate the sensitivity of the sorting processes to the water depth and the flow velocity to test the robustness of the found processes.

All model parameter values are as specified in Section 5.3. The wavelength $L$ is estimated such that, for small amplitude, the growth rate of the corresponding sand wave is strongest (fastest growing mode). For the reference simulation, this procedure leads to $L=650 \mathrm{~m}$. Although the fastest growing mode may shift when a different sediment mixture is considered, it turns out that this dependency of the preferred wavelength on the sediment mixture is rather weak. In Section 5.4.5 the variation in the preferred wavelength is taken into account as it is affected significantly by varying the water depth and flow velocity.

The sea bed profile $z=\eta$ at $t=0$, i.e. the initial topography, is chosen sinusoidal with wavelength $L$ and a small amplitude that is $1 \%$ of the mean water depth $H_{0}$ (here: $0.3 \mathrm{~m}$ ). The instability mechanism will cause the bed feature to grow in time and to develop into a sand wave (Hulscher, 1996).

\subsubsection{Simulation with a Bimodal Mixture}

We consider a bimodal mixture $(N=2)$ with the following grain sizes, labeled 'coa' (coarse) and 'fi' (fine): $D_{\text {coa }}=400 \mu \mathrm{m}, D_{\text {fi }}=200 \mu \mathrm{m}$, which agrees with the observed grain sizes as reported in Section 5.2. Initially, the active layer and the substrate are both assumed perfectly mixed, with the coarse and fine 
fraction equally present: $F_{\text {coa }}=F_{\text {fi }}=\frac{1}{2}$ and $F_{\text {substr,coa }}=F_{\text {substr,fi }}=\frac{1}{2}$. The mean grain size thus equals $D_{\mathrm{m}}=300 \mu \mathrm{m}$. The active layer thickness is taken as $2 \mathrm{~cm})$.
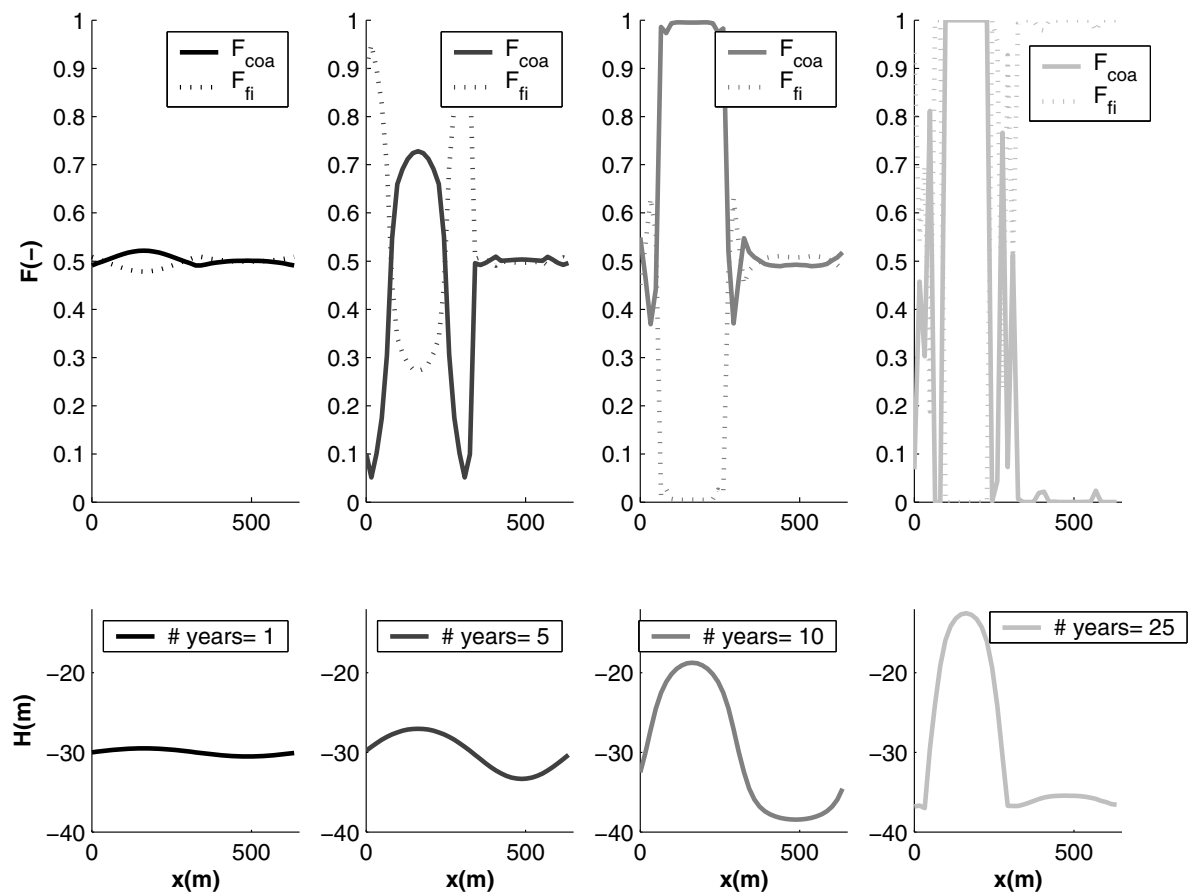

Figure 5.4: Evolution of the coarse and fine grain fraction in the active layer (top) as well as the cross-sectional sand wave morphology (bottom). Both quantities are plotted against the spatial coordinate $x$, at different times: (a) after 1 year, (b) 5 year, (c) 10 years, (d) 25 years. Note: $F_{\text {fi }}=1-F_{\text {coa }}$.

As shown in Figure 5.4, a sand wave evolves, starting from a sinusoidal shape and then gradually deforming towards an equilibrium profile. This profile has a peaked and relatively narrow crest (about $18 \mathrm{~m}$ high), compared to the flattened and relatively wide trough (about $6 \mathrm{~m}$ below mean bed level). The growth of the sand wave is accompanied by a continuous redistribution of fine and coarse grains. The concentration of coarse grains increases at the crests, reaching its maximum of $F_{\text {coa }}=1$ after about ten years. The trough remains well-mixed, nearly identical to the sediment composition of the substrate.

After about 50 years, the simulation collapses after displaying instabilities at the transition point between erosion and deposition of the evolving sand wave (see Section 5.5.1). The simulation suggests that, although the sand wave shape hardly changes, a redistribution of fine and coarse grains is then taking place in the trough. Therefore, an equilibrium state is not reached. 


\subsubsection{Simulation with Uniform Sediment}

In a second simulation, the sediment in the active layer and substrate consists of a single class $(N=1)$ with grain size equal to the mean grain size of the previous run: $D_{1}=300 \mu \mathrm{m}$. Trivially, $D_{\mathrm{m}}=D_{1}$ and the volume fraction equals 1 , for all $x$ and $t$. In this case, there is effectively no distinction between the active layer and the substrate, so the layer thickness $\delta$ has no meaning here. Hiding-exposure effects are absent, and the hiding-exposure formula (5.6) indeed reduces to $\xi_{1}=1$. In this uniform case, sorting phenomena clearly cannot take place.

The sand wave evolves nearly identically to the simulation in Section 5.4.2, i.e. leading to a similar sand wave shape. Comparing the bimodal case presented in Section 5.4.2 to this result, the heterogeneity of the sediment apparently does not affect the shape of the sand wave.

\subsubsection{Sensitivity to Sediment Composition}

From additional simulations not further detailed here, we report the following observations (details in Wientjes, 2006).

1. Reducing the difference between the grain sizes, while keeping the mean $D_{m}$ constant, slows down the sorting process. However, the qualitative behaviour is the same as before in Section 5.4.2.

2. Taking larger grain sizes, while keeping the difference $D_{\text {coa }}-D_{\text {fi }}$ constant, produces the same qualitative tendency as the reference run in Section 5.4.2, with coarse grains accumulating at the crest. The initial redistribution of fine and coarse grains, however, may show a fining of the crest when very large grain sizes are used (i.e. 900 and $1100 \mu \mathrm{m}$ ).

3. Simulations without hiding-exposure, i.e. taking $\xi_{j}=1$, show the same qualitative behaviour, but more pronounced and quicker coarsening of the sand wave crest.

4. Increasing the value of the active layer thickness slows down the rearrangement of coarse and fine grains over the sand wave. If the active layer is taken too small, i.e. when there is more transport in a time step than available in the active layer, the chance that the simulation collapses is large.

5. Changing the volume fractions in both the active layer (the initial situation) and the substrate does not lead to large differences. The fractions in the trough stay close to the substrate fractions during the sand wave evolution.

6. Finally, when adopting three sediment classes $(N=3)$ instead of two, the qualitative picture is similar. Coarse grains accumulate at the crest, where the concentration of intermediate and fine grains becomes zero.

\subsubsection{Sensitivity to Environment}

To test the robustness of the results of Section 5.4.2-5.4.4, simulations are carried out under different hydrodynamic conditions. Both the flow velocity and the water depth are varied, see Table 5.2. Changing these parameters significantly changes both the sand wave height and the preferred sand wave length. Figure 5.5 shows the grain size distribution and the sand wave shape at two different 
Table 5.2: Parameter values for the runs where the flow velocity and water depth was varied. Run (A) is the reference run from Section 5.4.2. See also Figure 5.5

\begin{tabular}{cccccc} 
run & $\begin{array}{c}H_{0} \\
{[\mathrm{~m}]}\end{array}$ & $\begin{array}{c}U \\
{[\mathrm{~m} / \mathrm{s}]}\end{array}$ & $\begin{array}{c}L_{\mathrm{sw}} \\
{[\mathrm{m}]}\end{array}$ & $\begin{array}{c}H_{\mathrm{sw}} \\
{[\mathrm{m}]}\end{array}$ & $\begin{array}{c}\mathrm{GR}^{*} \\
{[-]}\end{array}$ \\
\hline (A) & 30 & 1.0 & 650 & 23 & $1.6 \mathrm{e}-8$ \\
$(\mathrm{~B})$ & 30 & 0.5 & 520 & 30 & $5.9 \mathrm{e}-9$ \\
$(\mathrm{C})$ & 30 & 1.5 & 750 & 20 & $2.8 \mathrm{e}-8$ \\
(D) & 15 & 1.0 & 570 & 21 & $3.9 \mathrm{e}-8$ \\
(E) & 40 & 1.0 & 770 & 28 & $9.9 \mathrm{e}-9$ \\
\hline
\end{tabular}

time steps for the 4 different situations. For all cases the grain size distribution is shown after 5 years. In all cases the grain size distribution in the trough is still equal to the distribution in the substrate. On the crest and slopes the distribution has changed. The changes are largest in shallow water or with high flow velocities. The crest and slopes show opposite grain size distributions, with in two cases coarsening of the crest and finer sediment on the slopes and in two cases the opposite distribution. When the sand wave growth continues, the flanks become finer and start fluctuating towards the end of the simulation, which is possibly a numerical artifact. This finally results in the collapse of the simulations. In one case (flow velocity $1.5 \mathrm{~m} / \mathrm{s}$ ) the model was unable to simulate longer than 6 years. For the other three cases the grain size distribution (and the corresponding sand wave profile) is shown close to the final state, in all cases showing a coarsening of the crest. For a water depth of $15 \mathrm{~m}$ the trough coarsens as well in time and at the crest $F_{\text {coa }}$ stays smaller than one, also towards the end of the simulation. In the other two cases (Figure 5.5a and d) the sediment in the trough becomes fine and the coarse fractions becomes 1 at the crest. Simulations with homogeneous sediment for the runs (A)-(E) show that the heterogeneous sediment has no significant effect on the sand wave characteristics.

\subsection{Discussion}

\subsubsection{Grain Sorting in the Model Results}

The inclusion of non-uniform sediment in the numerical sand wave code by Van den Berg and Van Damme (2006) leads to sorting patterns over a (growing) sand wave. Qualitatively, the occurrence of the sorting pattern in the model results is caused by the fractional transport of different grain size classes; see the transport formula (5.5). The quantitative properties of the sorting process depend on several elements: the active layer thickness $\delta$, the hiding-exposure mechanism and the sediment composition (to be discussed below in Section 5.5.2).

In the simulations, we distinguish two subsequent redistribution processes of coarse and fine grains. As the sand wave grows, coarse grains accumulate at the crest where $F_{\text {coa }} \rightarrow 1$ and where the finer grains completely disappear: $F_{\text {fi }} \downarrow 0$. Furthermore, as the trough gets deeper over time, sediment from the substrate enters the active layer. This explains why, during large parts of the simulations, 

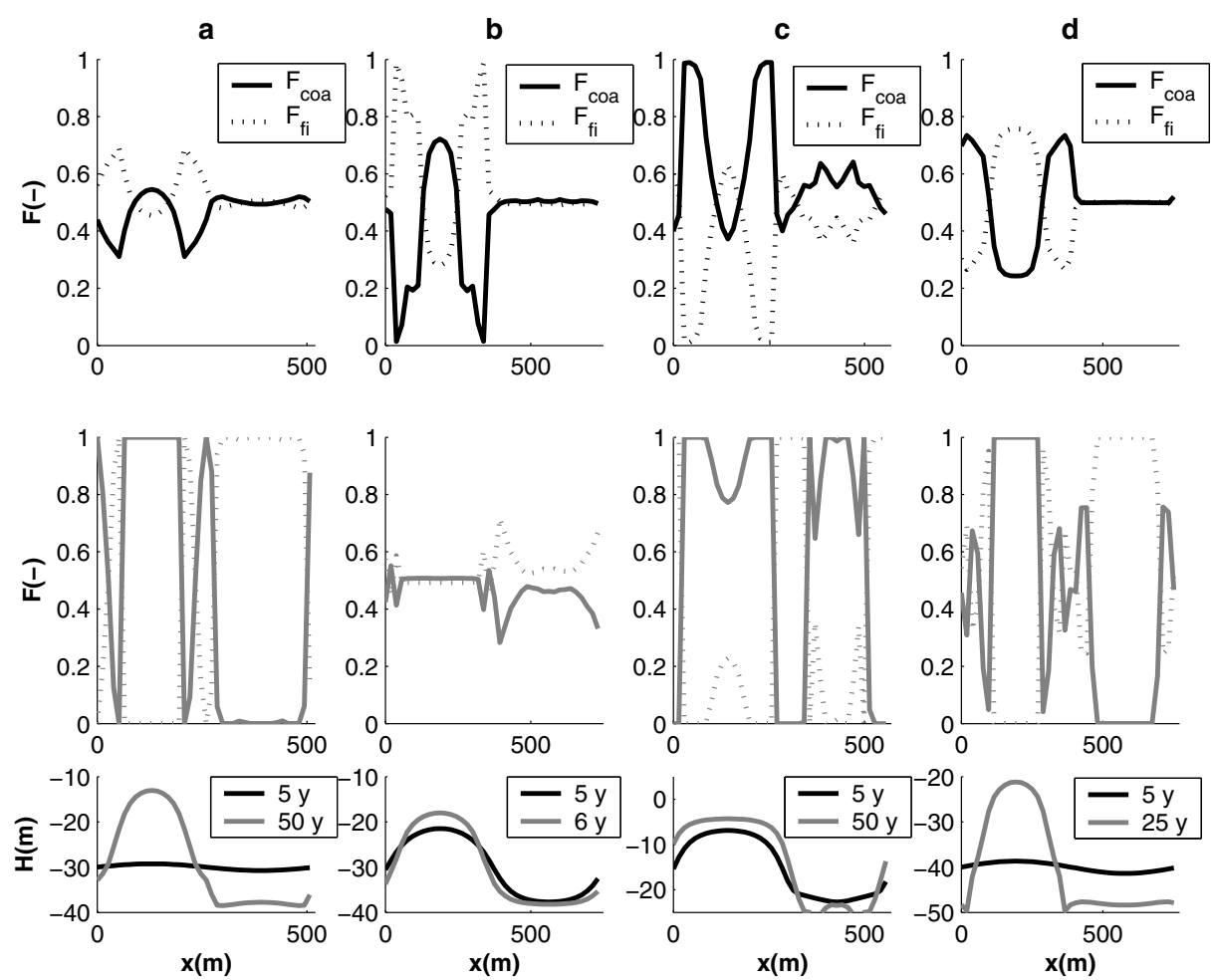

Figure 5.5: Evolution of the coarse and fine grain fraction in the active layer (top and middle) as well as the cross-sectional sand wave profile (bottom). All quantities are plotted against the spatial coordinate $x$, at different times. Different environmental situations, see also Table 5.2: (a) run B: lower flow velocity than in Figure 5.4, (b) run C: higher flow velocity, (c) run D: shallower water, (d) run E: deeper water. Note: $F_{\text {fi }}=1-F_{\text {coa }}$.

the sediment composition in the active layer in the trough is identical to that of the substrate. However, when the tidal sand wave has nearly reached a final shape, the erosion-induced vertical exchange decreases. The simulations then display a second redistribution process, associated with the fractional sediment transport over a trough that no longer deepens and leading, in most cases, to an increase in the volume fraction of fine grains in the active layer in the trough.

An unfavourable property is the collapse of the simulations when this second redistribution process has started. This means that, with the present model results, we cannot investigate the grain size distribution over tidal sand waves in a final morphodynamic equilibrium. In fact, the existence of such an equilibrium state is not guaranteed.

Crucial in the modelling approach is that the wavelength $L$ of the sand wave is chosen such that the initial sand wave growth is largest ('fastest growing mode', see Section 5.4.1). As it turns out, the value of the preferred wavelength 
$L$ is hardly affected by the inclusion of a bimodal mixture. Only with large differences in grain sizes (that we consider unrealistic in view of the observations reported in Section 5.2), the preferred wavelength $L$ may slightly shift to a different value. Also the shape and height of the sand wave are hardly affected by the change from uniform to non-uniform sediment.

As shown in earlier studies (e.g. Chapter 2), model runs with varying hydrodynamic conditions (Section 5.4.5) show that both the water depth and the flow velocity significantly affect the sand wave shape (both preferred length and final height). This study has shown that, they also affect the process of grain size sorting. Firstly, increasing the flow velocity or decreasing the water depth results in quicker sorting, as the overall sediment transport increases. Secondly, the distribution of grain sizes differs with changing hydrodynamic conditions. After 5 years, the crest coarsens and the slopes contain finer sediment for both the shallow and the deep water model runs. In the other cases the opposite happens. This agrees with findings of Van Oyen and Blondeaux (2009), who found that in the linear sand wave regime (strictly speaking, for sand wave heights that are infinitesimally small) both a coarsening and fining of the crest can occur. Still, when time continues and the sand waves grow larger, the crest coarsens in all cases. In the trough the sediment distribution becomes finer, except for the shallow water case. This might be caused by the fact that in shallow water the trough is still shallow compared to the other sand wave cases. The flow conditions would then still be too rough for the fine sediment to stay at the surface of the bed.

Unfortunately due to the numerical instability around the final state, it is difficult to draw more conclusions from the long term results as the effects due to the hydrodynamic conditions and due to the numerical artifacts are difficult to separate. Further research is needed to solve this problem.

\subsubsection{Active Layer Thickness, Hiding-Exposure and Bimodal Mix- ture}

The value of the active layer thickness $\delta$ affects the time scale of the sorting process. This result can be understood by combining equations (5.2) and (5.4) into

$$
\frac{\partial F_{j}}{\partial t}=\frac{1}{\delta(1-p)}\left[F_{\text {vert }, j} \frac{\partial\left\langle q_{\text {tot }}\right\rangle}{\partial x}-\frac{\partial\left\langle q_{j}\right\rangle}{\partial x}\right] .
$$

The evolution of the volume fraction $\partial F_{j} / \partial t$ is thus proportional to $\delta^{-1}$, explaining why a larger $\delta$ slows down the sorting process (and why a smaller $\delta$ speeds up this process). The choice of the actual active layer thickness is rather arbitrary (Blom and Parker, 2004). As the active layer consists of sediment that is directly available for the transport, it is often argued to be only a few grain sizes thick. However, if small scale bed forms such as ripples exist, the active layer thickness can be related to the ripple height (e.g. a few centimetres). From a more empirical point of view, observations of Passchier and Kleinhans (2005) show the thickness of the structureless (well mixed) active top layer of the bed. In all the three studied areas in Passchier and Kleinhans (2005) sand waves 
occur with various shapes. The structureless active layer shows seasonal variation, being smallest in June (the class of 0-9cm occurs most often) and larger in March and September (structureless layer up to larger than $19 \mathrm{~cm}$ ). From this we can assume that an active layer thickness of approximately $2-20 \mathrm{~cm}$ is a reasonable estimate in a sand wave environment. We have chosen the active layer thickness equal to $2 \mathrm{~cm}$.

Note that, in the sand wave model, both the sand wave growth and the grain size sorting depend on time. Therefore, the chosen value of the active layer thickness also defines how the sand wave evolution affects the sorting process. The smaller the active layer thickness, the larger is the effect of changes in the bed profile due to the sand wave evolution. The effect of this possible coupling of timescales is not investigated in this chapter.

The simulations without the hiding-exposure correction display a quicker evolution of the volume fractions. Indeed, as can be seen from equations (5.5) and (5.6) in Section 5.3.4, hiding-exposure reduces the difference between the critical shear stresses of the two fractions.

In this study, we have considered a bimodal mixture, which is in fact the most straightforward way of introducing heterogeneity to the sediment. Further increasing the complexity of the sediment mixture (e.g. considering a trimodal mixture) does not introduce new elements to the results. We therefore feel that the main qualitative properties of the sand wave model for non-uniform sediment are already captured when considering bimodal sediment.

\subsubsection{Comparison to Observations}

In comparison to the observations, we first make the following remarks. Realistic grain sizes of the bimodal sediment mixture (see Table 5.1) were chosen in the model runs. Moreover, the wavelength selected by the modelling approach is of the order of observed wavelengths. The model results, however, give sand wave heights that exceed the empirical values (Table 5.1). This discrepancy can have several causes: the flow conditions in the model not matching the local conditions at the five sites in the North Sea, the lacking of some physical processes like wind waves, and the uncertainties in the hydrodynamic and sediment transport modules. Furthermore, it should be noted that the model runs did not reach a morphodynamic equilibrium state, which is assumed to be the case in the North Sea, since sand wave shape and dimensions change only little in time (van Dijk et al., 2006).

The model results qualitatively agree with sorting patterns over sand waves in the North Sea, both showing a trend of coarser grains accumulating at the crests. Although the empirical sorting trend, as summarised in Section 5.2.3, is more subtle, the fraction of fines $(D<63 \mu \mathrm{m})$ is completely absent in bed samples taken at the sand wave crests.

Although increasing the number of grain size classes $N$ does not change the qualitative properties of the model results, we believe that the use of a more realistic grain size distribution would allow a more detailed comparison between model results and observations. Indeed, when considering a larger number of 
classes, quantities such as the median grain size $\left(D_{50}\right)$ and the sorting ratio $\left(D_{60} / D_{10}\right)$ can be modelled in a meaningful way.

Model runs were done for symmetric tidal flow conditions, containing the dominant M2-tidal constituent only. As a result, the modelled sand waves are also symmetric and they do not migrate. To better reproduce the asymmetric and migrating sand waves (e.g., see Figure 1c), a more detailed representation of the site-specific tidal characteristics is required, including higher harmonics (such as an M4-component) and residual flow (M0). This asymmetry in the forcing is also likely to introduce an asymmetry in the modelled sorting patterns.

\subsection{Conclusions}

We have extended an existing sand wave simulation code to account for the presence and transport of non-uniform sediment. To this end, we have adopted the active layer approach after Hirano (1971) and considered a fractional sediment transport module, involving hiding-exposure effects according to Egiazaroff (1965). The model results, simulating a growing sand wave with a bimodal sediment mixture, indicate that coarse grains accumulate at the crest, whereas the trough remains mixed with both coarse and fine grains during the sand wave evolution. Towards the final state the trough becomes finer in most situations. The result of a coarsening crest is robust under various flow velocities and water depths. Still, the initial behaviour can vary from a coarsening of the crest (and finer sediment on the slopes) to a coarsening of the slopes (and finer sediment on the crest). The heterogeneous sediment has no significant effect on the sand wave characteristics such as length and height. Fractional transport turns out to explain the qualitative sorting trend in the results. The model results show qualitative agreement with detailed observations from various sites in the North Sea.

Acknowledgements This work originates from I.G.M. Wientjes' master's thesis Civil Engineering \& Management, University of Twente. Data were collected and corrected in collaboration with the Directorate North Sea, Dutch Public Works and Water Management (DNZ-RWS). 


\section{Chapter 6}

\section{Discussion}

In the previous chapters various processes are included in the sand wave model to investigate their effect on sand wave characteristics. This discussion aims at placing the results in a broader view. Section 6.1 will discuss how the Sand Wave Code (SWC) compares with other model approaches that are used for sand wave morphodynamics. Subsequently, the SWC results are discussed in Section 6.2. Special attention is paid to the possible effects of combined physical processes and on the restrictions of the SWC.

\subsection{Model Approach}

In this thesis, an idealized non-linear model is used to study the effect of various conditions on sand waves. Of course, there are other models that can be used to study sand waves. This section aims at discussing some possibilities of other modelling approaches that reveal information on sand waves. The focus is on how the different model approaches can be used to answer different questions, and why the SWC was the most appropriate model to answer the research questions in this thesis.

\subsubsection{Linear versus Non-Linear Modelling}

Linear and non-linear modelling deal with the sand wave problem from a different angle, but based on the same background of stability analysis. It depends on the research question what model approach is most appropriate. In some cases the approaches can be used in parallel and can validate each other.

Linear modelling of sand waves holds only as long as disturbances are very small. In the sand wave case this means that the amplitude of bed forms should be (infinitesimally) small. Although this is not valid for field observations, still the linear modelling adds to our knowledge of sand waves. Due to its linearity the problem can often be solved semi-analytically. This results in insight in the initial reaction of sand waves on processes or parameters. Linear studies can predict, for example, a preferred sand wave length, the sand wave orientation towards the flow direction and the initial migration rate of sand waves. However, according to the final sand wave shape, such as its height and asymmetry, the linear modelling can not give information. Also, although initial migration and sediment sorting can be predicted by the linear model, non-linear effects on the longer term (i.e. over fully grown sand waves) can not be predicted. 
Although semi-analytical solutions are possible in the linear regime, often use is made of numerical modelling. For example Blondeaux and Vittori (2005a,b) describe a linear morphodynamic model to study among other features, sand waves. The model can be used in three dimensions, various physical processes are implemented in detail. Still the effects of processes on sand wave characteristics remain to be explained.

In the non-linear regime, solving problems semi-analytically becomes more complicated and numerical models are used. Including the non-linear regime enables us to investigate the final state where the fully grown sand wave is in equilibrium with the flow. The results can be compared more directly with field observations. The effect of physical processes can be studied both in the linear and the non-linear regime.

For the presented study our interest was on the variation in sand wave morphology and dynamics on the long term, including the non-linear sand wave height and asymmetry. The SWC is able to simulate the sand wave morphodynamics up to its final state with low computational costs. It includes both the linear and non-linear effects, which makes it a powerful tool.

\subsubsection{Data Based versus Process Based Modelling}

The SWC is especially useful to gain understanding in the effect of (separate) processes on sand waves. Field observations have the drawback, in this sense, that the influence of different processes can hardly be separated. The sand waves are a result from a long history of events.

Due to the characteristics of the tide and feedback mechanism with the sand waves, scaled modelling in laboratories is not possible. The time scale of the tidal wave is difficult to scale down so much as to fit in a flume, without loosing its long wave characteristics and effect on the sand waves (e.g. the Froude and Reynolds number require different scaling of the velocity, and flow separation often occurs when the time and length scale are reduced). Also the oscillating character of the flow is often a drawback as flumes produce often only waves from one side.

Recent availability of long term and accurate field data greatly enhances the possibility to study sand waves from field measurements. For example Buijsman and Ridderinkhof (2008a,b) describe migration and shape changes in the Marsdiep sand waves on the basis of a long term dataset. Dorst et al. (2009) use a large data set of a sand wave field combined with statistical methods to describe changes in the sand wave field (growth, migration). Also e.g. Knaapen and Hulscher (2002); Morelissen et al. (2003); Knaapen (2005) combine data and modelling to predict a sand wave characteristic (growth or migration).

Although these methods are not directly investigating the physical processes behind the sand waves, using datasets is a powerful way to describe sand wave behaviour. Advantage is that the databased modelling starts from the available data and thus with a correct description of the sand waves. Besides, the model of Dorst et al. (2009) also incorporates the observed variation and so a range of possible values. The results of the SWC are less easy to compare with ob- 
served features. For example the SWC often overpredicts the sand waves height compared to the observed sand waves. However, we can hypothesize that this is the maximum height or that the final stage that is not reached, e.g., due to not incorporated processes that lower the sand waves. The inclusion of physical processes can then test this hypothesis. With the data based modelling this link with physical processes is only possible indirectly. Observed changes in the sand waves can be compared with other data sets available at that specific location, e.g., surface wave conditions. Statistical comparison can then lead to insight in possible surface wave impact (for example if periods of large surface waves coincide with a decrease in sand wave height).

Disadvantages of the data-based-models are that the models need an accurate and long term (several years) data set and that the results are not easy to generalize to other locations. A data based tool that overcomes this problem is presented by Knaapen (2005). He presents a migration predictor, which predicts migration based on the shape of sand waves. This reduces the need for data to a one moment observation, as no long term data is needed.

The recent availability of long term and accurate data sets increase the possibilities to verify model results with field data. To enable verification of the effects of specific processes on sand waves more directly with measurements, it would be interesting to see, for example, the effect of individual storms on sand waves (i.e. measuring before and after a storm). Also further increasing the available data on grain size distribution over the sand waves and the available sediment in the water column will help verifying the model results.

\subsubsection{Idealized versus Full/Complex Modelling}

The SWC is an idealized process-based model. Process-based modelling aims at describing the important physical processes in terms of differential equations. Idealized modelling assumes a simple geometry, input and boundary conditions, to study morphological features at a morphodynamic time scale, i.e decades to centuries. In contrast, full process-based modelling includes different processes (e.g. wind- and wave-driven currents, density gradients, sediment transport) within broad classes of problems over different temporal and spatial scales, and is able to deal with complex, site specific, geometries (e.g. the observed bathymetry).

Morphodynamic modelling on a long term scale is up till now only done with idealized models. Although complex models include the required processes there are still some drawbacks when using them for modelling sand wave evolution. To investigate the present possibilities, test simulations with Delft3D (Appendix 6.2.3) were carried out. Sand waves are described in a 2DV approach in Delft3D.

The first drawback of complex modelling is the long computational time. For modelling sand wave evolution, most time consuming is the fact that the grid over the sand wave needs to be fine enough (i.e. approximately 30 points over a sand wave) and the flow field in the vertical needs to be taken into account (i.e. a $2 \mathrm{DH}$ approach is not enough). As the small residual circulation over the sand wave within a tidal cycle is crucial, also the flow can not be directly averaged 

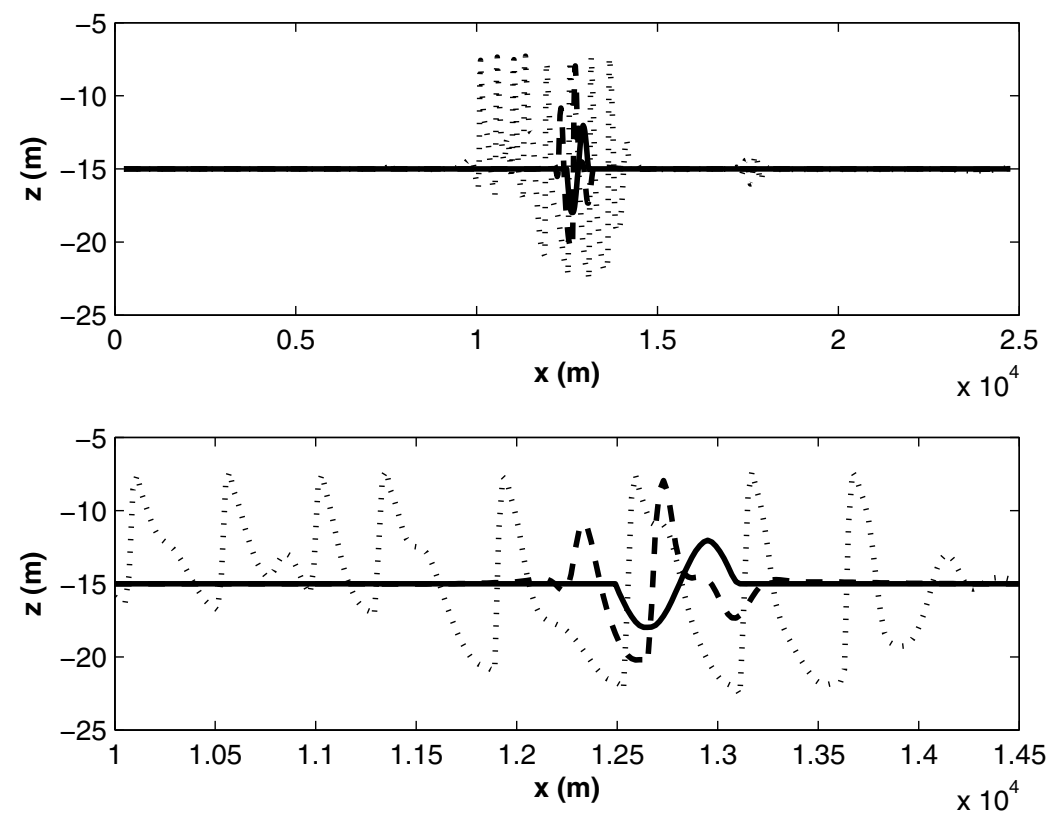

Figure 6.1: Simulation of sand wave growth in Delft3D, in a water depth of $15 \mathrm{~m}$ and a M2 tidal current with a maximum of $1 \mathrm{~m} / \mathrm{s}$. This side view shows the sand wave at different times in the evolution growing from one sand wave to a sand wave field. The top panel shows the whole model domain, with a flat bed at the sides to overcome boundary effects. The lower panel shows the sand wave area in more detail. The solid line represents the initial bed, the dashed and dotted line the bed development in time.

over the tide. The result is that simulating for decades requires months of computational time. In comparison, for the same study case, the idealized SWC only takes in the order of minutes to tens of minutes. Morphological time stepping in Delft3D reduces the computational time, but can only be used up to a certain rate, after which it affects the results too much. This is especially the case as the feedback mechanism depends on small variations. Large morphodynamic time stepping results in missing the final state and exploding results.

The second drawback is the numerical diffusion. As Delft3D is used for a large range of problems, its numerical approach is robust. However, the used numerical scheme also includes numerical diffusion that results in damping sand waves when the amplitude is small. Although part of this diffusion can be turned off, still for amplitudes less than a metre, Delft3D predicts no growth at all. If the sand wave amplitude is large enough to disturb the flow, Delft3D does produce growing sand waves (Figure 6.1). No in depth comparison between the Delft3D results and the Sand Wave Code results is carried out.

As no periodic boundary conditions are included yet, a long domain is 
needed. Starting with one sand wave, growth occurs and in time more sand waves are formed around the initial sand wave (Figure 6.1). As the sand waves grow towards the side areas where the grid spacing is larger, the model reliability decreases. The results are then depending on the grid spacing instead of on the physical processes. Therefore, the simulations are ended when the sand waves reach the model boundaries. In some cases disturbances occur at the boundaries such that, after some time, the sand wave field is affected by the boundaries and the simulations have to be ended. Including periodic boundary conditions could overcome these problems and also reduce the computational time as the domain can be smaller.

Although the discussed problems were found using Delft3D, they are expected to be generic for most complex full process based models. These models can differ in model set up or used background, but in general the computational time will be much larger than for the idealized modelling and numerical diffusion and boundary problems are expected.

In summary, at the moment it is possible to produce growing sand waves with complex process based models like Delft3D, but at much higher costs and with more uncertainties than in the idealized SWC. To use complex models seems not realistic yet due to the extreme computational time and the problems with numerical diffusion and boundary effects. It is possible to use complex models for short term predictions on already fully grown sand waves. This requires available field data as input and can not give information about the long term morphodynamic evolution. However, as complex models are mostly not tested on the effects of morphodynamic feedback mechanisms, further research is necessary to verify the results. This can be done by comparison with idealized models or long term datasets. Such an approach is used by Brière (2006). He studied sand banks and used an idealized model for the long term predictions and Delft3D for the short term predictions. Tonnon et al. (2007) used Delft3D to investigate a sand wave like feature over a timescale of 15 years. Overall, we conclude that idealized models are still necessary for investigating the effect of specific processes, long term predictions and verifying complex model results.

\subsection{SWC Results and Further}

\subsubsection{General Results}

Without the processes added in the Chapters $3-5$, the model already showed to be able to predict sand wave characteristics well (Chapter 2). Shape, height and length of the predicted sand waves were in most cases well in range with observed values. In the Golden Gate study area, the inclusion of a residual current turned out to be essential. The largest model difficulty was predicting small sand waves in the relatively shallow water. Also in other chapters it is shown that changes in the flow field are most important for the sand wave shape and behaviour. Both a residual current and surface waves change the model results significantly to more realistic values. Grain size and sediment transport mechanisms also affect the sand waves but to a smaller extent. 
In general the model often overpredicts the sand wave amplitude. If the investigated processes are taken into account this overprediction is reduced. This leads to the hypothesis that the basic, symmetric model predicts maximum sand wave heights. In the field, sand waves are lower due to other physical processes. These processes cause instabilities leading to a disturbance of the equilibrium situation and with that lowering the sand waves. For example in the Golden Gate case study the asymmetric current causes this disturbance of the flow field, lowering the sand waves significantly. Probably the inclusion of other processes will also improve the shallow water results in the Golden Gate area. The combination of various processes or specific events is expected to give further understanding and better predictions.

\subsubsection{Combination of Processes}

The focus in the previous chapters was on the effects of individual processes on sand waves. However, the combination of different conditions is not yet tested in detail. First reason for this is that our focus was on the separate effects of the physical processes. Including various processes at once, complicates this understanding of the individual process effects. Second reason is that to combine the different processes, the model needs more changes than the sum of the present equations. For example, when both surface waves and suspended sediment is included, the effect of surface waves on suspended sediment has to be described and modelled as well. Therefore, suspended sediment transport is only studied under calm weather conditions, while it is expected to play a role especially in combination with surface waves. And surface waves are investigated but with only bed load transport. The same holds for the combination of suspended sediment transport and sediment mixtures. The processes are expected to interact and possible change the sand wave behaviour due to non-linear interactions. This section aims at studying the effect of combinations of the studied processes.

\section{Surface Waves and Suspended Sediment}

In Chapter 3 and 4 the individual effects of surface waves and suspended sediment are investigated. The results show that both processes lower the sand waves and increase the possible migration rate. Suspended sediment also shortens the sand wave length and increases the growth rate. For surface waves the effect on sand wave length was not investigated as, due to their temporary character, they are not expected to affect the slowly changing sand wave length. Both processes change the sand wave shape differently. Suspended sediment decreases the crest/trough length ratio (the troughs become longer) and reduces the total sand wave height. With the inclusion of surface waves this ratio increases for both the sand wave length and height (causing flatter and broader crests).

Technically, if we want to simulate both processes in the sand wave model, both the tidal current and the surface waves need to be included in the advection diffusion equation. Besides the possible differences between their behaviour 
on suspended sediment, also their difference in bottom boundary layer thickness might be important. The thinner wave boundary layer can increase the suspended sediment due to surface waves.

The effect of the combination of the two processes is not straightforward. Suspended sediment is expected to increase under surface waves, possibly increasing the effects of both processes. As surface waves reach the sand wave crests easier than the troughs, sediment might be suspended more from the crests, possibly resulting in a lowering of the sand waves and filling of the troughs. As both processes individually reduce the sand wave height, lower sand waves are expected. Still due to non-linear effects, a combination of both processes may have less or different effects. More difficult are the shape changes, as the processes have opposite effects on the sand wave shapes. As the surface waves in general affect the sand waves more, their effects might be the final result, slightly decreased by the suspended sediment effect.

\section{Suspended Sediment and Grain Size Mixtures}

As presented in Chapter 4 suspended sediment can affect sand wave morphodynamics significantly under calm weather conditions. Most important effects were a decrease in the crest/trough length ratio and a lowering of the total sand wave height. Smaller grains slightly increased the suspended sediment effect. Chapter 5 described the grain size sorting over sand waves and showed that, although sorting occurs, the sand wave shape is not affected by this sorting.

Combining a grain size mixture and suspended sediment transport over sand waves can change the results in either direction. Smaller grains are transported easier in suspension than larger grains. The result would be an increased sorting process as (1) the differences in transport rate between grains become bigger and (2) the suspended sediment transport would transport small grains away from the crest, thus enhancing the existing trend of coarsening towards the crest.

The sorting process on the other hand can decrease the suspended sediment transport over sand waves. Where the suspended sediment transport would be largest, the smaller grains would disappear. Due to the larger grain sizes the suspended sediment transport would decrease, thus leading to a balance where suspended sediment transport is more equal over the sand wave shape. The sand wave shape would be closer to the bed load only shape, i.e. with a slightly longer sand wave length, larger amplitudes and milder slopes.

Finally with grain size mixtures it is interesting to mention the occurrence of armour layers in the sea bed. Observations show that in the sea bottom sediment is not well mixed but often consist of layers of different sediment and erodability (Trentesaux et al., 1999; Le Bot and Trentesaux, 2004). The existence of non erodible layers in the sediment results in sand waves that grow and migrate on top of such a layer. Tuijnder et al. (2009) showed with flume experiments than the amount of sediment can strongly effect the dimensions and regularity of sand dunes. It can be expected that sand waves will be affected similarly by partial transport conditions. Further investigation of coarse layers and its effect on sand waves would be interesting as it can possibly have more influence than 
the small variations in grain size that occur on the sand wave surface.

\subsubsection{Model Drawbacks}

The model used in this thesis has shown to be helpful when studying the influence of various conditions on sand waves. However, in some conditions the model results were unexpected and the validity of the model could be questioned. In this section we discuss some of the restrictions and unexpected results of the model.

\section{Restrictions}

Due to the model set up and the numerical set up, the SWC is meant specifically to study sand wave evolution on a long time scale.

The shallow water approximation restricts the SWC to cases where the length of the domain (i.e. the sand wave length) is larger than the water depth. In few cases the predicted sand wave length was smaller than the water depth, i.e for suspended sediment transport only and for strong asymmetric flow conditions. In that cases the SWC should not be used.

Also in extreme deep water (Golden Gate, water depth of $70 \mathrm{~m}$, suspended sediment, water depth of $40 \mathrm{~m}$ ) the model sometimes showed unstable results when searching for the FGM. This might be caused by the limited possibility of sand waves to grow in such conditions. However, it is also possible that the model set up is incapable of describing such deep water conditions correctly. This could maybe be improved by adjusting the eddy viscosity and the slip parameter.

In most of the presented results in this thesis, the model domain was fixed to the length of the linear defined FGM. There are several indicators for the assumption that sand waves are only weakly non-linear: their amplitude is generally smaller than $20 \%$ of the water depth and the predicted fastest growing wave length (growth in height) is close to the observed wave length. Assuming weak non-linearity, the dominating wavelength for linear bedforms will be close to the one dominating in the non-linear regime, i.e. for full grown sand waves. Subsequently, the fastest growing mode indicates the dominant sand wavelength that is found to be close to the dominating one in reality for weakly non-linear systems (Dodd et al., 2003). However the model is well capable of dealing with much larger domains. These can be used to study for example sand wave interaction or variation within a transect (e.g. Section 2.4.4). A disadvantage of this long domain simulations is that the simulations finally evolve to one large bedform, of the length of the model domain. This is caused by the fact the large waves are not totally damped but show a small but positive growth rate. In a long domain they will, in the long term overtake the smaller sand waves. At this moment the only way to overcome this is to reduce the model domain to the length of the FGM.

If the bed slope exceeds 14 degrees, flow separation can occur in the field. Although most sand waves do not reach this angle by far, under asymmetric strong tidal conditions they can reach this bed slope (See Chapter 2). Flow 
separation and the corresponding changes in the sediment transport are not incorporated in the SWC as hydrostatic pressure is assumed. Recent detailed measurements combined with modelling suggest the occurrence of a combined situation of both rest circulation cells and flow separation areas (Winter et al., 2008; Winter, 2008). Using the same model set up as the SWC in a river environment, Paarlberg et al. (2007) parameterized the flow separation zone and included this in river dune simulations. It would be interesting to implement this in our oscillating sand wave simulations to investigate the effects of flow separation. The similar basis of both models gives confidence in the feasibility of such a combined model.

\section{Model Oddities}

As the SWC is a deterministic model, it is meant to give one single solution to a specific problem. For example, the growth towards a final state should be independent of the numerical set up or initial conditions and lead to a final (stable) equilibrium solution (Figure 6.2 black line). Under certain conditions, however, the model simulates rather fluctuating or even chaotic behaviour in the sand wave height, such that a final equilibrium was oscillating or not reached (Figure 6.2 grey lines).

One cause of these fluctuations is the time stepping. The model can be used with either a user fixed time step or with a varying time step chosen by the model. In the last case the time step is decreased when the sand wave grows quick, to decrease the inaccuracy in the solution. When the sand wave growth slows down, the time step is increased again. The model uses a Newton iterator to find the flow solution for the next time step. Depending on the difference in the flow field between the present and next step, the time step can be changed. This way, the computational time and accuracy is optimized. However, in some cases the simulation gets stuck. The model can not find the solution for the next time step with the prescribed accuracy and continues reducing the time step down to zero. The result is that the model seizes up at a certain time and can not continue to a equilibrium. This problem is overcome by fixing the time step or reset the time step when it gets too small. However the effect can be that the solution starts to oscillate or even becomes unpredictable.

Another cause of the oscillations can be an physical one. In that case the found oscillations should be found in observations as well, representing the reality better than the assumptions of a static stability.

Small oscillations sometimes occur due to sand wave migration through the model domain. In this case the sand wave height changes slightly when migrating from one grid point to another, due to the discrete space between the horizontal grid points. Simulations with different grid spacing confirmed this and showed that this has no quantitative effect on the final equilibrium state.

In this thesis the SWC is used mainly with a fixed domain of one sand wave length. However, the numerical set up is such that larger domains can be simulated without a large increase of computational time (e.g. Van den Berg 


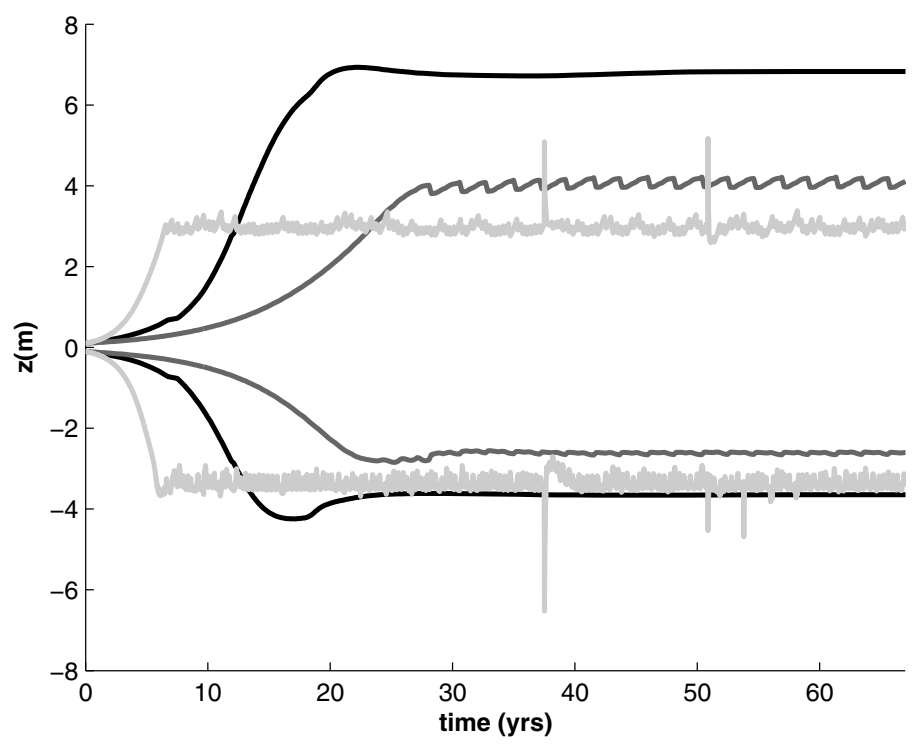

Figure 6.2: Growth of the sand wave crest and trough in time for three different set ups. The model finds either a stable, a fluctuating or a chaotic solution.

and Van Damme, 2006). Although this can be used to study the growth and interaction between sand waves, the model evolves in the end to an unrealistic state of one large bed form covering the whole domain. This can be explained by the fact that large bed forms have small but positive growth rates. although per definition smaller than the growth rate of the FGM, in time the larger bed forms grow and overtake the smaller ones, when the domain is large enough to let them grow. In case of migrating sand waves, smaller sand waves are overtaken even faster. Solutions to overcome this problem are e.g. reducing the domain length to one sand wave length, or impose a maximal length of the slopes after which a splitting process occurs which reduces the sand wave length (Dohmen-Janssen et al., 2008). Still these solutions are not a physical explanation or solution to the problem. Note that other models studying sand waves or similar morphodynamic features often do not reach this state as they either simulate only a short period or do not simulate the final state. 


\section{Appendix}

\section{Background on Delft3D}

The spatial discrete approach in Delft3D can be used in 2DV, 2DH and 3D. Delft3D is a full process based model, consisting of a number of integrated modules which allow the simulation of hydrodynamic flow (under the shallow-water assumption), computation of the transport of water-borne constituents (e.g. salinity and heat), short wave generation and propagation, sediment transport and morphological changes, and the modelling of ecological processes and water quality parameters (WL|Delft Hydraulics (2006); Lesser et al. (2004)).

We used Delft3D in the 2DV set up, simulating sand waves transects in the same spatial surroundings as the SWC. As the SWC, Delft3D starts from the water continuity equation, the hydrostatic flow equations under the shallow water approximation and a sediment transport equation. The bed elevation is updated each time step, changes are calculated using the calculated sediment transport gradients. For equations and further details, we refer to e.g. $W L \mid D e l f t$ Hydraulics (2006); Lesser et al. (2004).

At the seabed and sea surface, vertical velocities are zero and friction is calculated from the shear stresses due to currents and waves. At the vertical boundaries, water level is prescribed on one side and the flow velocity on the other side.

In the vertical direction boundary fitting $\sigma$-coordinates are used. The number of layers is constant over the modelled area, the layer thicknesses varies to account for the changing water depth. The layer thickness is non-uniform distributed to encounter more resolution in the area of interest (i.e close to the bed or close to the water surface).

We use Van Rijn's bed load transport equation following Van Rijn and Walstra (2003), but also other equations are tested. Instead of periodic boundaries, as used in the Sand Wave Code, a large flat bed domain is simulated on both sides of the sand wave area. The tidal forcing is simulated as an tidal current, including the spring-neap cycle.

A morphological factor is used to reduce the long computational time (Roelvink (2006)). In this approach, the calculations per time step within the tide are multiplied with the morphological factor, up to 100-1000, but if for example waves are present 1-50 is more likely. This lengthening of the tide increases the calculated morphological time within one tide calculation. Due to the feed back mechanism in the sand wave system, high values of the morphological factor disturbs the results. Factors higher that approximately 100 can not be used.

Delft3D is not yet used for long term predictions of large offshore morphological features, nor have sand waves been simulated. Brière (2006) investigated the effect of sand mining on sand banks using Delft3D. Sand banks have wavelengths in the order of kilometers and heights of tens of meters (Dyer and Huntley (1999)). Delft3D was used for the short term flow and sediment transport. For the longer term, i.e. decades to centuries, Delft3D was combined with an idealized sand bank model. Following Brière (2006) we use a central discretization method for the bed load sediment transport component, instead 
of the upwind default scheme. This last one was found to produce numerical diffusion damping the bed forms.

Also suspended sediment is turned of, and short waves are not included. Viscosity is described in different ways depending on the simulations. Both a constant and the $\mathrm{k}-\epsilon$ model are tested.

The horizontal spatial discretisation in Delft3D is based on finite differences. We used a rectangular and staggered grid method, like in the SWC. 


\section{Chapter 7}

\section{Conclusion}

In this thesis the main research questions were formulated as follows:

1. To what extent do the Sand Wave Code results describe and explain observed (variation in) sand wave fields.

2. Do the following physical processes significantly contribute to the modelled sand wave characteristics and their variation, and if so, in what way and to what extent:

- suspended sediment transport (vs. bed load transport)

- wind waves (vs. tidal flow)

- variation in and sorting of different grain sizes

In this concluding chapter these questions are answered by summarizing the conclusions of the previous chapters. Subsequently some recommendations for further research are given.

\subsection{Model Predictions}

A detailed comparison between the Golden Gate sand wave field and the SWC is carried out. The results show that the SWC is able to describe the variation in the Golden Gate sand waves well. The results of the SWC compare reasonably well with the observed sand waves when both an oscillating and an residual current are taken into account. Except for one transect, where the water depth was relatively shallow, it seems enough to implement this forcing and bed load sediment transport to find the sand wave height, length and shape close to the observed values for the different locations. Current together with water depth seem to be the most important factors influencing sand wave characteristics. To model wave length, height and shape correctly it is crucial to include the local residual current.

Large domain simulations give an indication of the possible variation within a single transect. However, in this large domain simulations no final state could be established. 


\subsection{Physical Processes}

\subsubsection{Suspended Sediment}

Suspended sediment is implemented in the SWC, and its effect is investigated under calm weather conditions. It shows that suspended sediment in general (1) shortens and lowers the sand waves, (2) increases the growth and migration rate and (3) decreases the crest/trough ratio for the sand wave length and height. The qualitative effect of suspended sediment is robust under variation of the water depth and the grain size. Decreasing the grain size, increasing the current, or changing it from symmetric to asymmetric, increases the quantitative suspended sediment effects. Although the suspended sediment transport is small compared to the bed load transport, it can significantly affect the long term sand wave evolution and final shape. The predicted concentrations are reasonable when compared with observations under sand wave conditions.

\subsubsection{Surface Waves}

The results of the SWC show that surface waves can significantly influence the sand wave shape and migration. In general, surface waves lower the sand wave height and cause migration in the direction of the surface waves. The shape changes to a broader crest, milder slopes and a smaller trough. The quantitative effect depends both on the surface wave characteristics and the sand wave environment.

Though larger surface waves lower the sand waves more, due to their low frequency of occurrence the effect on sand waves is smaller than that of smaller, but more frequently occurring, surface waves. The relative importance of smaller surface waves coincides with observations that indicate that the general surface wave climate is more important than individual large storms.

The effect of surface waves increases for decreasing tidal currents and decreasing water depths. The effect of surface waves is not linear with the surface wave height. In shallow water small surface waves have relatively more effect, causing a big decrease in sand wave height. The lowering due to surface waves with a larger wave height is relatively smaller. In deep water the opposite effect is predicted. On average surface waves can cause a $20 \%$ lowering of the sand wave height and a migration rate of several metres up to tens of metres per year.

Including surface waves improves the sand wave model predictions of sand wave height and migration rate to values in range with observed sand wave values.

\subsubsection{Grain Mixtures}

Observations from the North Sea indicate a trend of coarser sediment with a higher sorting at sand wave crests. We extended the SWC to account for the presence and transport of non-uniform sediment. The extension involves an active layer as well as a fractional calculation of sediment transport, which includes 
hiding-exposure effects. Simulations of a growing sand wave for a bimodal mixture indicate a coarsening trend towards the crest. In the sand wave troughs the sediment remains mixed during the sand wave evolution and becomes finer when the sand wave growth decreases. The heterogeneous sediment has no significant effect on the sand wave height and length. The model results show qualitative agreement with observations from various sites in the North Sea.

\subsection{Recommendations}

From the previous sections we can conclude that the SWC is a powerful tool when studying sand waves at all the stages of their evolution. At the moment it is the only available tool that has proved to be able to model sand waves from their initial state up to their final shape. The model results are in range with field observations. However, as the model is idealized, it results in an average sand wave, for the given physical conditions. The model has shown to be of use when studying the effect of physical processes on sand wave morphodynamics.

The following recommendations can be given for further research on this topic.

- Combine the different physical processes that are implemented in the SWC to study their combined behaviour.

- Extend the model such that it can deal with sand waves in an estuarine environment (e.g. stronger asymmetry in current and flow seperation).

- Compare the model results with field data from different areas to test its ability to predict differences between areas.

- Combining field measurements and model results to improve knowledge in both areas. The model predictions will give insight in the important processes such that field measurements can focus on these processes. The field observations can validate the model results and help understanding what processes should be included or how well the chosen equations describe the reality. A possible way to do this might be the implementation of the model in a GIS environment (Van der Veen et al., 2006).

- The model might be extended to a three dimensional model of sand waves. Although it will be time consuming to model 3D, it might help to give insight in specific 3D sand wave behaviour, such as bifurcations.

- The code could be improved if a solution for the time stepping was found. Also the usability of the model could be improved by a clearer user interface. In that way the model can be used by both researchers and end users. 


\section{Bibliography}

Barnard, P. L., D. M. Hanes, D. M. Rubin, and R. G. Kvitek, Giant sand waves at the mouth of San Francisco Bay, Eos, 87(29), 285-286, 2006.

Barnard, P. L., J. L. Eshleman, E. L. H, and H. D. M, Coastal processes study at Ocean Beach, San Francisco, CA: summary of data collection 2004-2006, Tech. Rep. Open-File Report 2007-1217, 165pp., http://pubs.usgs.gov/of/2007//1217//, U.S. Geological Survey, 2007.

Besio, G., P. Blondeaux, M. Brocchini, and G. Vittori, Migrating sand waves, Ocean Dynamics, 53, 232-238, 2003a.

Besio, G., P. Blondeaux, and P. Frisina, A note on tidally generated sand waves, Journal of Fluid Dynamics, 485, 171-190, 2003b.

Besio, G., P. Blondeaux, M. Brocchini, and G. Vittori, On the modeling of sand wave migration, Journal of Geophysical Research, 109, C04,018, 2004.

Besio, G., P. Blondeaux, and G. Vittori, On the formation of sand banks and sand waves, Journal of Fluid Mechanics, 557, 1-27, 2006.

Besio, G., P. Blondeaux, M. Brocchini, S. J. M. H. Hulscher, D. Idier, M. A. F. Knaapen, A. A. Nemeth, P. C. Roos, and G. Vittori, The morphodynamics of tidal sand waves: A model overview, Coastal Engineering, 55, 657-670, 2008.

Bijker, R., J. Wilkens, and S. J. M. H. Hulscher, Sand waves, where and why?, in Proceedings of the eigth international offshore and polar engineering conference, vol. 2, pp. 153-158, Montreal, Canada, 1998.

Blom, A., and G. Parker, Vertical sorting and the morphodynamics of bed formdominated rivers: a modeling framework, Journal of Geophysical Research, 109(F02007, doi:10.1029/2003JF000069), 2004.

Blondeaux, P., and G. Vittori, Flow and sediment transport induced by tide propagation: 1 the flat bottom case, Journal of Geophysical Research - Oceans, 110(C07020, doi:10.1029/2004JC002532), 2005a.

Blondeaux, P., and G. Vittori, Flow and sediment transport induces by tide propagation: 2 the wavy bottom case, Journal of Geophysical Research - Oceans, $110(\mathrm{C} 08003$, doi:10.1029/2004JC002545), 2005b.

Borsje, B., M. B. de Vries, T. J. Bouma, G. Besio, S. J. M. H. Hulscher, and P. M. J. Herman, Modeling bio-geomorphological influences for offshore sandwaves, Contintal Shelf Research, accepted, 2009.

Brière, C., EUMARSAND European Marine Sand and Gravel Resources: Evaluation and Environmental Impact of Extraction. Modelling sandbank dynamics and the effects of offshore sand extraction with Delft 3D numerical model, Tech. rep., University of Twente, The Netherlands, 2006. 
Buijsman, M. C., and H. Ridderinkhof, The relation between currents and seasonal sand wave variability as observed with ferry-mounted ADCP, in PECS 2006, Astoria, OR-USA, 2006.

Buijsman, M. C., and H. Ridderinkhof, Long-term evolution of sand waves in the Marsdiep inlet i: High-resolution observations, Continental Shelf Research, doi:10.1016/j.csr.2007.10.011, 2008a.

Buijsman, M. C., and H. Ridderinkhof, Long-term evolution of sand waves in the Marsdiep inlet ii: Relation to hydrodynamics, Continental Shelf Research, doi:10.1016/j.csr.2008.02.014, 2008b.

Calvete, D., A. Falques, H. E. d. Swart, and M. Walgreen, Modelling the formation of shoreface-connected ridges on storm-dominated inner shelves, Journal of Fluid Mechanics, 441, 169-193, 2001.

Cheng, R. T., and J. W. Gartner, Tides, tidal and residual currents in San Francisco Bay, California - results and measurements, 1979-1980, Tech. Rep. Water Resources Investigations Report 84-4339, U.S. Geological Survey, 1984.

de Koning, M. F., The stochastic characteristics of geometric properties of sand wave in the North Sea, CEESM research report 2007R-004/WEM-003, University of Twente, The Netherlands, 2007.

de Leeuw, C. J., Model predictions of wave-induced sediment transport on the shoreface, Msc thesis, University of Twente, The Netherlands, 2005.

Dodd, N., P. Blondeaux, D. Calvete, H. de Swart, A. Falqués, S. J. M. H. Hulscher, G. Rózyński, and G. Vittori, Understanding coastal morphodynamics using stability methods, Journal of Coastal Research, 19(4), 849-866, 2003.

Dohmen-Janssen, C. M., J. Lansink, A. J. Paarlberg, S. J. M. H. Hulscher, and A. P. P. Termes, Modelling river dune splitting, in Marine Sandwave and River Dune Dynamics III: MARID 2008, edited by D. R. Parsons, T. Garlan, and J. L. Best, pp. 79-86, 2008.

Dorst, L. L., P. C. Roos, and S. J. M. H. Hulscher, Estimation of sand wave dynamics in the southern North Sea, in Coastal Engineering 2006. Proceedings of the 30th International Conference, 3-8 September 2006, San Diego USA, edited by J. McKee Smith, pp. 26302642, Singapore/London: World Scientific publishing Co. Ltd., 2007.

Dorst, L. L., P. C. Roos, S. J. M. H. Hulscher, and R. C. Lindenbergh, The estimation of sea floor dynamics from bathymetric surveys of a sand wave area, Journal of Applied Geodesy, 3(doi:10.1515/JAG.2009.011), 97-120, 2009.

Dyer, K. R., and D. A. Huntley, The origin, classification and modelling of sand banks and ridges, Contintal Shelf Research, 19, 1285-1330, 1999.

Egiazaroff, I. V., Calculation of non-uniform sediment concentrations, Journal of the Hydraulics Division, ASCE, 91 (4), 225-248, 1965.

Flemming, B. W., The role of grain size, water depth and flow velocity as scaling factors controling the size of subaqueous dunes, in Proceedings of the first international workshop on marine sandwave dynamics, edited by A. Trenteseaux and T. Garlan, pp. 55-60, University of Lille, Lille, France, 2000.

Garcia, M., and G. Parker, Entrainment of bed sediment into suspension, Journal of Hydraulic Engineering, 117(4), 414-435, 1991.

Gerkema, T., A linear stability analysis of tidally generated sand waves, Journal of Fluid Mechanics, 417, 303-322, 2000. 
Gerritsen, H., J. G. Boon, T. v. d. Kaaij, and R. J. Vos, Integrated modelling of suspended matter in the North Sea, Estuarine, Coastal and Shelf Science, 53, 581-594, 2001.

Grasmeijer, B. T., T. Dolphin, C. Vincent, and M. G. Kleinhans, Suspended sand concentrations and transports in tidal flow with and without waves, in Sandpit, Sand transport and morphology of offshore sand mining pits, edited by L. C. Van Rijn, R. L. Soulsby, P. Hoekstra, and A. G. Davies, pp. U1-U13, Aqua Publications, 2005.

Green, M. O., C. E. Vincent, I. N. McCave, R. R. Dickson, J. M. Rees, and N. D. Pearson, Storm sediment transport: observations from the British North Sea shelf, Continental Shelf Research, 15(8), 889-912, 1995.

Green, M. O., R. G. Bell, T. J. Dolphin, and A. Swales, Silt and sand transport in a deep tidal channel of a large estuary (Manukau Harbour, New Zealand), Marine Geology, 163, $217-240,2000$.

Harris, P. T., Sand wave movement under tidal and wind-driven currents in a shallow marine environment: Adolphus Channel, northeastern Australia, Continental Shelf Research, 9(11), 981-1002, 1989.

Hennings, I., B. Lurin, C. Vernemmen, and U. Vanhessche, On the behaviour of tidal current directions due to the presence of submarine sand waves, Marine Geology, 169, 57-68, 2000.

Hirano, M., River bed degradation with armouring, trans. Jap. Soc. Civ. Eng., 3, 194-195, 1971.

Hulscher, S. J. M. H., Tidal-induced large-scale regular bed form patterns in a threedimensional shallow water model, Journal of Geophysical Research, 101, 727-744, 1996.

Hulscher, S. J. M. H., and G. M. Van den Brink, Comparison between predicted and observed sand waves and sand banks in the North Sea, Journal of Geophysical Research, 106(C5), 9327-9338, 2001.

Huthnance, J. M., On one mechanism forming linear sand banks, Estuarine, Coastal and Shelf Science, 14, 79-99, 1982.

Idier, D., A. Ehrhold, and T. Garlan, Morphodynamique d'une dune sous-marine du détroit du pas de Calais, Comptes Rendus Geoscience, 334, 1079-1085, 2002.

Kleinhans, M. G., and B. T. Grasmeijer, Bed load transport on the shoreface by currents and waves, Coastal Engineering, 53, 983-996, 2006.

Knaapen, M. A. F., Sandwave migration predictor based on shape information, Journal of Geophysical Research, 110(F04S11, doi:10.1029/2004JF000195), 2005.

Knaapen, M. A. F., and S. J. M. H. Hulscher, Regeneration of sand waves after dredging, Coastal Engineering, 46, 277-289, 2002.

Knaapen, M. A. F., S. J. M. H. Hulscher, and H. J. De Vriend, A new type of sea bed waves, Geophysical Research Letters, 28(7), 1323-1326, 2001.

Komarova, N. L., and S. J. M. H. Hulscher, Linear instability mechanisms for sand wave formation, Journal of Fluid Mechanics, 413, 219-246, 2000.

Le Bot, S., and A. Trentesaux, Types of internal structure and external morphology of submarine dunes under the influence of tide- and wind-driven processes (Dover Strait, northern France), Marine Geology, 211, 143-168, 2004.

Lesser, G. R., J. A. Roelvink, J. A. T. M. van Kester, and S. G. S, Development and validation of a three-dimensional morphological model, Coastal Engineering, 51, 883-915, 2004. 
McCave, I. N., Sand waves in the North Sea off the coast of Holland, Marine Geology, 10(3), 199-225, 1971.

Mei, C. C., The applied dynamics of ocean surface waves, Advanced Series on Ocean Engineering, vol. 1, World Scientific Publishing Co Pte Ltd, 1999.

Morelissen, R., S. J. M. H. Hulscher, M. A. F. Knaapen, A. A. Németh, and R. Bijker, Mathematical modelling of sand wave migration and the interaction with pipelines, Coastal Engineering, 48, 197-209, 2003.

Németh, A. A., Modelling offshore sand waves, Ph.D. thesis, University of Twente, The Netherlands, 2003.

Németh, A. A., S. J. M. H. Hulscher, and H. J. De Vriend, Modelling sand wave migration in shallow shelf seas, Continental Shelf Research, 22(18), 2795-2806, 2002.

Németh, A. A., S. J. M. H. Hulscher, and R. M. J. Van Damme, Simulating offshore sand waves, Coastal Engineering, 53, 265-275, 2006.

Németh, A. A., S. J. M. H. Hulscher, and R. M. J. Van Damme, Modelling offshore sand wave evolution, Continental Shelf Research, 27, 713-728, 2007.

Paarlberg, A. J., C. M. Dohmen-Janssen, S. J. M. H. Hulscher, J. Van den Berg, and P. Termes, Modelling morphodynamic evolution of river dunes, in River Flow 2006, edited by Ferreira, Alves, Leal, and Cardoso, pp. 969-978, Taylor \& Francis Group, London, 2006.

Paarlberg, A. J., C. M. Dohmen-Janssen, S. J. M. H. Hulscher, and P. Termes, A parameterization of flow separation over subaqueous dunes, Water Resources Research, 43(W12417, doi:10.1029/2006WR005425), 285-286, 2007.

Passchier, S., Distribution, geometry and orientation of megascale bedforms on the inner shelf, coast of Holland, 52-52n, based on echosounder data and side scan sonar (abstract), in Meeting on Marine Sand Wave and River Dune Dynamics 1-2 April 2004 (MARID), University of Twente, Enschede, the Netherlands, 2004.

Passchier, S., and M. G. Kleinhans, Observations of sand waves, megaripples, and hummocks in the Dutch coastal area and their relation to currents and combined flow conditions, Journal of Geophysical Research - Earth Surface, 110(F04S15, doi:10.1029/2004JF000215), 2005.

RIKZ, The wave climate site of the National Institute for Coastal and Marine Management /RIKZ, online available at www.golfklimaat.nl, 2004.

Roelvink, J. A., Coastal morphodynamic evolution techniques, Coastal Engineering, 53, 277$287,2006$.

Roos, P. C., Seabed pattern dynamics and offshore sand extraction, Ph.D. thesis, University of Twente, The Netherlands, 2004.

Roos, P. C., S. J. M. H. Hulscher, and M. A. F. Knaapen, The cross-sectional shape of tidal sandbanks: Modeling and observations, Journal of Geophysical Research, 109(F02003, doi:10.1029/2003JF000070), 2004.

Schüttenhelm, R. T. E., Grain-size variability and crest stability of a North Sea sand wave in space and time, Tech. Rep. TNO Report 02-219-B, Netherlands Institute of Applied Geosciences, Utrecht, The Netherlands, 2002.

Seminara, G., Effect of grain sorting on the formation of bed forms, Applied Mechanics Reviews, 48(9), 549-563, 1995. 
Smith, D. B., Bypassing of sand over sand waves and through a sand wave field in the central region of the southern North Sea, in Tide-influenced Sedimentary Environments and Facies, edited by P. L. de Boer, pp. 39-50, D. Reidel Publishing Company, 1988.

Smith, J. D., and S. R. McLean, Spatially averaged flow over a wavy surface, Journal of Geophysical Research, 12(82), 1735-1746, 1977.

Soulsby, R., Dynamics of marine sands, a manual for practical application, Thomas Telford, 1997.

Soulsby, R. L., Tidal-current boundary layers, in The Sea, edited by B. le Mehaute and D. M. Hanes, pp. 523-566, Ocean Engineering Science, John Wiley and Sons, New York, 1990.

Sterlini, F., S. J. H. M. Hulscher, and N. Dodd, Modelling the effect of surface waves on offshore sand waves, submitted, 2009a.

Sterlini, F., S. J. H. M. Hulscher, and D. M. Hanes, Simulating and understanding sand wave variation: A case study of the Golden Gate sand waves, Journal of Geophysical Research, 114 (F02007, doi:10.1029/2008JF000999), 2009b.

Swart, D. H., Offshore sediment transport and equilibrium beach profiles, Tech. Rep. 131, Delft Hydraulics, The Netherlands, 1974.

Terwindt, J. H. J., Sand waves in the southern bight of the North Sea, Marine Geology, 10, 51-67, 1971.

Tonnon, P. K., L. C. Van Rijn, and D. J. R. Walstra, The morphodynamic modelling of tidal sand waves on the shoreface, Coastal Engineering, 54, 279-296, 2007.

Trentesaux, A., A. Stolk, and S. Berne, Sedimentology and stratigraphy for a tidal sand bank in the southern North Sea, Marine Geology, 159, 253-272, 1999.

Tuijnder, A. P., J. S. Ribberink, and S. J. M. H. Hulscher, An experimental study into the geometry of supply-limited dunes, Sedimentology, submitted, 2009.

Van den Berg, J., Non-linear sand wave evolution, Ph.D. thesis, University of Twente, The Netherlands, 2007.

Van den Berg, J., and D. Van Damme, Sand wave simulations on large domains, in River, Coastal and Estuarine Morphodynamics:RCEM2005,Urbana, Illinois, USA, 4-7 October 2005, edited by G. Parker and M. H. Garcia, pp. 991-997, Taylor \& Francis, 2006.

Van der Mark, C. F., A. Blom, and S. J. M. H. Hulscher, Variability in bedform characteristics using flume and river data, in River, Coastal and Estuarine Morphodynamics: RCEM 2007, edited by C. M. Dohmen-Janssen and S. J. M. H. Hulscher, pp. 923-930, Taylor \& Francis Group, London, 2007.

Van der Meer, F. M., S. J. M. H. Hulscher, D. M. Hanes, and E. Elias, San Francisco Bay sand waves: modelling and observation, in River, Coastal and Estuarine Morphodynamics: RCEM 2007, edited by C. M. Dohmen-Janssen and S. J. M. H. Hulscher, Taylor \& Francis Group, London, 2007.

Van der Veen, H. H., S. J. M. H. Hulscher, and M. A. F. Knaapen, Grain size dependency in the occurence of sand waves, Ocean Dynamics, 56(3-4), 228-234, 2006.

Van der Veen, H. H., S. J. M. H. Hulscher, and B. Perez Lapena, Seabed morphodynamics due to offshore wind farms, in River, Coastal and Estuarine Morphodynamics: RCEM 2007, edited by C. M. Dohmen-Janssen and S. J. M. H. Hulscher, Taylor \& Francis Group, London, 2007. 
Van Dijk, A. G. P., and M. G. Kleinhans, Processes controlling the dynamics of compound sand waves in the North Sea, Netherlands, Journal of Geophysical Research - Earth Surface, 110(F04S10, doi:10.1029/2004JF000173), 2005.

van Dijk, T. A. G. P., P. J. P. Egberts, J. H. brouwer, and S. Van Heteren, The mobility of sand waves: an analysis of the behaviour and interference of bedforms from emperical data, in Proc. 8th Netherlands Aarwetenschappelijk Congres, Programme and Abstracts, Veldhoven, the Netherlands, 2006.

Van Oyen, T., and P. Blondeaux, Grain sorting effects on the formation of tidal sand waves, Journal of Fluid Mechanics, Accepted, 2009.

Van Rijn, L. C., Sediment transport, part ii: Suspended load transport, Journal of Hydraulic Engineering, 11(110), 1613-1641, 1984.

Van Rijn, L. C., Principles of sediment transport in rivers, estuaries and coastal seas, vol. I11, Aqua Publications, Amsterdam, 1993.

Van Rijn, L. C., and D. J. R. Walstra, Modelling of sand transport in DELFT3D-ONLINE, WL-Delft Hydraulics, Delft, jebbe heeft hem, 2003.

Veen, J. v., Sand waves in the Southern North Sea, International Hydrographic Review, 12, 21-29, 1935.

Wientjes, I. G. M., Grain size sorting over sand waves, CEESM research report 2006R004/WEM-005, University of Twente, The Netherlands, 2006.

Wilkens, J., Sand waves and possible related characteristics, Tech. rep., Report for Alkyon Hydraulic Consultancy and Research, 1997.

Winter, C., Modelling current patterns on large compound bedforms, in 31st International Conference on Coastal Engineering, Hamburg, Germany, 2008.

Winter, C., G. Vittori, V. B. Ernstsen, and J. Bartholdy, On the superimposition of bed forms in a tidal channel, in Marine Sandwave and River Dune Dynamics III: MARID 2008, edited by D. R. Parsons, T. Garlan, and J. L. Best, pp. 337-344, 2008.

WL|Delft Hydraulics, Delft3D-FLOW; simulation of multi-dimensional hydrodynamic flows and transport phenomena, including sediments, User manual Delft3D version 3.13, WL|Delft Hydraulics, The Netherlands, 2006.

Zyserman, J. A., and J. Fredsoe, Data-analysis of bed concentration of suspended sediment, Journal of Hydraulic Engineering, 120(9), 1021-1042, 1994. 


\section{About the author}

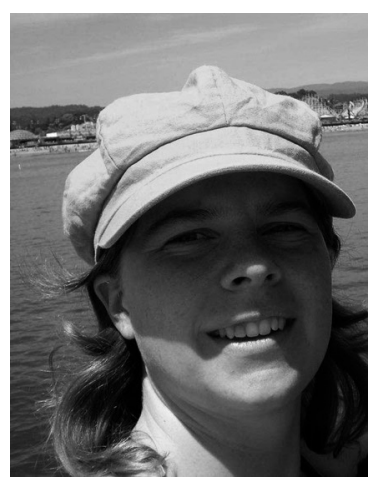

Fenneke Sterlini (born Van der Meer, 26-07-1980) started her PhD at the Water and Management department of the University of Twente in September 2004. Before that, she finished her secondary school at the Stedelijke Scholengemeenschap in Zutphen, her BSc (soil, water and atmosphere) and MSc (hydrology) at the Wageningen University, and a year of philosophy at the Radboud University in Nijmegen. She is currently working as a PostDoc and Assistant Professor at the Water and Management department of the University of Twente.

Besides the fields of sand waves and modelling, described in this thesis, her interests lie in the Wadden Sea, ecology, philosophy, cooking, playing the piano and walking. 